\title{
A ERA DOS GAMES NA SOCIEDADE DA ESCOLHA
}

\author{
Tese apresentada à Área de \\ Concentração Meios e Processos \\ Audiovisuais da Escola de \\ Comunicações e Artes da \\ Universidade de São Paulo, como \\ exigência parcial para a obtenção \\ do Título de Doutor em Ciências da \\ Comunicação, sob a orientação do \\ Prof. Dr. Mauro Wilton de Sousa.
}

São Paulo, agosto de 2014 
BANCA EXAMINADORA 


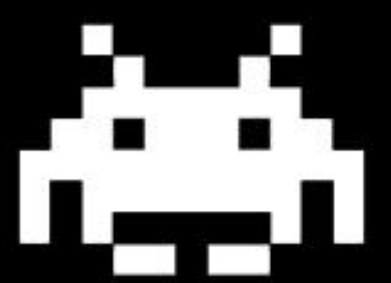

PRESS STFRT 
DEDICATÓRIA

Para Tati, com amor! 


\section{AGRADECIMENTOS}

Ao meu querido professor, Mauro Wilton de Sousa, que com paciência, carinho e amizade sempre me orientou em meus caminhos.

Aos meus pais José Antonio e Anete, pelo incentivo constante de uma vida inteira. E aos pais de meus pais, José, Hélia, Hermógenes e Antonieta. Vocês vivem em mim.

À minha amada esposa Tatiana, incrível companheira de aventuras.

À boa e velha ECA, na figura de seus muitos funcionários, alunos e professores. Com suas qualidades e idiossincrasias, não deixará nunca, por vários motivos, de ser muito significativa em minha vida.

E a todo o meu povo, parentes e amigos: os daqui e os de lá! Muito obrigado! 
Somos os peões deste jogo do xadrez

que Deus trama. Ele nos move, lança-nos

uns contra os outros, nos desloca, e depois

nos recolhe, um a um, à Caixa do Nada.

Omar Khayyam 
RESUMO:

Os jogos eletrônicos, ampliados em suas possibilidades pela tecnologia e alinhados com o modo de ser contemporâneo, experimentam um crescimento vertiginoso nas três últimas décadas. Este trabalho sustenta que a atual síntese entre jogos, tecnologia e sociedade estabeleceu as condições para a deflagração de uma "Era dos Games".

Esse cenário se caracteriza não apenas pelo papel preponderante dos jogos eletrônicos como uma das principais formas de entretenimento, mas, também, pela internalização da lógica de jogo em diversas outras instâncias da dinâmica contemporânea. Em seu patamar mais alto, a "Era dos Games" é a constatação de que o uso massivo dos jogos eletrônicos promove, em seu enraizamento no corpo social, um rebalanceamento na luta travada entre diversas retóricas, que lutam pela hegemonia explicativa do que seja o jogo e o jogar na contemporaneidade.

Palavras-Chave: games; comunicação; tecnologia; filosofia; jogo 


\section{ABSTRACT:}

The electronic games, expanded in its own possibilities thanks to its alliance with technology and aligned with the contemporary way of being, experienced an outstanding growth over the past three decades. This work argues that the current synthesis between games, technology and society established the conditions for the outbreak of an "Age of Games".

This scenario is characterized not only by the dominant role of electronic games as a major form of entertainment but also for the internalization of game logic in several other instances of contemporary dynamics. The "Age of Games", in its last phase, is the assumption that the massive use of electronic games, in its rooting in the social body, is rebalancing the struggle waged nowadays between different rhetorics, each fighting for explanatory hegemony of what is play in contemporaneity.

Keywords: games; communication; technology; philosophy; play 


\section{Capítulo I: Jogos Eletrônicos no Cenário Contemporâneo}

1.1. A Visibilidade Social dos Jogos Eletrônicos a partir da Mídia - pg. 16

1.2. Número de Jogadores ao Redor do Mundo - pg. 23

1.3. Perfil dos Jogadores nos EUA e na Grã-Bretanha - pg. 24 1.4. A Indústria de Games no Mundo - pg. 27 1.5. Brasil: os Gamers e o Mercado - pg. 29

\section{Capítulo II: As Múltiplas Faces do Jogo}

2.1. As Múltiplas Faces do Jogo - pg. 31

2.2. Em Busca de Uma Definição de Jogo - pg. 45 2.3. Jogo como Linguagem - pg. 47

2.4. Jogo como Meio de Comunicação de Massa - pg. 50 2.5. O Modus Operandi do Jogo - pg. 53 2.6. 0 que o Jogo Significa para os Jogadores - pg. 60 2.7. Jogo e Diversão (Fun) - pg. 62 2.8. Jogo e Fantasia - pg. 67 2.9. Jogo e Onipotência - pg. 73 2.10. Jogos Eletrônicos no Contexto Maior dos Jogos - pg. 77

\section{Capítulo III: As Tecnologias da Escolha}

3.1. As TICs (Tecnologias de Informação e Comunicação) e o Jogo - pg. 79 
3.3. Característica Participativa e Diversão (Fun) - pg. 84

3.4. Característica Espacial e o Jogo - pg. 90

3.5. Característica Enciclopédica e o Jogo - pg. 96

\section{Capítulo IV: A Sociedade da Escolha}

4.1. A Sociedade da Escolha - pg. 103

4.2. Consumismo e Escolha - pg. 105

4.3. Consumismo e Diversão - pg. 109

4.4. Consumismo e Fantasia - pg. 111

4.5. Consumismo e Onipotência - pg. 113

4.6. Identidade e Escolha - pg. 115

4.7. Identidade e Diversão - pg. 125

4.8. Identidade e Fantasia - pg. 129

4.9. Identidade e Onipotência - pg. 134

Capítulo V: Conclusão

5.1. Conclusão - pg. 139

Bonus Phase

6.1. Games: Comunicação Lúdica de Massa - pg. 145

6.2. Games: Ideal Contemporâneo do Lúdico - pg. 149

6.3. Retóricas do Jogo em Reordenação - pg. 153

Referências

Referências - pg. 156 


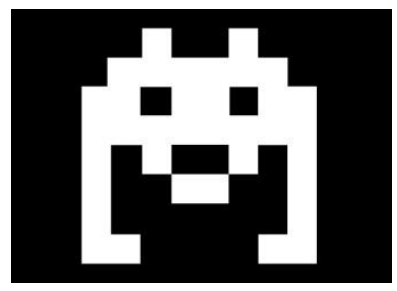

\section{INTRODUÇÃO}

Nas últimas três décadas, os jogos eletrônicos, popularmente conhecidos como games ${ }^{1}$, ampliam gradativamente seu espaço como uma das expressões culturais mais efervescentes da contemporaneidade.

Envolvidos diretamente com a revolução digital, os jogos reinventaramse em sua modalidade eletrônica, ampliando suas capacidades de maneira considerável (TURKLE, 1995).

Como produto, os jogos eletrônicos constituem hoje uma das mais pujantes indústrias culturais do planeta (PRICEWATERHOUSECOOPERS, 2011).

Como entretenimento, preenchem cada vez mais o tempo livre dos indivíduos, muitas vezes suplantando outros hábitos de diversão de massa já estabelecidos (BBC, 2005) (PEW INTERNET \& AMERICAN LIFE PROJECT, 2008) (ESA, 2012).

1 Nota do Autor: neste trabalho, os termos jogos eletrônicos e games serão utilizados como sinônimos. 
Graças à sua nova expressão digital, tornaram-se ubíquos na mesma proporção em que a informatização espraiou-se pelas mais diferentes situações do cotidiano (MIÈGE, 2009, p. 140). Para além dos computadores e consoles, os jogos tornaram-se presentes também em celulares, relógios, tablets e os mais variados aparelhos eletrônicos, o que os coloca, em última instância, como possibilidades para todas as horas.

Nas cidades esvaziadas de espaços públicos e com espaços privados reduzidos, os jovens encontraram nos jogos eletrônicos um espaço amplo de brincadeira solitária e também de interação com seus amigos e colegas. Nas relações familiares, os jogos assumiram o papel de ponte através da qual diferentes gerações dialogam e se entretêm. Nas relações amorosas, são um dos sinais de intimidade. Nas relações interpessoais, posicionam-se como um parâmetro de modernidade e inclusão tanto quanto de exclusão.

Em diferentes momentos da vida cotidiana - a solidão nos deslocamentos pelas extensas metrópoles, nos diferentes eventos sociais nos quais os indivíduos se sentem deslocados, dos filhos diante de pais sem paciência para os interesses da infância, dos adolescentes em busca de desafios e liberdade, dos despossuídos e desempregados em busca de escape, dos idosos em busca de vida - os jogos eletrônicos tornaram-se um calmante, um elixir, um bálsamo, um oásis de diversão e alegria para as incompletudes e angústias da vida.

Na política, na imprensa, na educação, na publicidade, na Academia, na esfera das relações familiares, na expressão da identidade grupal, na própria seara da identidade pessoal - a cultura dos jogos eletrônicos exerce influência sobre os mais diversos eixos nos quais transita a cultura contemporânea.

Dada a amplitude de uso dos jogos eletrônicos e dada a relevância com que isso se apresenta no corpo social, sem limitar-se a classes sociais, gerações e campos de interesse específicos, generalizando-se no uso cotidiano, operando como termômetro de inserção cultural, emprestando sua lógica de funcionamento para outras esferas da vida, seria razoável afirmar que os jogos 
eletrônicos tornaram-se um elemento decisivo na construção da socialidade contemporânea.

Enfim, por que os jogos eletrônicos adquiriram tanta importância no cenário contemporâneo? Quais seriam os valores, cultivados dentro desse cenário social, que explicariam essa ascensão dos games? Em que medida a dinâmica da sociedade atual responde pelo uso intensivo dos jogos eletrônicos?

A hipótese deste trabalho é que a ascensão dos jogos eletrônicos é fruto de uma profunda e inédita síntese entre três elementos: características da dinâmica social atual que se associam a especificidades dos jogos e ao modus operandi das TICs (Tecnologias de Informação e Comunicação) (MIÈGE, 2009, p. 10). A afinidade entre esses três elementos constituiria o fator central explicativo para a importância adquirida pelos jogos eletrônicos na contemporaneidade.

Como consequência, os jogos caminhariam, pois, para tornar-se não apenas uma forma cultural de entretenimento hegemônica dos tempos atuais, mas também meio de comunicação através do qual, pelo lúdico, a sociedade se enxergaria, se comunicaria e se legitimaria.

Essa proeminência seria responsável, em última instância, por uma alteração da própria concepção de jogo sustentada pelo corpo social. O impacto geral provocado por essas mudanças é o que caracterizaria a chamada "Era dos Games".

Em relação à estrutura do trabalho, a primeira variável, concernente aos jogos, será dividida em dois capítulos. O primeiro capítulo tratará da dimensão ocupada pelos jogos eletrônicos no cenário contemporâneo. Embora não seja um capítulo de análise, ele é importante porque oferece uma dimensão aproximada da extensão com que os jogos se infiltram no corpo social. Para orientar essa primeira aproximação, serão selecionadas:

a) Reportagens e artigos na imprensa, com diversas posições a respeito das práticas relacionadas aos jogos eletrônicos. 
b) Dados quantitativos a respeito do número de jogadores no mundo e no Brasil.

c) Pesquisas que apontem o perfil dos jogadores e hábitos de uso (faixa etária, gênero, nível sócio-econômico).

d) Dados sobre o desenvolvimento da indústria de jogos eletrônicos no mundo.

O segundo capítulo procura dar conta das muitas explicações que cercam o enigmático fenômeno do jogo. Além disso, será examinado com mais detalhe o modus operandi particular encontrado no jogo, diferente de outras tecnologias e expressões desenvolvidas pelo Homem. Afinal, se os jogos, operando dentro de um suporte eletrônico, são ferramentas que de alguma forma seduzem as pessoas, a explicação para esse engajamento está, antes de tudo, na própria maneira pela qual os jogos, mesmo antes do advento de suas versões eletrônicas, capturam a imaginação humana desde a aurora dos tempos. Por isso, uma análise sobre as propriedades do jogar compõe o segundo capítulo da tese.

O terceiro capítulo é voltado para a análise da razão estruturante oferecida pelas TICs (Tecnologias de Informação e Comunicação) (MIÈGE, 2009, p. 10). Essas tecnologias possuem também certas propriedades de uso que influenciam as outras duas variáveis. No caso dos jogos, há uma consonância, uma ampliação e um enriquecimento das suas qualidades impulsionadas pela conjuntura digital. Um exame mais detalhado sobre a influência das condições tecnológicas dentro desse cenário é o objetivo deste capítulo.

O quarto capítulo diz respeito ao último eixo desse tripé: os valores presentes no corpo social, que de algum modo encontram afinidade com as características do jogo eletrônico. Pois, se esse gênero cultural - híbrido de jogo e tecnologia - vem alcançando magnitude e importância, é porque ele também satisfaz e é reflexo da sociedade que o alimenta, que o molda. 
O quinto capítulo abriga a conclusão do trabalho. Aqui, pretende-se defender a ideia de que o impacto promovido pelo uso intensivo dos jogos eletrônicos reverbera em diversos níveis dentro do extrato social. O peso total dessa ancoragem dos games no tecido social inauguraria a chamada "Era dos Games". 


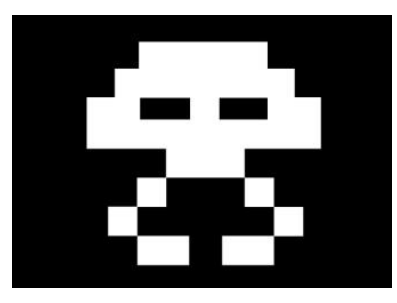

CAPÍTULO I:

\section{JOGOS ELETRÔNICOS NO CENÁRIO CONTEMPORÂNEO}

\section{1. - A VISIBILIDADE SOCIAL DOS JOGOS ELETRÔNICOS A PARTIR DA MÍDIA}

As notícias ligadas ao universo dos jogos - particularmente os jogos eletrônicos - têm merecido um espaço cada vez maior e mais frequente dentro de diversos veículos de comunicação. Jornais, revistas, noticiários televisivos, programas de rádio e diversos sites veiculam regularmente matérias que expõem os humores de diferentes grupos em relação aos games. Nesta introdução, serão indicados alguns títulos de matérias veiculadas na mídia, divididas em cinco grupos distintos.

O primeiro grupo contém matérias que ainda expressam, de uma forma negativa, o estranhamento do corpo social diante das práticas relacionadas aos jogos eletrônicos. Ora são reportagens sobre a relação entre jogos e violência ("Jogador esfaqueia homem que matou seu personagem em game") (FOLHA DE SÃO PAULO, 2010), ora matérias sobre jogos e comportamento social ("Grupo cristão promove boicote a jogos com personagens gays") (FOLHA DE SÃO PAULO, 2012), ora pautas que expõem a conduta esdrúxula de certos 
tipos de jogadores ("Japonês se casa com personagem de videogame") (G1, 2009), ou ainda alertas sobre o efeito nocivo dos jogos ("Jogos violentos podem alterar funções cerebrais") (ESTADÃO, 2011).

Em comum, um tratamento jocoso ou sensacionalista, buscando o inusitado, o bizarro, o estranho. As práticas relacionadas aos jogos aparecem aqui como objeto de riso, de escárnio, de indignação moral ou ainda como um sintoma a ser medicado. Nesse grupo de matérias, os jogadores são vistos como pessoas praticamente doentes.

Esse tipo de atitude hostil em relação aos jogos, embora expresse uma recusa, não deixa de traduzir também uma aproximação e uma delimitação desse campo simbólico, na medida em que, ainda que pelo viés negativo, reconhecem os jogos eletrônicos como um vetor social.

No segundo grupo, no outro lado do espectro, o estranhamento para com os jogos toma a forma de um certo fascínio, de uma rendição aos games. $\mathrm{Na}$ medida em que aumentam sua popularidade, os jogos são vistos como ferramentas capazes de levar seus praticantes a um melhor patamar em outros aspectos da vida.

Nesse tipo de matérias, a característica mais marcante é a atribuição de pretensas qualidades aos jogos eletrônicos, qualidades essas que operam como um aval para seu uso no mundo cotidiano. Um exemplo dessa nova panacéia universal encontra-se na revista Veja "Games para os Avós" (VEJA, 2012), da qual se reproduz aqui o lead: "Foi-se o tempo em que a diversão do vovô era jogar biriba com os amigos. Cada vez mais familiarizados com a tecnologia, os idosos que trocam o baralho pelo videogame só têm a ganhar".

Talvez os idosos tenham realmente a ganhar, não por jogarem video game em vez de biriba, uma vez que, em ambos os casos, as faculdades cognitivas são igualmente estimuladas. Mas sim pelo fato de que, ao aderirem ao uso dos jogos eletrônicos, os idosos são guindados da desconfortável posição de "velho ultrapassado" para a muito mais integrada e confortável postura de "jovem de espírito". 
Isso para não falar da integração proporcionada pelo consumo. Ao aspirar por um determinado console, ao escolher determinados títulos, ao participar do ritual de comparações entre produtos, o idoso participa de uma lógica contemporânea.

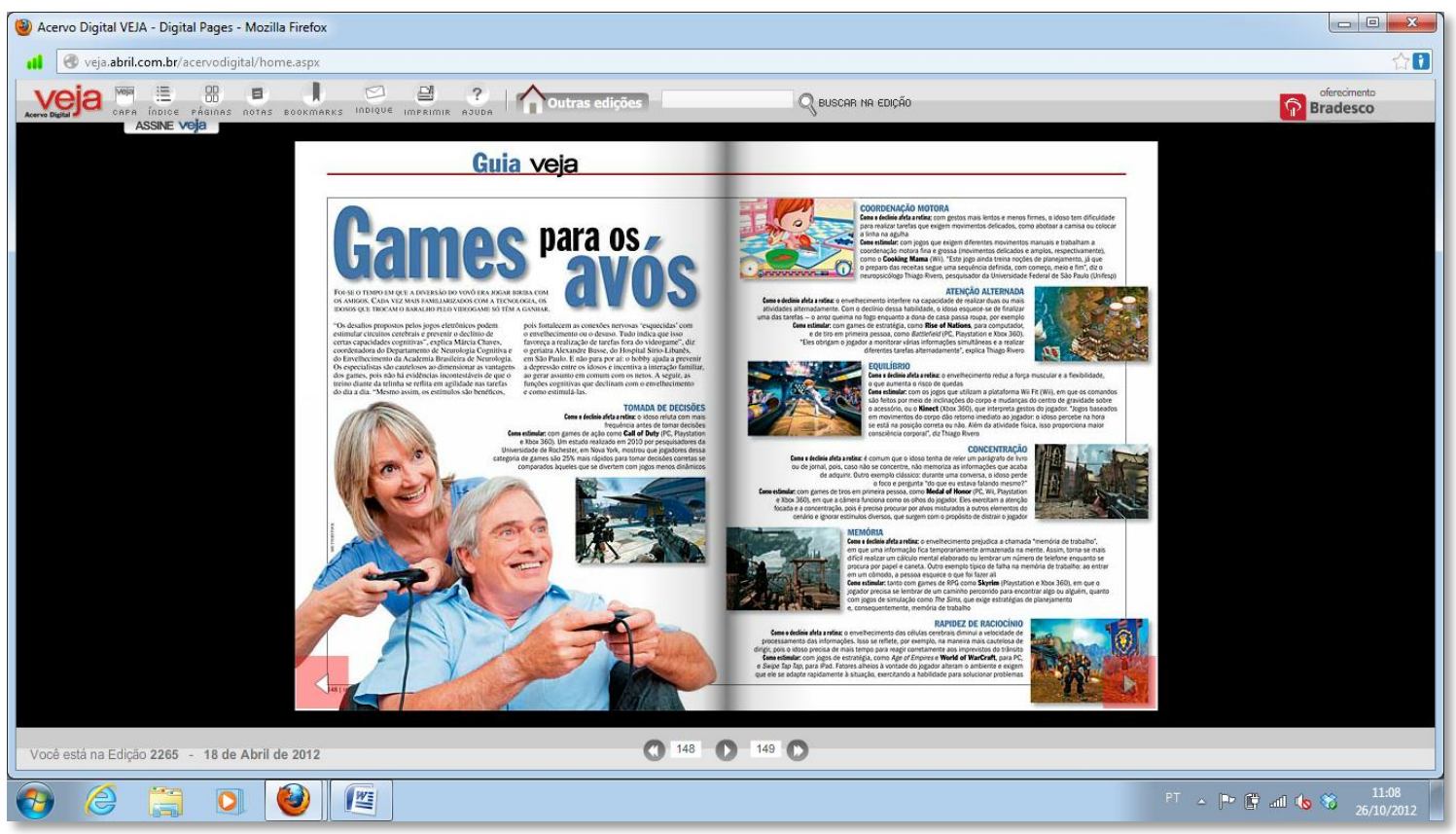

Figura 1: "Games para os Avós". Revista VEJA.

Os jogos, dentro desta segunda perspectiva, ajudam a melhorar os sentidos ("Pesquisa: jogos em primeira pessoa melhoram atenção e visão dos usuários") (OLHAR DIGITAL, 2012), o desempenho mental ("Jogos de ação melhoram o desempenho do cérebro") (GAMES UNIVERSE BLOG, 2012), a coordenação motora e até mesmo as boas maneiras ("Games melhoram coordenação motora e boas maneiras das crianças") (FOLHA DE SÃO PAULO, 2004).

No terceiro grupo, há as matérias que, também dentro da linha do fascínio, vislumbram a importância dos games a partir daquilo que parece ser um dos maiores pontos de legitimação para esta sociedade: jogos como negócio, como oportunidade de ganhar dinheiro. Dentro dessa lógica, os games 
são levados em consideração principalmente porque são a expressão de uma nova e pujante indústria cultural.

A matéria publicada pela revista Época, "A Maior Diversão da Terra" (ÉPOCA, 2012), por exemplo, propõe em seu lead uma relação causal entre o desenvolvimento da indústria de games e a disseminação de práticas sociais relacionadas ao jogar: "Depois de se transformar na forma mais lucrativa de entretenimento, os games estão prestes a mudar a maneira como nos relacionamos com a realidade."

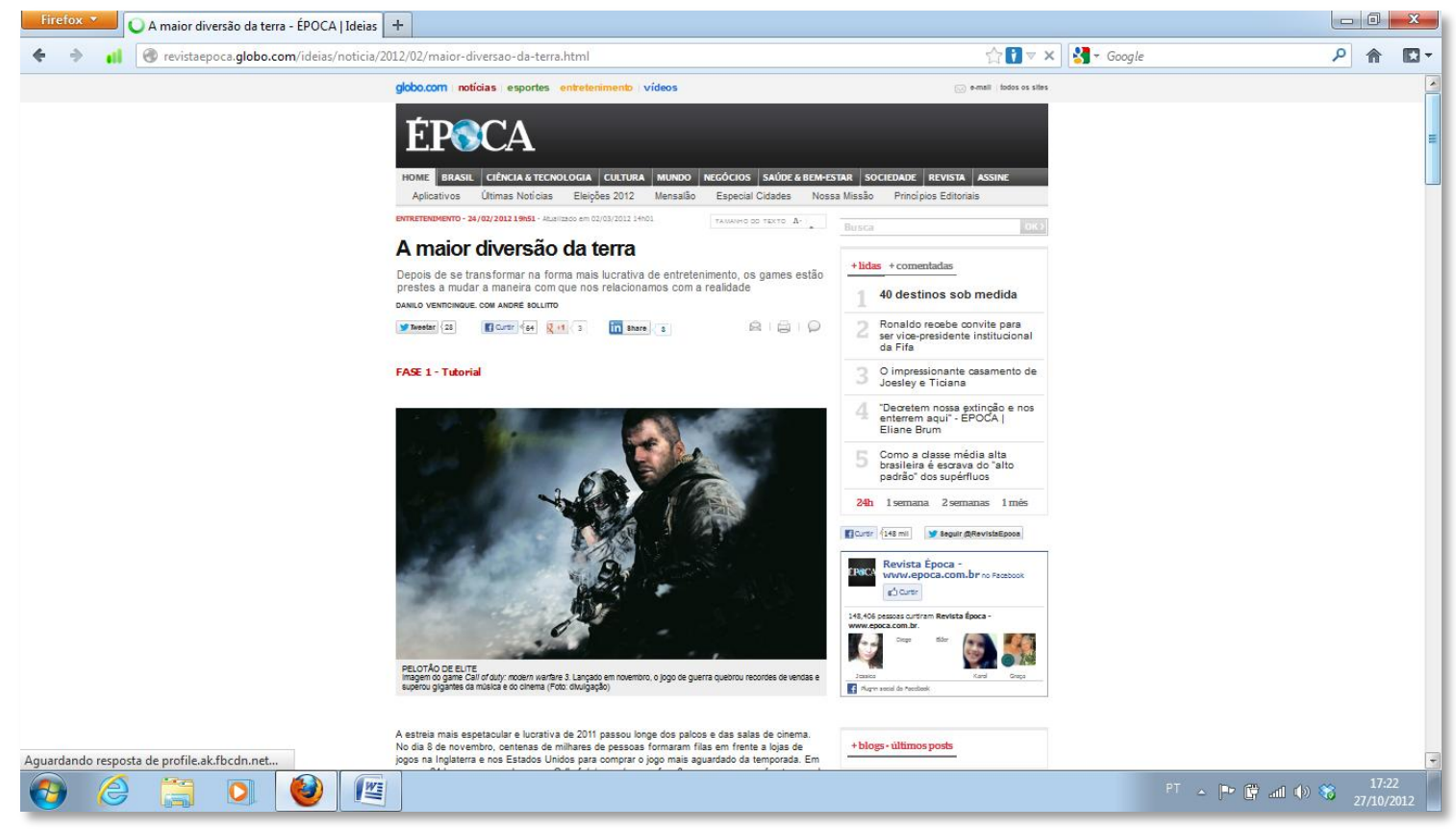

Figura 2: "A Maior Diversão da Terra". Revista ÉPOCA

De fato, o amadurecimento cada vez maior da indústria dos games a coloca, hoje, em pé de igualdade com outras formas de expressão cultural mercantilizadas, como a música, os seriados de TV e os filmes. Jogar não deixa de ser uma expressão de um determinado tipo de consumo. Porém, existem outros elementos explicativos para a popularização dos games que ultrapassam a lógica de mercado. A popularização dos jogos é beneficiada pela indústria, mas não é tributária apenas dela. 
De qualquer modo, o que vale ressaltar é que o fato dos games serem tratados como negócio, já é, em si, também, uma maneira de propor uma legitimação dos jogos dentro do campo de valores vigentes.

Exemplos desse tipo de aproximação podem ser encontrados em matérias veiculadas no Terra ("Mercado Brasileiro de Games vira oportunidade de negócios") (G1, 2012), na revista Exame ("A Vez dos Advergames na Internet") (EXAME, 2012), na revista Pequenas Empresas \& Grandes Negócios ("Mercado de Games tem potencial para faturar R\$ 3 bilhões") (PEGN, 2011), etc. .

No quarto grupo, alinham-se reportagens que apontam para a disseminação do uso dos jogos eletrônicos em diversas funções e atividades humanas que não o jogar. Nesse grupo de matérias, a racional está na valorização dos jogos não pela diversão que se obtém jogando o jogo em si, mas sim como uma maneira nova, divertida, interativa, enfim, lúdica de lidar com assuntos ou tarefas do cotidiano considerados áridos, complexos ou tediosos. O jogo torna-se instrumento para outra coisa que não o jogo em si.

Assim, os jogos são apresentados como solução para treinamentos corporativos ("Empresas em Jogo") (PEGN, não informado), para procedimentos médicos ("Os Games da Saúde") (ISTOÉ, 2012), para o ensino de matérias na escola ("Game 'Conflitos Globais' tenta quebrar paradigma e colocar jogos na escola") (G1, 2010), para ajudar a escolher profissões ("Jogo Empresarial ajuda a escolher profissões") (ESTADÃO, 2012), etc..

Essas matérias descrevem um gênero de jogos apelidado, em inglês, como serious games, cuja principal função é ajudar os participantes a absorver conteúdos e conceitos diversos. Como o próprio nome já diz, este gênero traz embutida a percepção dos jogos como algo originalmente não-sério, que é tornado sério (produtivo) ao ser usado para a resolução de uma tarefa prática. É uma visão ainda bastante angulada pelo entendimento do jogo como algo oposto ao trabalho. 
Mesmo na publicidade, a ânsia de utilizar a dinâmica dos jogos em benefício de outra coisa que não o jogo pode ser mensurada pelas diversas matérias que tratam dos advergames e os processos de Gamification. Os advergames como uma nova maneira de se trabalhar questões como branding ("Saiba como os Advergames podem promover uma marca") (INFO EXAME, 2012), ou ainda como meio ideal para o lançamento de produtos ("O Jogo Rentável dos Games") (ISTOÉ DINHEIRO, 2008); e a Gamification como uma maneira de trabalhar estímulos-recompensas, princípio vital para a indústria da publicidade ("O que é 'Gamification"') (EXAME, 2011).

Finalmente, o quinto grupo é composto pelas matérias que trabalham os jogos dentro de uma ótica positiva, alavancadas por essa nova indústria cultural. São análises de jogos, reportagens sobre os novos lançamentos da temporada, avaliação de gadgets e até mesmo matérias de viés comportamental voltadas para os insiders, para os praticantes, para as pessoas que jogam regularmente.

O tratamento dado aos jogos é o mesmo que um veículo especializado em filmes dá aos lançamentos da temporada, ou que um site sobre futebol oferece em relação aos jogos da rodada. Traduz uma postura de assimilação em relação aos games, enquadrando este gênero cultural na longa e variada cadeia de interesses das pessoas. Geralmente, essas notícias ainda estão restritas aos cadernos de informática e aos sites especializados ("Novos games tornam Playstation 4 e Xbox One mais atraentes") (FOLHA DE SÃO PAULO, 2014).

Ao analisar esses grupos de notícias, percebe-se em primeiro lugar que esse assunto tornou-se significativo para uma parcela maior da sociedade. Jogar - e é isso que essas matérias demonstram - tornou-se, em variados graus e por diversas razões, uma atividade merecedora de crescente curiosidade. Os jogos eletrônicos deixaram de ser uma atividade de interesse restrito e tornaram-se um assunto de interesse geral. 
Em segundo lugar, chama a atenção a variedade de aproximações encontradas nas notícias. Se os games são percebidos pela mídia como um novo objeto dentro do cenário social, sua apreciação está longe de ser consensual. Pelo contrário, assiste-se a uma relação ainda ambígua e paradoxal entre a mídia e os games. Como se essa cacofonia de posicionamentos diante dos games expressasse um vaivém, uma hesitação, um revoluteio, não apenas da mídia, mas sim da sociedade.

A julgar pelos discursos das matérias, os games são desejados porque simbolizam uma nova fonte de prazer e entretenimento, porque trazem o lúdico à vida das pessoas, porque integram, porque trazem refúgio ao stress, porque suavizam processos que de outro modo seriam áridos, porque podem ser uma fonte de lucro.

Mas, ao mesmo tempo, recusam-se os games porque eles desviam as pessoas perigosamente da realidade, porque parecem despertar comportamentos doentios, porque são alienantes, porque incitam à violência, porque são improdutivos e porque parecem ser perigosamente epidêmicos. Os pais exemplificam bem essa dualidade: não querem que as crianças sejam escravizadas pelos games. Porém, no Natal, lhes oferecem novos consoles.

Essa dubiedade com que a sociedade lida com os jogos eletrônicos vaza pelos canais midiáticos e epitomiza o embate de uma sociedade que oscila entre diferentes aproximações e julgamentos. Uma sociedade que, por um lado, usufrui do jogo, mas que ao mesmo tempo o rejeita, o estranha, ainda o toma como frívolo.

Isso é ainda mais verdade quando se considera o jogo como a grande nêmesis de uma sociedade ainda fundada no trabalho e em certos valores morais-religiosos. Neste sentido, a emergência dos jogos eletrônicos é a pontade-lança que reacende uma luta intestina entre diversas concepções a respeito do jogo, cujas origens se perdem no tempo. 


\section{2. - NÚMERO DE JOGADORES AO REDOR DO MUNDO}

McGonigal (MCGONICAL, 2011) tenta estimar a comunidade gamer ao redor do mundo. Note-se que, por gamers, entende-se desde aqueles que possuem um console até aqueles que utilizam jogos sociais via internet, passando por usuários dos clássicos jogos de computador até os que se divertem em dispositivos móveis, como celulares e tablets.

Apenas nos Estados Unidos existem 183 milhões de jogadores ativos [...]. Globalmente, a comunidade gamer online - incluindo console, PC e jogos para celular - contabiliza mais de 4 milhões de jogadores no Oriente Médio, 10 milhões na Rússia, 105 milhões na Índia, 10 milhões no Vietnã, 10 milhões no México, 13 milhões nas Américas Central e do Sul, 15 milhões na Austrália, 17 milhões na Coréia do Sul, 100 milhões na Europa e 200 milhões na China (MCGONICAL, 2011, p. 3).

Aceitando os números propostos por McGonical, chega-se a uma população de quase 670 milhões de jogadores ao redor do planeta, um número nada desprezível.

Nos Estados Unidos, pesquisa realizada em 2011 pelo NPD Group estimou em 211,5 milhões o número de gamers norte-americanos (NPD GROUP, 2012), um número ainda maior do que o oferecido por McGonigal (183 milhões). Pesquisa da holandesa Newzoo, especializada na aferição do mercado de games ao redor do mundo, reportou um total de 157 milhões de jogadores ativos nos EUA em 2012 (NEWZOO, 2012), um número mais conservador. Ou seja, a julgar por estas três fontes, o número de gamers norte-americanos oscila de 150 milhões a 200 milhões, num universo de 319 milhões de habitantes (UNITED STATES CENSUS BUREAU, 2013).

Do mesmo modo, as estimativas se estendem para outros territórios do mundo, com números muitas vezes conflitantes. Enquanto McGonical estima em 4 milhões os gamers no Oriente Médio, a Newzoo coloca, apenas na Turquia, um número próximo de 30 milhões de jogadores. Na Rússia, McGonical projeta 10 milhões de jogadores, enquanto pesquisa realizada pela Viximo (VIXIMO, 2012), plataforma especializada em social games, contabiliza 
35 milhões de jogadores e levantamento conduzido pela Newzoo aponta 38 milhões de gamers russos.

De qualquer modo, quer estime-se 700 milhões de jogadores, numa estimativa conservadora, ou quer projete-se 1 bilhão de jogadores no planeta, numa estimativa mais ousada, fica evidente que este é um fenômeno massivo que, quer pela população de praticantes, quer pela distribuição ao redor do mundo, não pode deixar de ser examinado em mais detalhe.

\section{3 - PERFIL DOS JOGADORES NOS EUA E GRÃ-BRETANHA}

Os Estados Unidos e a Grã-Bretanha são os países onde os jogos eletrônicos alcançam hoje sua expressão mais vigorosa. São mercados maduros, lugares onde diversas práticas associadas aos jogos já estão enraizadas. Devido a isso, as pesquisas sobre esse tema neles desenvolvidas não apenas são mais fidedignas, como também servem como parâmetro para estudos sobre o assunto.

Tomou-se como base para a análise as seguintes pesquisas: "Adults and Video Games" (PEW INTERNET \& AMERICAN LIFE PROJECT, 2008) e "Teens, Video Games and Civics" (PEW INTERNET \& AMERICAN LIFE PROJECT, 2008); "BBC UK Games Research" (BBC, 2005), "Essential Facts About the Computer and Video Game Industry - Sales, Demographic and Usage Data" da ESA (Entertainment Software Association) (ESA, 2012).

A primeira constatação importante diz respeito ao número total de jogadores dentro da população total. O Pew Institute afirma que $53 \%$ dos americanos com mais de 18 anos jogam videogames, dos quais $21 \%$ jogam todos os dias ou quase todos os dias. De modo similar, pesquisa da BBC, reportando sobre o público do Reino Unido, afirma que 59\% da população pratica algum tipo de jogo eletrônico, seja ele num console, num PC, na TV interativa, num portátil ou no celular. 
Um segundo corte demonstra que, em todas as pesquisas, há um componente geracional. A ESA aponta 30 anos como a idade média do gamer, enquanto a BBC calcula em 28 anos a idade média (lembrando que entre as duas pesquisas existe uma diferença de sete anos. Certamente, a idade média sugerida pela $\mathrm{BBC}$, a pesquisa mais antiga, já se elevou).

E em todas as pesquisas, quanto mais jovem, maior a taxa de uso dos games. No Reino Unido, virtualmente $100 \%$ da população de 6-10 anos é praticante. A taxa cai para $97 \%$ na faixa de $11-15$ anos, $82 \%$ na de $16-24$ anos; $65 \%$ na de 25-35 anos; $51 \%$ na de $36-50$ anos e $18 \%$ na de 51-65 anos. Os dados do Pew Institute não são diferentes: confirmam os mesmos $97 \%$ de uso para a faixa de 11 a 15 anos. Na introdução do relatório, pesquisadores do Pew afirmam:

Jogar games é algo universal, virtualmente todos os adolescentes jogam games e ao menos metade jogam todos os dias. Experiências com games são diversas, com as categorias mais populares recaindo nos gêneros de corrida, puzzle, esportes, ação e aventura. Jogar também é social, com muitos adolescentes jogando games uns com os outros ao menos parte do tempo e incorporando vários aspectos de civilidade e vida política. (PEW INTERNET \& AMERICAN LIFE PROJECT, 2008)

Entretanto, ainda que eventualmente geracional, há alguns dados que chamam a atenção e que desmontam a ideia de que jogos eletrônicos são um privilégio exclusivo dos jovens.

De acordo com o Pew Institute, o grupo dos americanos com mais de 65 anos que jogam games é, proporcionalmente, mais compromissado com o jogo que os extratos mais jovens: quase um terço dessa população joga todos os dias, contra apenas $20 \%$ dos jovens que jogam diariamente.

Uma terceira angulação é a que diz respeito ao gênero dos participantes. Contrariando a percepção de que o jogo é uma atividade eminentemente masculina, a pesquisa da ESA, de 2012, reporta uma proporção de $53 \%$ de homens e $47 \%$ de mulheres gamers. Estes dados são confirmados pela pesquisa da $\mathrm{BBC}$, de 2005, que classifica os gamers entre $55 \%$ homens e $45 \%$ 
mulheres. Mais ainda, de acordo com a ESA, mulheres de 18 ou mais representam uma parte significativamente maior da população gamer (30\%) do que garotos de 17 ou menos (18\%).

Em relação à educação, a pesquisa Pew indica que, quanto maior o grau de instrução, maior a porcentagem de praticantes. Dos jogadores com 18 anos ou mais, cerca de $57 \%$ das pessoas com grau universitário jogam games, contra $51 \%$ com apenas o colegial, e contra $40 \%$ das pessoas com apenas o fundamental ou menos. Ainda de acordo com a pesquisa, estudantes podem ser classificados como jogadores ávidos, com uma taxa de $76 \%$ de usuários que jogam diariamente, comparados com $49 \%$ dos não-estudantes.

Em termos de classe social, essa diferença é também encontrada, ainda que de maneira mais moderada: $56 \%$ das pessoas com renda superior a US\$ 75.000 anuais jogam games, contra $52 \%$ das pessoas com menos de US\$ 30.000 anuais. Nisto, a pesquisa da BBC aponta resultados próximos: 52\% dos membros das classes A, B, C1 jogam, contra 48\% dos membros da classe C2, D, E.

De modo geral, o que essas e outras pesquisas indicam é que a população gamer em países que convivem de modo mais intenso com essa prática está, hoje, longe de coincidir com o perfil que ainda resiste no imaginário popular, do gamer como homem, jovem, de classe alta.

Jogar é um hábito que se espalhou pelos gêneros e por diferentes classes sociais. Tornou-se uma atividade corrente para uma parcela razoável da população mais idosa, uma prática comum para a geração dos trinta, um componente imprescindível de socialização quando se trata de adolescentes e um elemento praticamente natural quando falamos de crianças.

Também impressiona o grau de penetração nas diferentes classes sociais. A maior diferença não está tanto no poder aquisitivo, mas sim no grau de formação cultural e educacional (57\% contra 40\%). Jogar, neste sentido, torna-se uma prática cada vez mais universalizada, tal qual o uso que se faz de outros meios, como ver TV, ouvir música ou ir ao cinema. Jogar pode ser visto 
como um componente cada vez mais presente dentro do estilo de vida contemporâneo.

Ao projetar estes dados em escala mundial, percebe-se um fenômeno massivo, global, geracional e ainda em curso de consolidação, que estende sua influência não apenas àqueles que jogam, mas também, cada vez mais, àqueles que não jogam - mas que convivem com os gamers e a cultura gamer em casa, no trabalho, na escola e em outros momentos da vida social.

\section{4. - A INDÚSTRIA DE GAMES NO MUNDO}

A ascensão dos jogos eletrônicos ao longo das últimas três décadas também está atrelada ao surgimento e desenvolvimento do jogo como produto cultural. O tamanho da indústria de games já superou outras do setor, como a de música ou de revistas.

Matéria publicada na revista "The Economist", intitulada "All the world's a game", oferece uma visão objetiva a esse respeito.

Nas duas últimas décadas o negócio de video games evoluiu de uma indústria artesanal, que vendia para pequenos nichos de consumidores, para um dos ramos mais pujantes da indústria de entretenimento. De acordo com a consultoria PricewaterhouseCooopers (PwC), o mercado global de video games rendeu cerca de US\$ 56 bilhões em 2010. Isso é mais que o dobro do tamanho da indústria fonográfica, quase um quarto a mais do que o negócio de revistas e cerca de três quintos do tamanho da indústria de filmes, incluindo vendas de DVDs. PwC prediz que os video games serão a mídia de crescimento mais rápido ao longo dos próximos anos, com vendas subindo para US\$ 82 bilhões em 2015. (THE ECONOMIST, 2011).

De acordo com a consultoria norte-americana DFC Intelligence (DFC INTELLIGENCE, 2011), o mercado mundial de games movimentou US\$ 65 bilhões de dólares em 2011 (em 2010, foi estimada uma movimentação de 62,5 bilhões). Deste valor, US\$29 bilhões foram obtidos com a venda de consoles e 
títulos. Já outros US\$ 18 bilhões, com a venda de itens em jogos online, como Farmville e congêneres.

Já para o analista da indústria de games Colin Sebastian, o setor faturou USS 60 bilhões em 2011, motivado principalmente pelo crescimento nos jogos online e mobile (IBM, 2011). Para a PricewaterhouseCooopers (PRICEWATERHOUSECOOPERS, 2011), o setor de games alcançou a marca de US\$ 68,3 bilhões em vendas no ano de 2012 .

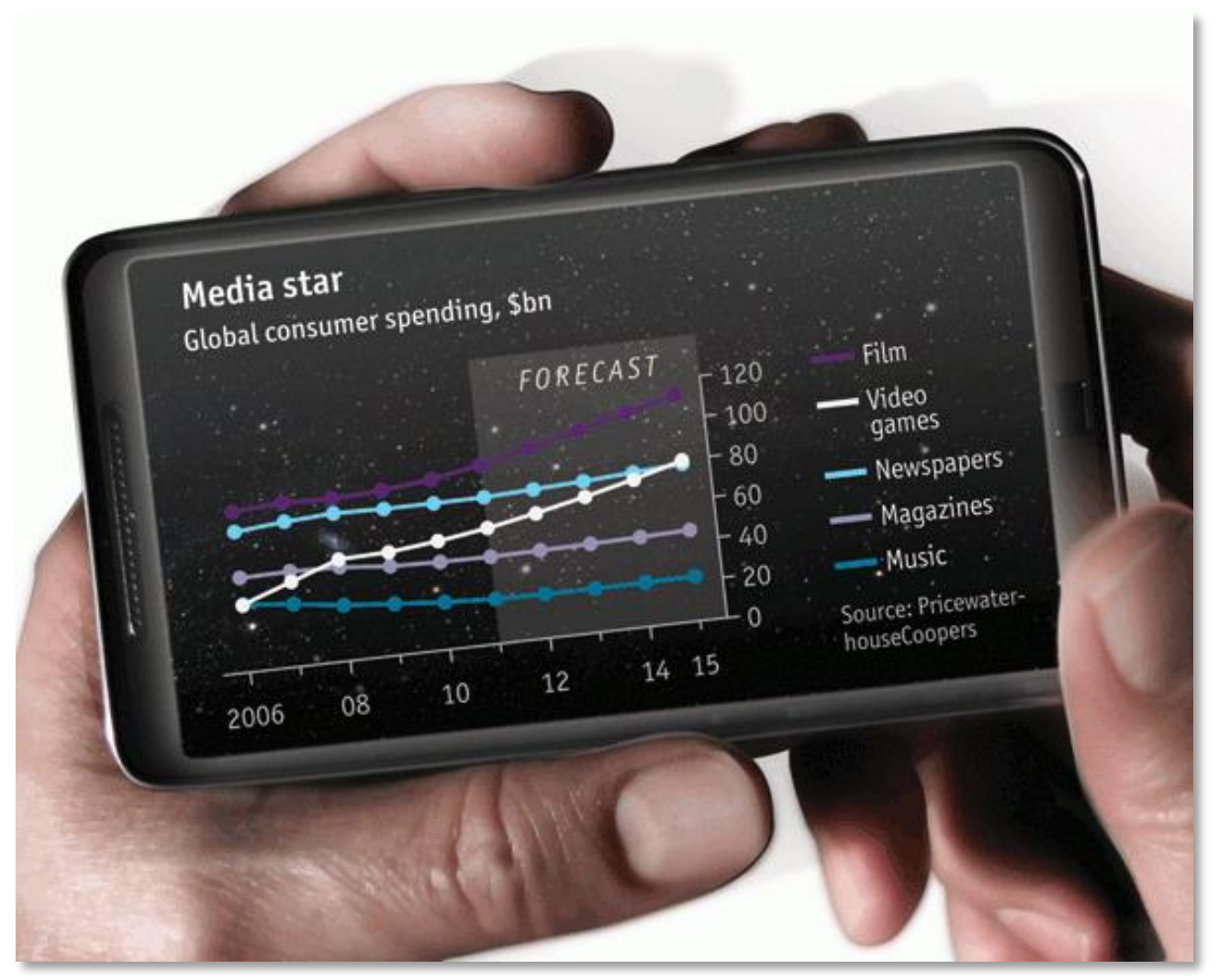

Figura 3: Faturamento anual por mídia até 2015 (Pricewaterhouse Coopers)

Em relação ao crescimento futuro, Sebastian prevê que a indústria alcance vendas de US\$ 80 bilhões em 2014. A DFC Intelligence aponta US $\$ 82$ bilhões em 2017, e PricewaterCoopers aposta que os US\$ 82 bilhões serão batidos pela indústria em 2015. 
Enfim, o que se depreende dessas estimativas é que a indústria de games, daqui a menos de uma década, será majoritária dentro da indústria cultural.

\section{5 - BRASIL: OS GAMERS E O MERCADO}

Segundo matéria publicada na Folha de São Paulo (FOLHA DE SÃO PAULO, 2012), de acordo com a pesquisa "Game Pop", conduzida pelo IBOPE nas treze maiores capitais do país, cerca de $23 \%$ dos brasileiros entrevistados jogam videogame ou algum tipo de jogo eletrônico, ao menos de vez em quando, perfazendo uma população de jogadores de 45,2 milhões de pessoas.

A divisão por gênero, de acordo com os dados da pesquisa IBOPE, seria relativamente equilibrada. Cerca de $53 \%$ dos jogadores são homens, contra $47 \%$ mulheres, acompanhando a tendência internacional, como já observado.

Em termos de faixa etária, a mais significativa é a de até 19 anos, respondendo por $40 \%$ dos usuários - algo natural, uma vez que o universo dos jogos eletrônicos no Brasil ainda está menos amadurecido do que países como EUA ou Grã-Bretanha.

A classe social também seria fator influente. De acordo com a pesquisa, $41 \%$ são membros da classe $B$, o que reforça a ideia de que, no Brasil, as práticas relativas ao jogo eletrônico ainda estejam razoavelmente atreladas à classe social à qual o indivíduo pertence.

Em relação ao volume de dinheiro movimentado, segundo matéria da Folha de São Paulo (FOLHA DE SÃO PAULO, 2012), a consultoria PricewaterhouseCoopers ( $P w C$ ) estima que o mercado nacional movimentou $\mathrm{R} \$$ 840 milhões em 2011, o que o colocaria como o quarto maior mercado do mundo. A previsão média de crescimento, segundo a consultoria, giraria em 
torno de 7,1\% ao ano, até 2016 - quando o mercado brasileiro atingiria o valor de R\$ 4 bilhões.

Pensado como negócio, os jogos no Brasil estão ainda dentro de um processo de maturação. Porém, os dados sugerem que esse quadro se altera paulatinamente, ano a ano, impulsionado pela disseminação massiva da internet e de aparelhos como celulares, tablets e computadores. 


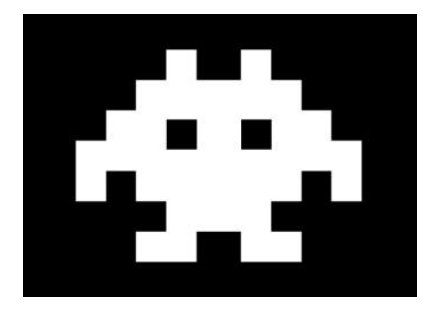

CAPÍTULO II:

AS MÚLTIPLAS FACES DO JOGO

\section{1. - AS MÚLTIPLAS FACES DO JOGO}

O campo de estudos sobre os jogos é conhecido por duas características: a primeira é que é um campo vasto, escrutinado por especialistas de áreas tão distintas como a Etologia, Psicologia, Antropologia, Sociologia, Filosofia e Comunicação.

E a segunda é que, a despeito das inúmeras tentativas de defini-lo, ele permanece ainda um campo em boa parte não desvendado, cercado por ambiguidades, elusivo quanto às classificações e generalizações com que a Ciência tenta elucidar seus objetos de estudo. 
À primeira vista, parece relativamente fácil identificar quando uma pessoa está envolvida num jogo. Por exemplo, tome-se duas crianças brincando num jardim, empreendendo uma disputa para ver se uma consegue pegar a outra. Quer o observador seja um participante da cultura global contemporânea, ou quer seja membro de outra tradição cultural, é quase instintivo para um ser humano identificar o comportamento delas como um jogo.

Por outro lado, embora identificar um jogo pareça muitas vezes uma atividade banal, facilmente reconhecível, alcançar uma definição precisa a respeito das fronteiras daquilo que é jogo (e do que não é) é tarefa que se demonstra praticamente impossível.

A razão disso, de maneira muito resumida, está no fato de que, sob a égide da palavra "jogo", abrigam-se um grande número de percepções, fenômenos, agentes e motivações, que impossibilitam uma totalidade explicativa mesmo para os mais bem elaborados esquemas teóricos.

Nas palavras do pesquisador-chefe do Laboratório de Pesquisa sobre o Jogo e o Jogar da Universidade Paris-Nord, Jacques Henriot (HENRIOT, 1989), citado por Brougère (BROUGÈRE, 1998, p. 17), "O jogo é uma coisa de que todos falam, que todos consideram como evidente e que ninguém consegue definir".

De antemão, o vocábulo "jogo", por si só, já traz consigo uma formidável polissemia, como será visto adiante, indicativa ela mesma da amplitude e da variabilidade com que esse tipo de fenômeno se manifesta dentro de inúmeros contextos. E que se adensa ainda mais, caso "jogo" seja utilizado no sentido mais amplo - que é o sentido original dado ao verbo "play" na língua inglesa e "spielen" na língua alemã - que considera como jogo atividades estruturadas em torno de regras informais, como as brincadeiras infantis, ou ainda considerando como jogo um tipo particular de fruição que é a participação vicária (assistir a uma peça de teatro, assistir a uma partida de futebol, etc..). 
Um bom exemplo de como opera essa polissemia é imaginar uma pessoa dialogando com outra. "Mostre um jogo às crianças". E a pessoa imediatamente ensina-as a jogar dados a dinheiro. "Não tive em mente um jogo como esse" dirá o primeiro (WITTGENSTEIN, 1999, p. 54).

$\mathrm{Na}$ tentativa de organizar melhor os níveis de entendimento atrelados ao termo jogo, Gilles Brougère, por exemplo, em seu livro "Jogo e Educação", distingue três contextos de uso diferentes para essa palavra. Em sua visão, jogo pode ser entendido primeiramente como "uma atividade, uma situação que se caracteriza pelo fato de que seres jogam, têm uma atividade que diz respeito ao jogo, qualquer que seja sua definição" (BROUGÈRE, 1998, p. 14).

Para ele, isso abrange desde atividades reconhecidas diretamente como jogo (uma partida de futebol) até ações que sejam nomeadas como jogo dentro de um plano metafórico (jogo político, jogo do amor, jogo da vida, etc.).

Mas, para Brougère, "jogo" também pode ser entendido como "uma estrutura, um sistema de regras (game, em inglês), que existe e subsiste de modo abstrato independentemente dos jogadores, fora de sua realização concreta em um jogo entendido no primeiro sentido" (BROUGÈRE, 1998, p. 14). Claro, nesta acepção, o jogo também transborda para o mundo real, na medida em que pode ser traduzido como um software, ou ainda como um espetáculo (um jogo de tênis televisionado, uma partida de futebol).

Finalmente, para Brougère, o jogo também é um objeto, numa associação que o aproxima de um brinquedo, embora, para ele, exista uma diferença fundamental, que é o uso dos objetos de jogo dentro de um sistema de regras que os dotem de sentido. Um tabuleiro de xadrez, nesta acepção, é um material lúdico que ganha expressão na medida em que é a representação concreta de um sistema de regras que o sustenta.

Já Wittgenstein, em sua obra "Investigações Filosóficas", segue outro caminho. Ele tenta dar conta dessa grande diversidade que se abriga sob o signo do jogo assumindo a ambiguidade que se embute nesse fenômeno e 
nessa palavra. Em seu aforismo 66, ele demonstra seu entendimento da questão:

Considere, por exemplo, os processos que chamamos de "jogos". Refiro-me a jogos de tabuleiro, de cartas, de bola, torneios esportivos, etc. O que é comum a todos eles? [...] Considere, por exemplo, os jogos de tabuleiro, com seus múltiplos parentescos.

Agora passe para os jogos de cartas: aqui você encontra muitas correspondências com aqueles da primeira classe, mas muitos traços comuns desaparecem e outros surgem. Se passarmos agora aos jogos de bola, muita coisa comum se conserva, mas muitas se perdem. - São todos recreativos?

Compare o xadrez com o jogo da amarelinha. Ou há em todos um ganhar e um perder, ou uma concorrência entre os jogadores? Pense nas paciências. Nos jogos de bola há um ganhar e um perder; mas se uma criança atira a bola na parede e a apanha outra vez, esse traço desapareceu. Veja que papéis desempenham a habilidade e a sorte. E como é diferente a habilidade no xadrez e no tênis.

Pense agora nos brinquedos de roda: o elemento divertimento está presente, mas quantos dos outros traços característicos desapareceram! E assim podemos percorrer muitos, mas muitos outros grupos de jogos e ver semelhanças surgirem e desaparecerem. E tal é o resultado desta consideração: vemos uma rede complicada de semelhanças, que se envolvem e se cruzam mutuamente. Semelhanças de conjunto e pormenor." (WITTGENSTEIN, 1999, p. 52)

Wittgenstein nomeia essa teia de semelhanças como "semelhanças de família", do mesmo modo que, dentro de uma grande família, encontramos tanto uma vaga semelhança entre os indivíduos que dela fazem parte, quanto algumas diferenças, quer seja a cor dos olhos, o temperamento, a estatura ou os traços fisionômicos. Ou seja, Wittgenstein entende os jogos como uma "família", impossível de ser definida nitidamente, mas semelhante o suficiente para que seus membros possam celebrar algo em comum. 
Porém, a polissemia dos jogos também se traduz através de outro prisma que não o da linguagem: pelas diferentes atividades através das quais o jogo se expressa dentro da experiência humana. Sutton-Smith (SUTTON-SMITH, 2001, p. 5) lista algumas nas quais o jogo pode surgir.

a) Jogos Mentais ou Subjetivos: sonhos, sonhar acordado, fantasia, imaginação, ruminações, divagações, Dungeons \& Dragons (RPG), metáforas de jogo, jogar com metáforas.

b) Jogos Solitários: hobbies, coleções, modelismo (trens, aviões, barcos), escrever para "amigos postais", construir maquetes, ouvir música, construções, projetos de arte, jardinagem, arranjos florais, utilização de computadores, assistir vídeos, leitura e escrita, novelas, brinquedos, viagem, simulações de batalhas, música, bichos de estimação, trabalhos em madeira, ioga, antiguidades, voar, corrida de carro, colecionar e reconstruir carros, velejar, mergulhar, astrologia, andar de bicicleta, trabalhos manuais, fotografia, fazer compras, viagem de mochila, pescar, bordar, observar pássaros, palavras-cruzadas, cozinhar.

c) Comportamentos de Jogo: pregar peças, brincar por aí, jogar contra o tempo, animar alguém através de brincadeiras, fazer troça de outros, fazer trocadilhos com as palavras, "fuçar" em equipamentos, colocar alguém na brincadeira, manter as coisas em jogo, jogar limpo, jogar contra as regras.

d) Jogos Sociais Informais: piadas, festas, cruzeiros, viagem, lazer, dança, skate, perder peso, jantares, jogos de conquista, jantares coletivos, passear no shopping, receber convidados, cuidar de crianças, "baladas", puxar e agarrar, parques de diversão, anacronismo criativo, parques de diversão, intimidades, jogos de fala (histórias, fofocas, nonsense), bares de solteiros, bares, mágica, radio-amador, restaurantes, internet.

e) Jogos de Audiência Vicária: televisão, filmes, quadrinhos, concertos, terras da fantasia, espectador de jogos, teatro, shows de música, desfiles (Carnaval, procissões, datas cívicas), concursos de beleza, corridas de automóveis, parques nacionais, festivais de folclore, museus, realidade virtual.

f) Jogos de Performance: tocar piano, tocar música, ser um ator, jogar o jogo "pela graça do jogo", "curtir" um determinado lugar (Nova York), 
pescaria, cavalgada, imitar e fazer vozes diferentes, fazer mímica, brincar por brincar.

g) Celebrações e Festivais: aniversários, Natal, Páscoa, Dia das Mães, troca de presentes, banquetes, churrascos, casamentos, festivais, iniciações.

h) Disputas (jogos e esportes): atletismo, jogos de azar, cassinos, cavalos, loterias, bolões, futebol, luta de pipas, golfe, gincanas, beber entre amigos, Olimpíadas, touradas, briga de galo, críquete, pôquer, "truques sujos", estratégia, habilidades físicas, sorte, disputas entre animais, arqueria, queda de braço, jogo de tabuleiro, jogos de cartas, artes marciais, ginástica.

i) Jogos de Risco: exploração em cavernas, asa delta, caiaque, rafting, esquiar na neve, bunguee jumping, windsurf, escalada, mountain bike, ultramaratona, pular de paraquedas.

E da mesma maneira com que o jogar se espraia pelas mais diferentes atividades humanas, também é possível perceber sua presença através do seu vasto número de agentes (de crianças a atletas); ou ainda através dos equipamentos utilizados para o jogar, que vão desde os mais formais (bolas, tacos, dados, cartas, peças, softwares) até os mais informais, já que praticamente qualquer coisa pode se tornar um objeto de jogo.

Outra maneira de se dar conta da amplitude do jogo (e de suas definições) é através do fato de que ele largamente ultrapassa a fronteira da humanidade, podendo ser encontrado não só em praticamente todos os grupos de mamíferos, mas também em aves. O eminente etologista Robert Fagen, em seu clássico trabalho "Animal Play" (1981), oferece exemplos de comportamento de jogo em mais de quinhentas espécies diferentes de mamíferos e aves, e aponta ainda dois estudos sobre comportamento de jogo até mesmo em répteis, como os crocodilos, que gozam de certo parentesco com as aves (coração com quatro câmaras, cuidados pós-natais). De certa maneira, o jogo parece atrelar-se ao próprio desenvolvimento da inteligência.

Ademais, a confirmação de que outras espécies também jogam obriga os estudiosos do jogo a enquadrar esse fenômeno, dentro da esfera humana, não 
apenas eminentemente como uma manifestação cultural, mas sim como um algo anterior à cultura, como uma força primeva.

Talvez por conta disso, vários teóricos tenham insistido em buscar a raiz do jogar dentro do comportamento animal, já que nesse campo estariam menos suscetíveis às complexas variações culturais, psicológicas e sociais encontradas na espécie humana.

Ao realizar um balanço dos estudos sobre o jogo animal, autores como Salen e Zimmerman (SALEN e ZIMMERMMAN, 2004, p. 309) indexam algumas das supostas motivações ou funções que, desde o século XVIII, eram tipicamente associadas com o jogar em diversos campos de estudo, tendo como pano de fundo uma explicação biológica.

Via de regra, essas teorias procuravam divisar uma função ou vantagem evolutiva associada ao jogo. Dentre outras possibilidades, o fenômeno do jogo era comumente associado a:

a) Gasto de um "surplus" de energia.

b) Expressão de exuberância geral, "joie-de-vivre".

c) Expressão de impulsos relacionados ao sexo, à agressão ou ainda ansiedade.

d)Treino, prática juvenil de habilidades relacionadas à vida adulta.

e) Contexto para exploração e experimentação.

f) Um meio de socialização.

g) Ferramenta para auto-expressão e diversão.

Entretanto, esse tipo de explicação, que procurava oferecer uma função de ordem biológica para justificar a existência do jogo, não se provou suficiente para dar conta da totalidade desse fenômeno. Como diria Huizinga,

O mais simples raciocínio nos indica que a natureza poderia igualmente ter oferecido às suas criaturas todas essas úteis funções de descarga de energia excessiva, de distensão após um esforço, de preparação para as exigências 
da vida, de compensação de desejos insatisfeitos, etc., sob a forma de exercícios e reações puramente mecânicos. Mas não, ela nos deu a tensão, a alegria e o divertimento do jogo. (HUIZINGA, 2001, p. 5)

Um exemplo prático que demonstra os limites desse tipo de interpretação é o fornecido pela etologista Lynda Sharpe, em depoimento à Scientific American. Durante catorze anos ela estudou em campo o comportamento de pequenos mamíferos habitantes do deserto de Kalahari, chamados de suricatas. Seu objetivo, ao acompanhar o crescimento de quarenta e cinco suricatas, era comprovar se comportamentos de jogo efetivamente se traduziam em vantagens para seus participantes.

O resultado de suas observações foi que indivíduos que brincavam mais de "caçador" não se transformavam em melhores caçadores do que aqueles que jogavam menos. Do mesmo modo, suricatas que brincavam juntos e eram mais sociáveis não desenvolveram laços de amizade superiores aos que não brincavam tanto. E nem aqueles que brincavam mais de "luta" desenvolveramse preponderantemente como machos dominantes. Vários outros estudos com coiotes, gatos e outros mamíferos chegaram à mesma conclusão (SHARPE, 2011).

É o que exemplifica Sutton-Smith, rebatendo a idéia de que o jogo, por exemplo, é uma preparação para a vida: "Em termos humanos, quantos de nós vamos assistir a uma peça, ou a um filme, ou assistir desenhos primariamente para ganhar informação a respeito de habilidades úteis para a vida real?" (SUTTON-SMITH, 2001, p. 27).

É essa ambiguidade que leva Fagen (FAGEN, 1981), citado por SuttonSmith (SUTTON-SMITH, 2001, p. 2) a afirmar que

A mais irritante característica do jogo não é sua incoerência perceptual, como tal, mas sim, que o jogo nos provoca com sua inacessibilidade. Nós sentimos que algo está por trás de tudo, mas nós não sabemos, ou esquecemos como enxergar isso. 
Essa sensação de areia escapando das mãos se deve, em boa parte, à maneira sutil como esse fenômeno se infiltra na vida cotidiana. Pois como definir algo que se insinua, sem aviso, nas mais variadas necessidades e motivações?

Ainda assim, especialmente nos últimos dois séculos, propagaram-se as mais diferentes definições sobre jogo, a partir de suas múltiplas expressões e cruzamentos dentro da experiência humana.

Burghardt, em seu livro "The Genesis of Animal Play: Testing the Limits" lista alguma delas (BURGHARDT, 2006, p. 7), produzidas por pesquisadores de diversos campos de estudo, o que apenas reforça a sensação de perplexidade diante de tão diferentes maneiras de se perceber o jogo:

a) Jogo é liberdade.

b) Jogo é um respiro essencial das seriedades da vida.

c) Jogo é um comportamento sério nos quais as artes da guerra são aprendidas.

d) Jogar é simplesmente vagabundear: o começo de um caminho que leva à delinquência, apostas e até mesmo crime.

e) Jogo é encorajado pelos poderosos da sociedade para distrair as massas de suas opressões, ou mais benignamente, para amenizar a falta de controle sobre as decisões que os afetam.

f) Jogo carrega em si toda a criatividade e inovação, incluindo arte e ciência produzida pelos adultos.

g) Jogo é o manancial dos rituais e mitos pelos quais nós estruturamos nossas vidas. Toda vida é um jogo ou um palco no qual nós atuamos durante o nosso tempo dado.

h) Jogo é um produto burguês da industrialização e ganhou tal denominação apenas após o trabalho tornar-se apartado da vida cotidiana.

i) Jogo é a feliz e entusiástica participação na vida.

j) Jogo é um esporte cruel, tenso e competitivo. 
A partir desse quadro de extensa diferença, Sutton-Smith sugere a seguinte saída teórica. Para ele, em torno das diferentes vivências e aproximações em relação ao jogo, foram sendo forjadas diferentes retóricas, que buscam, implícita ou explicitamente, convencer e persuadir os outros a respeito da veracidade de suas crenças. E cada uma dessas retóricas acaba por descrever o jogo a partir de um contexto mais amplo de entendimento.

Sutton-Smith enumera sete grandes tradições, cada qual com sua própria retórica e associadas a diferentes tradições históricas, significados, formas, disciplinas e teóricos. Embora todas sejam válidas, em suas diferenças elas demonstram o que talvez seja uma das poucas concordâncias em relação ao jogo: sua grande variabilidade contextual. Em resumo, essas sete retóricas buscam aproximações com os jogos da seguinte maneira (SUTTON-SMITH, 2001, p. 9):

a) Jogo como Progresso - por esta retórica, o jogo é visto como uma adaptação, como um mecanismo de progresso, como uma forma de desenvolvimento do cérebro, como uma maneira de indivíduos jovens adquirirem habilidades, socializarem, amadurecerem as emoções. Surgida a partir do Iluminismo, usualmente é aplicada no estudo de animais e em estudos sobre o jogo infantil. Para Sutton-Smith, é uma visão que agrada bastante aos pais e ao público ocidental, embora sua eficácia tenha sido "mais assumida do que demonstrada" (SUTTON-SMITH, 2001, p. 9). Nela, o jogo é visto, muitas vezes, muito mais como uma forma de desenvolvimento do que de divertimento.

b) Jogo como Destino - é provavelmente a retórica mais antiga e remonta ao próprio conceito do homem como um joguete dos deuses. Aqui, o jogo é associado à pura aleatoriedade, ao caos, à sorte, ao destino e às tentativas de manipulação a partir de oráculos e práticas animistas. Embora esteja em desprestígio junto à elite intelectual, ainda se manifesta com vigor na cultura popular. Ela contrasta com teorias mais modernas que definem o jogo, por exemplo, como uma questão de livre escolha. 
c) Jogo como Poder - esta retórica diz respeito ao uso do jogo como mecanismo de hegemonia. Aqui, jogo é estratégia, habilidade, com um fim claro de vitória e dominação. O jogo é pensado como representação de um conflito e uma maneira de fortalecer o status quo. Huizinga, de certo modo, ao apontar o jogo civilizatório como uma competição entre nações, participa dessa visão. É uma retórica tão antiga quanto a guerra e o patriarcado. Encontra eco na contemporaneidade principalmente nos esportes, embora seja desprezada por estudiosos que enxergam o jogo como lazer e divertimento.

d) Jogo como Identidade - aqui, o jogo é visto como meio de interação simbólica, criação de laços, vida comunal, (festividades, performances teatrais e até mesmo como rituais religiosos, como enterros e casamentos). Neste caso, o jogo é visto como um meio de confirmação e manutenção de um vínculo social. É uma abordagem popular entre antropólogos e folcloristas.

e) Jogo como Imaginário - usualmente é aplicada a toda sorte de improviso na literatura e em outros lugares. Ela idealiza a imaginação, a flexibilidade e a criatividade que permeiam o jogar. Associada ao movimento romântico, acadêmicos da área literária e das artes ainda hoje enxergam o jogo a partir dessa perspectiva, tornando essa retórica uma das mais populares nos dias de hoje.

f) Jogo como Self - é uma retórica muito presente quando se descrevem atividades solitárias como hobbies ou esportes radicais que produzem atividades de pico, como bungee jumping. Suas bases científicas examinam a diversão, o relaxamento, o escape proporcionado pelo jogo. Aqui existe uma conexão com o consumismo e o individualismo presentes na vida moderna.

g) Jogo como Frivolidade - esta retórica abriga tanto as descrições de jogos que se manifestam a partir da inversão da ordem social (Carnaval) reino dos bufões, dos mascarados, dos bobos da corte - quanto, também, a do jogo como atividade negativa, oposta ao trabalho e à virtude. 
Naturalmente, essas retóricas não operam com o mesmo peso dentro da dinâmica contemporânea. Discursos pertencentes a certas retóricas (como a antiquíssima retórica que pensa o "jogo como Destino") encontram dificuldade em impor-se numa sociedade que, ao menos nos últimos duzentos anos, se imagina calcada no mérito, no progresso e na ciência.

Viver, dados os avanços da medicina e os níveis cada vez maiores de controle da violência, tornou-se uma tarefa muito menos arriscada do que anteriormente.

Ademais, a sorte, o destino, o acaso, que se agigantam em tempos de guerra, de peste e de tragédias naturais, tornam-se elementos menos evocados em tempos de calmaria.

Ainda assim, é uma retórica que não perdeu de todo o seu poder. 0 grande apelo das loterias, a despeito da enormidade das chances em contrário, é uma demonstração de como a Fortuna ainda arrebata magicamente corações e mentes treinados para o racionalismo. E os jogos de azar, embora não gozem do mesmo prestígio dos games, ainda respondem por um faturamento dez vezes maior.

Do mesmo modo, outras retóricas antigas - como as que enxergam o "Jogo como Poder" ou "Jogo como Identidade" - ainda que acossadas pela ampliação dos Direitos Humanos, pela alta regulação do comportamento social, enfim, pela noção de civilização, com todo o mal-estar que isso provoca, são capazes de volta e meia se impor no cenário social. Elas se expressam nos cânticos enlouquecidos das torcidas nos estádios, nas exaltações ao Carnaval e nos games de tiro com seus enredos supremacistas.

Por outro lado, retóricas que surgiram na esteira do Iluminismo, como a do "Jogo como Progresso", ou que sofreram influência do Romantismo, como o "Jogo como Imaginário", ou ainda de fontes mais modernas, como o "Jogo como Self", gozam de mais trânsito dentro da conjuntura contemporânea. 
É mais fácil para os ouvidos modernos conceber o jogo como "uma ferramenta para o aprendizado", ou "um treino para a vida". É mais palatável imaginar o jogo como uma "disposição pessoal", "uma intencionalidade" intrinsecamente motivada, divertida e livre, do que como um fenômeno extrínseco, governado pela vida comunal, um dever nem sempre prazeroso, como o são diversos rituais de tribos e comunidades rurais.

Finalmente, é impossível não mencionar a influência até poucas décadas inconteste, e ainda hoje bastante influente, que a retórica do "Jogo como Frivolidade" exerce dentro do corpo social, fruto de séculos do martelar de valores puritanos em relação ao jogar, bem como da pressão exercida pela ideologia capitalista nos últimos quatrocentos anos, que viu durante muito tempo no jogo um inimigo a ser combatido (tempo é dinheiro, e o jogo é, sob esse ponto de vista, uma perda de tempo).

Ainda hoje, ecos desses discursos assombram aqueles que jogam. Jogadores são "viciados em games". Jogar, muitas vezes, é associado a vagabundear. Jogos são vistos como "perda de tempo", ou uma atividade restrita ao universo infantil. Ou ainda, só são bem vistos se forem direcionados para alguma atividade "produtiva", como treinamento corporativo ou como ferramenta de educação.

Talvez por conta da força desta última retórica, como diria Lhôte, autor da maior enciclopédia sobre jogos em língua francesa: "O jogo permanece um universo obscuro, frequentemente suspeito, raramente observado com atenção e ainda mais raramente visto com simpatia" (LHÔTE, 1994, p. 7)

Mas, afinal, o que essas diferentes concepções de jogo demonstram? Essa impressionante variedade e também sua aparente disparidade parecem lançar sobre o jogo muito mais um véu de ocultamento do que efetivamente aclarar alguma coisa, pois algo que se desdobra em muitas possibilidades, em verdade, não se compromete inteiramente com nenhuma delas. 
É essa característica que faz com que Spariosu qualifique o jogo com a palavra grega "anfibolo", que significa um objeto que corre simultaneamente para direções opostas, em flagrante ambiguidade (SPARIOSU, 1989).

Para ele, a despeito do crescente interesse no conceito de jogo e nas centenas de definições a respeito de sua natureza e função, ainda assim esse é um fenômeno que permanece nos dias de hoje tão elusivo quanto há dois mil anos atrás, podendo ser enquadrado naquilo que os germânicos classificam como "das stumme Wissen" (conhecimento tácito), ou seja, um conhecimento muito mais fácil de ser intuído do que racionalizado.

Ao fim, no entremear de todas essas diferentes retóricas e tradições, que competem pela primazia explicativa a respeito dos jogos, o que resta, na visão de Sutton-Smith, são apenas as ideologias, preconceitos e disciplinas das pessoas que tentam desvendar esse enigma.

Spariosu coaduna com a visão de Sutton-Smith. Para ele, por exemplo, essas diferentes visões a respeito do jogo traduzem uma:

[...] Incomensurável, descontínua série de interpretações engajadas numa disputa pela supremacia. A história daquilo que nós chamamos de 'jogo' no mundo Ocidental é, portanto, uma história de conflito, de competição entre conceitos de jogo que ora tornam-se dominantes, ora cedem terreno, para então reemergirem, de acordo com as necessidades dos vários grupos e indivíduos que pelejam por autoridade cultural num dado período histórico (SPARIOSU, 1989, p. xi).

Em outros termos, uma definição de jogo, dadas as diferentes razões explicativas pelas quais pode ser construída, mostra-se sempre como uma meta instável, fugidia, ambígua. Ela será sempre a expressão da hegemonia de alguma retórica.

O jogo, ao cabo de tudo, permanece um mistério, ao mesmo tempo em que opera como um espelho: ele apenas reflete os próprios termos nos quais foi inquirido. $E$, ao tentar desconstruir essa ambiguidade e alcançar uma definição precisa, "nós caímos em tolices" (SUTTON-SMITH, 2001, p. 1). 


\subsection{EM BUSCA DE UMA DEFINIÇÃO DE JOGO}

Propõe-se como norte desta análise uma frase muito simples e direta, encontrada no "Homo Ludens" de Huizinga. Antes de mencioná-la, porém, vale comentar que alguns autores modernos possuem uma postura dual em relação a esse pioneiro.

Por um lado, o aplaudem, já que o atrevimento desse autor foi o de provocativamente clamar pelo jogo como uma das mais fundamentais funções humanas, permeando todas as culturas desde o início, desvencilhando-o de puritanismos e visões utilitaristas reinantes na época.

Por outro lado, Huizinga é acusado, às vezes, de realizar análises carentes de um aprofundamento metodológico mais claro (ECO, 1989, p. 274), ou ainda de se abrigar numa mentalidade romântica, na qual o jogo aparece idealizado e sacralizado (SUTTON-SMITH, 2001, p. 203).

De fato, Huizinga é ardoroso, romântico e mesmo aristocrático em sua argumentação. Entretanto, seu livro permanece como fonte primordial para qualquer estudo na área de jogos não apenas por seu valor histórico, mas principalmente porque - ao menos no entendimento contemporâneo que se tem do jogo - Huizinga foi extremamente lúcido ao propor que o jogo fosse estudado em seus próprios termos, e não como algo menor, coadjuvante de outras ciências.

Isso fica claro logo no início de seu livro, quando o autor, procurando desatrelar o estudo dos jogos das teorias que buscavam justificar esse fenômeno a partir de causas puramente biológicas, é incisivo ao afirmar qual deveria ser o foco das pesquisas. Para ele, "o jogo deveria ser considerado em si mesmo e naquilo que ele significa para os jogadores" (HUIZINGA, 2001, p. 5).

Por que o bebê grita de prazer? Por que motivo o jogador se deixa absorver inteiramente por sua paixão? Por que uma multidão imensa pode ser levada ao delírio por um jogo de futebol? [...] É nessa intensidade, nessa 
fascinação, nessa capacidade de excitar que reside a própria essência e a característica primordial do jogo (HUIZINGA, 2001, p. 5).

Como "jogo em si mesmo", numa leitura literal, já se assumiu a impossibilidade de uma objetividade. Por outro lado, a frase de Huizinga pode ser encarada como uma disposição para tentar explorar o jogo em suas particularidades, em seus mecanismos internos (mesmo operando inevitavelmente dentro de certas retóricas).

Opta-se, assim, por definir o jogo (dentre as muitas e legítimas definições possíveis) a partir de um prisma comunicacional, pela constatação de que, em sua expressão contemporânea a partir dos games eletrônicos, o jogar reflete, em si - suas temáticas, suas mecânicas, sua estética, suas possibilidades de interação -, uma cadeia de valores dentre os quais, como valor-base, se inclui a vocação comunicacional desta sociedade.

Por isso, a discussão se encaminhará primeiro para demonstrar que o jogo é uma linguagem. Segundo, que pode ser pensado como um meio de comunicação de massa. E terceiro, que seu modus operandi contém certas particularidades, fundamentais para posteriormente se entender a conexão entre o jogo e a dinâmica contemporânea.

Quanto à segunda afirmação, "o que o jogo significa para os jogadores", não é intenção esquadrinhar todas as possíveis motivações internas que fazem com que as pessoas joguem. As razões íntimas para se jogar são as mais variadas, assim como são variados os motivos pelos quais as pessoas, por exemplo, se dispõem a ir ao cinema, ou ler um livro.

Joga-se por prazer, joga-se por alegria, joga-se por tédio, joga-se para espantar a tristeza, joga-se para alívio da solidão, joga-se para se enturmar, joga-se para se exibir, joga-se por escapismo, joga-se por curiosidade. Jogar pode ser veículo para muitas coisas, inclusive para o sentimento de jogar por jogar. E isso, em si, é algo a ser considerado como um indício da qualidade do jogo como uma forma especial de comunicação. Afinal, visto como uma 
linguagem, o jogo exerce naturalmente essa função de expressão dos mais diferentes sentimentos e atitudes.

Ao examinar porque o "jogo é significativo para os jogadores", o que se pretende aqui é evidenciar a conexão entre o jogo e determinadas sensações que são produzidas pelo mecanismo de funcionamento do jogar - jogo como fonte de diversão, jogo como fonte para o exercício da fantasia e jogo como fonte de onipotência.

\subsection{JOGO COMO LINGUAGEM}

Em 1952, na tentativa de desvendar a origem da fascinação pelo jogo, Bateson propõe uma perspectiva inovadora a partir da biologia. Para ele, o jogo se revelaria na intencionalidade dos que dele participam.

Afinal, quer esteja formalizado através de regras, quer seja apenas uma brincadeira, o fato é que jogar envolve, acima de tudo, uma disposição mental, uma intenção, uma vontade e consciência peculiares, que tornam aquele ato particular diferente de outros atos, mesmo que ele seja exteriormente similar.

Na visão de Bateson, ao se especular sobre a origem da comunicação em termos biológicos, uma fronteira fundamental se estabelece no momento em que um organismo gradualmente deixa de responder "automaticamente" aos signos emitidos por outro organismo e começa a tomar consciência de que esses signos emitidos pelo outro são, em verdade, sinais.

Sinais que podem ser acreditados, iniciando-se um rudimento de linguagem. Mas sinais que, dentro de uma sofisticação do quadro evolutivo, também podem ser desacreditados, falsificados, negados, ampliados, corrigidos e daí por diante (BATESON, 2000, p. 178), naquilo que seria a base de uma meta-comunicação, essa sim capaz de gerar complexidades como empatia, identificação, projeção (BATESON, 2000, p. 179). 
Nesse momento hipotético estaria a origem do jogo, pois este fenômeno só poderia ocorrer se os organismos participantes fossem capazes de sustentar algum grau de meta-comunicação, no qual aquilo que se denota não é aquilo que se intenciona.

Em seu exemplo clássico, Bateson menciona dois cães, brincando de se morderem. A mordida "de brincadeira", de fato, significa uma mordida dentro do contexto do jogo, mas paradoxalmente não conota aquilo que uma mordida em situação de real combate significaria (BATESON, 2000, p. 180). Para ele, estaria aí resumida a situação intrinsecamente paradoxal do jogo.

É o que leva o próprio Bateson a pensar no jogo como uma inescrutável forma de meta-comunicação que sorrateiramente se espraia por praticamente todos os ramos da experiência humana.

Posteriormente, operando a partir desse conceito-chave de Bateson, Sutton-Smith formula, em seu livro "Toys as Culture", uma definição de jogo que evidencia com mais clareza seus contornos como linguagem.

Para Sutton-Smith, jogar seria, em primeiro lugar, (a) uma forma primitiva de comunicação. Primitiva não no sentido de pouco apurada, mas sim porque ela ocorre não apenas entre humanos, mas também entre animais.

Sendo uma linguagem, é algo que necessita de tempo para ser aprendido e, mais importante ainda, é algo que precisa ser aprendido com os outros membros do grupo.

Seus sinais, no plano físico, são específicos. Cachorros abanam o rabo, primatas sorriem e batem na garganta, humanos exageram e distorcem suas ações usuais. Fazem barulhos engraçados, mímicas absurdas, riem, galopam, pulam.

Em segundo lugar, jogar seria também (b) uma forma primitiva de expressão. Mais do que uma forma de comunicação, jogar seria uma maneira de se expressar, regida por regras específicas, a mais importante das quais é a 
representação altamente esquematizada do ser, lançando mão de pantomima, caricatura, sons, ações exageradas e representações esquemáticas.

O sentido disso não é apenas o de comunicar ao outro "isto é um jogo". Essas são características-chaves que fazem parte da própria estrutura do jogar. Crianças brincando de casinha conseguem, em poucos minutos, simular o que seria um dia inteiro numa casa real. Jogadores de futebol representam esquematicamente, em uma hora e meia, o conflito entre dois grupos, com seus guerreiros especializados e táticas de dominação.

O jogo, em sua expressão, esquematiza a vida. Ele alude à vida, mas não a imita num sentido estrito, como advogam muitos teóricos. Ele fagocita o sentido original, distorce, reaproveita as partes e constrói autonomamente outro sentido.

Ademais, em terceiro lugar, jogar também pode ser visto como (c) uma forma paradoxal de comunicação. Paradoxal na medida em que a atividade sugestionada não significa, de fato, a atividade real. Uma criança brincando de arrumar a casa não está, de fato, arrumando a casa, embora esteja "arrumando a casa". Os dois cães de Bateson, ao brincarem de mordida, não estão de fato se mordendo, embora em seu ato físico estejam se mordendo.

Esse relacionamento ambivalente entre jogo e vida, na visão de SuttonSmith, evidencia uma quarta qualidade do jogo, que é a sua (d) constante bipolaridade entre as fronteiras da vida cotidiana e o jogo, recorrentemente reequilibradas.

Essa guerra de fronteiras entre esses dois limites pode ser bem entendido pelas primeiras brincadeiras infantis, como a brincadeira de esconder. A criança se esconde atrás de um pano qualquer e depois coloca a cabeça para fora do pano, revelando-se novamente ("Achoooou!"), ou ainda qualquer brincadeira que mostre a sucessiva repetição entre estados alternados, como atacar e defender. 
Jogar é, dentro de um estado real, entregar-se a uma realidade paralela que, paradoxalmente, por sua vez, não possui condições de firmar-se definitivamente como tal. Como numa alucinação, o cérebro é obrigado a conviver com duas percepções distintas e realizar um rebalanceamento constante entre elas.

Por fim, como quinta característica, o jogo é considerado (e) uma forma primitiva de simbolização de motivações subjacentes. $O$ jogo é um veículo que, certamente precedendo a arte e a linguagem, é capaz de compartilhar estados emocionais com aqueles que partilham da mesma ação.

O resultado disso pode ser facilmente observado ao se analisar quantos estados de espírito, emoções e motivações ganham forma através do jogo. Jogar pode ser a forma de velhos amigos se confraternizarem, de Estados adversários demonstrarem a superioridade um sobre outro, de uma mãe e um filho passarem bons momentos juntos, de casais apaixonados demonstrarem interesse mútuo, de jovens disputarem a supremacia num grupo.

Ademais, essa capacidade de trânsito de motivações subjacentes frequentemente forma uma conexão que deixa à parte todos os que não estão jogando. Isso é facilmente comprovável ao ver que a excitação que percorre aqueles que estão jogando muitas vezes não é compartilhada por aqueles que estão alheios ao jogo. 0 jogo, de certa forma, possui a qualidade de formar um "grupo secreto" a partir dessas emoções subjacentes.

\section{4. - JOGO COMO MEIO DE COMUNICAÇÃO DE MASSA}

Pensar o jogo como uma meta-comunicação, ou como uma forma de comunicação primitiva é algo que já foi divisado, principalmente por autores dedicados ao jogo dentro no universo infantil. Vários teóricos já apontaram essa proximidade entre jogo e linguagem, como Piaget, ao descrever o jogo 
simbólico (PIAGET, 1988) como mecanismo-chave pelo qual a criança aprende, ou ainda Winnicott, quando propõe o jogar como um estado transicional, uma ponte, um veículo entre a realidade psíquica e a realidade externa (WINNICOTT, 1975).

Porém, na área de Comunicação, essa conexão entre jogos e linguagem só foi percebida de maneira direta por McLuhan, em 1964, ao publicar sua obra clássica "Os Meios de Comunicação como Extensões do Homem". Ele é claro ao apontar:

Como nossos idiomas vernáculos, todos os jogos são meios de comunicação interpessoal e não possuem existência nem significado a não ser como extensões de nossas vidas interiores imediatas. (MCLUHAN, 2011, p. 266)

McLuhan não tinha, àquela altura, condições de antever a prolífica relação que 0 jogo teria com as novas tecnologias computacionais, nem prever a importância que os jogos tomariam dentro da dinâmica cultural moderna. Por isso mesmo, sua antevisão de que os jogos podem ser considerados meios de comunicação de massa é ainda mais surpreendente:

Se se perguntar, finalmente: 'os jogos são meios de comunicação de massa?' - a resposta tem de ser: 'Sim'. Os jogos são situações arbitradas que permitem a participação simultânea de muita gente em determinada estrutura de sua própria vida corporativa ou social. (MCLUHAN, 2011, p. 275)

A se concordar com McLuhan, para além da fascinação que exercem enquanto entretenimento, os jogos eletrônicos também podem e devem ser considerados como meios de comunicação de massa, um conceito que será explorado na conclusão do trabalho.

Porém, mais que isso, McLuhan atenta para algo fundamental relativo ao jogo. A de que esse fenômeno possui, além de uma linguagem particular, uma dinâmica particular. 
A forma de qualquer jogo é de primordial importância. A teoria do jogo, como a teoria da informação, ignorou esse aspecto do jogo e do movimento informacional. Ambas as teorias têm tratado do conteúdo informativo dos sistemas, limitando-se a observar os fatores de "ruído" ou de "fraude" que distorcem os dados. É como abordar um quadro ou uma composição musical do ponto de vista do conteúdo. Em outras palavras, este é o caminho mais seguro para ignorar o cerne estrutural da experiência. Pois assim como é o padrão de um jogo que the confere relevância para a nossa vida interior - e não quem joga ou o resultado do jogo - assim também se dá com o movimento da informação (MCLUHAN, 2011, p. 272).

Em primeiro lugar, a crítica realizada às teorias Funcionalistas, implícita na fala de McLuhan, poderia também, em igual medida, ser destinada à escola de Frankfurt. Pois ambas as teorias fundadoras, embora diametralmente opostas entre si, expressavam uma visão comum sobre os "receptores" da comunicação: seres apassivados e manipuláveis, numa postura que, na melhor das hipóteses, subestimava o jogo de negociação de sentidos dentro do processo comunicacional, visão esta que só ganharia proeminência na área da Comunicação tardiamente, a partir da década de oitenta, com os estudos culturais ingleses e posteriormente com sua contraparte latino-americana.

De fato, a relação de predomínio do emissor sobre o receptor é a idéia que primeiro desponta, sugerindo uma relação básica de poder, em que a associação entre a passividade e receptor é evidente. Como se houvesse uma relação sempre direta, linear, unívoca e necessária de um pólo, o emissor, sobre outro, o receptor [...] e não eixos de um processo mais amplo e complexo, por isso mesmo, permeado por contradições (SOUSA, 1995, p. 14).

Porém, de todas as suas observações, a que mais impressiona é aquela na qual exerce seu mantra de que o "meio é a mensagem". McLuhan busca compreender os jogos a partir de seu padrão, de sua estrutura, de sua forma específica, daquilo que, em suma, o diferencia de outras linguagens. McLuhan iguala a experiência de jogo à da fruição de uma obra de arte. 
Para ele, tanto a "Arte, como os jogos, como os meios de comunicação têm o poder de impor seus próprios pressupostos, reordenando a comunidade humana por meio de novas relações e atitudes". Em sua visão, tanto a Arte quanto os jogos são ambos "tradutores de experiência" e sua existência não tem sentido ou função fora dos efeitos que produz sobre os observadores (MCLUHAN, 2011, p. 272).

\section{5. - O MODUS OPERANDI DO JOGO}

Nesse sentido, a visão de McLuhan se aproxima da de Hans-Georg Gadamer, filósofo alemão que quatro anos antes, em 1960, publicara "Verdade e Método". Neste livro, Gadamer não está diretamente interessado em desvendar o conceito de jogo. Ele o utiliza para demonstrar a falibilidade da "metafísica da subjetividade" na apreciação estética da obra de arte, este sim seu verdadeiro alvo.

Na trilha de Heidegger, Gadamer buscava, pensando no jogo como uma experiência para além da subjetividade do jogador, desmantelar a tese que vê o Sujeito como o ser que subjaz a tudo, criador e legitimador dos "objetos", medida de todas as coisas, herança do Cartesianismo.

Para ele, o jogo é um exemplo que demonstra os limites dessa subjetividade do indivíduo, já que "[...] o jogo não surge na consciência do jogador, e enquanto tal é mais do que um comportamento subjetivo" (GADAMER, 2008, p. 23).

Para Gadamer, tanto o jogo quanto a arte, quanto a festa, são experiências que só podem ser verdadeiramente compreendidas se encaradas de forma aberta, para além da consciência do indivíduo, no próprio ato de sua vivência. "A festa só existe na medida em que é celebrada" (GADAMER, 2008, p. 181). 
Do mesmo modo, a arte, mecanismo simbólico por excelência, só pode ser compreendida como verdade na medida em que o espectador se proponha a vivenciá-la, saia de si, de sua subjetividade, indague-se sobre o que ela tem a Ihe dizer e a confronte com suas expectativas.

A experiência da obra de arte sempre ultrapassa, de modo fundamental, todo horizonte subjetivo de interpretação, tanto o horizonte do artista quanto de quem recebe a obra. A mens auctoris não é nenhum padrão de medida plausível para o significado da obra de arte" (GADAMER, 2008, p. 17).

Nesse sentido, o jogo também é uma experiência que, para além da subjetividade do jogador, só pode ser verdadeiramente compreendida a partir do jogar, a partir do momento em que o jogador decide mergulhar nessa experiência e submeter sua subjetividade à natureza do jogo, tal qual ocorre com a experiência da obra de arte.

[...] O 'sujeito' da experiência da arte, o que fica e permanece, não é a subjetividade de quem a experimenta, mas a própria obra de arte. É justamente esse o ponto em que o modo de ser do jogo se torna significativo, pois o jogo tem uma natureza própria, independente da consciência daqueles que jogam" (GADAMER, 2008, p. 255).

É por isso que Gadamer afirma que "o jogar só cumpre a finalidade que Ihe é própria quando aquele que joga entra no jogo" (GADAMER, 2008, p. 155).

Sem lançar-se para dentro dele, sem abrir mão de uma subjetividade pretensamente onisciente, sem aceitar a realidade do jogo como algo à parte, é impossível usufruir de fato dessa experiência.

O jogo se revela apenas no momento de sua vivência. E vivenciá-lo significa aceitar que "o sujeito do jogo não são os jogadores. (O jogo) simplesmente ganha representação através dos que jogam o jogo" (GADAMER, 2008, p. 155). 
Ora, se o jogador não é o sujeito do jogo, e o jogo não é apenas uma projeção da sua subjetividade, então a relação estabelecida entre o jogador e jogo é a inversa do que uma leitura calcada na primazia do Sujeito faria. Não é o jogador que joga o jogo. Pelo contrário, "todo jogar é um ser-jogado. 0 atrativo do jogo, a fascinação que exerce, reside justamente no fato de que 0 jogo se assenhora do jogador" (GADAMER, 2008, p. 160).

Quer seja uma criança brincando com uma bola; quer sejam jogadores de final de semana disputando uma pelada; quer seja uma pessoa caminhando solitária pela praia em busca apenas "das conchinhas rosas"; quer sejam profissionais do xadrez disputando um campeonato, o jogo possui a propriedade de tragar os jogadores para dentro de sua lógica.

Assim, quanto mais joga, mais a criança parece endoidecer com a bola; pacatos pais de família transformam uma improvisada pelada dominical numa luta de vida ou morte; o caminhante solitário chega a refazer o caminho para ver se "não deixou passar uma conchinha rosa" e vários jogadores de xadrez de alto nível utilizam toda sorte de golpes baixos em busca da vitória, como os grandes-mestres Petrossian e Korchnoi, em 1977, em plena competição pelo título mundial, que não hesitaram em aplicar chutes um no outro por debaixo da mesa.

Ao se deixar arrastar para dentro do jogo, uma verdadeira barreira, um "círculo mágico" (HUIZINGA, 2001, p. 13) se erige, se interpõe entre os jogadores, fascinados e enfeitiçados pela realidade do jogo, e os que não participam dessa experiência. Quem já jogou intuitivamente sabe: "todo jogo é capaz, a qualquer momento, de absorver inteiramente o jogador" (HUIZINGA, 2001, p. 11).

Entretanto, mergulhar no jogo, nessa experiência que existe para além da consciência do jogador, obriga aquele que adentra no "círculo mágico" a revestir-se da mais absoluta seriedade e entrega. Ou se entra no jogo, ou não se entra. Não existe meio termo. "Quem não leva a sério o jogo é um 
desmancha-prazeres" (GADAMER, 2008, p. 155) (HUIZINGA, 2001, p. 14), "é um niilista" (CAILLOIS, 2001, p. 7).

Não que o jogador ignore que aquilo é apenas um jogo. Mas é necessário que o jogador suspenda sua noção de realidade exterior, esqueça-a provisoriamente, para usufruir da realidade do jogo. Mas, de que maneira isso ocorre? Quais os mecanismos de funcionamento que fazem com que um jogo arrebate os jogadores para dentro de sua lógica interna?

Para Huizinga, a essência do lúdico está contida na frase "há alguma coisa em jogo" (HUIZINGA, 2001, p. 57). Gadamer coaduna com esse pensamento, ao afirmar que todo jogar, ao menos no jogo humano, é um "jogar-algo" (GADAMER, 2008, p. 161).

O que isso significa? Se alguma coisa está em jogo, isso quer dizer que ela é disputada, permanece incerta, em aberto, aguardando um desfecho. Antes do jogo iniciar, o que existe são apenas possibilidades. Uma bola provoca a criança a acertá-la. A partida de futebol incita seus participantes a descobrir qual dos dois times prevalecerá. A mente da pessoa que passeia na praia a desafia a cumprir a tarefa de coletar as "conchinhas rosas". A partida de xadrez impele seus participantes a se digladiarem, com a promessa de apontar eventualmente um vencedor.

Como uma isca para a inata curiosidade humana, o jogo provoca a subjetividade do jogador com a tentação do êxito, da vitória. Entretanto, ao mesmo tempo, nega-lhe o gozo antecipado de saber se isso de fato ocorrerá. 0 jogo tortura o jogador com a inacessibilidade de seu desfecho. Por isso, o jogo, em essência, nada mais é do que um desafio.

Mesmo quando se trata de jogos em que se procura realizar tarefas que alguém impõe a si mesmo, o atrativo do jogo é o risco de saber se "vai", se "conseguirá" e se "voltará a conseguir". Quem tenta dessa maneira é, na verdade, o tentado. Justamente essas experiências em que há apenas um único jogador demonstram que o verdadeiro sujeito do jogo não é o 
jogador, mas o próprio jogo. É o jogo que mantém o jogador a caminho, que o enreda no jogo e que o mantém nele. (GADAMER, 2008, p. 160)

Ou seja, o jogo, em sua estrutura, opera como uma armadilha para o jogador e para o seu ego. A roda do Destino ali permanece, apenas aguardando que ele aceite o desafio e lhe dê o primeiro impulso.

Entretanto, uma vez aceito o desafio, uma vez que o jogador adentra na realidade simbólica proposta pelo jogo, o que o faz permanecer lá e "ir até o final"? Pois, embora qualquer jogo possua uma meta, uma finalidade que lhe orienta o sentido (quer estabelecida por regras escritas, quer existente apenas na mente daquele que joga, quer complexas, quer candidamente simples), qualquer jogo é obrigado a sustentar, ao menos para o jogador, essa tensão que se estabelece entre seu início e o seu desfecho ${ }^{2}$.

Um jogo desafiador, ao menos para quem dele participa, é aquele capaz de manter a tensão a respeito de sua conclusão praticamente até o momento final. "A dúvida deve permanecer até o fim, [...] até o desenlace" (CAILLOIS, 2001, p. 7).

E como se manifesta essa inquietude? Essa tensão pode ser explicada a partir do conceito de que o jogo opera como um vaivém.

Jogo é movimento. Quando, na natureza, menciona-se, por exemplo, algo a respeito do "jogo das ondas", o quadro mental que se forma é um balanço, um vaivém entre os diferentes movimentos que se pode enxergar no mar naquele momento: as águas calmas após uma vaga; a maré com seu empuxo; uma nova onda que ameaça se formar; a onda formada e pujante; e no após, novamente a espuma indicando tranquilidade.

Por isso, jogo também é repetição, pois os diferentes estados observados fazem parte de um repertório possível. O jogar das ondas é um eterno vaivém,

\footnotetext{
2 Nota do autor: Gadamer argumenta (GADAMER, 2008, pg. 161) que o fim em si do jogo não é a vitória, o desfecho, mas sim a própria ordenação e configuração do próprio movimento do jogo. É um ponto de vista que coaduna com a ideia central de sua tese, que entende o jogo para além da subjetividade do jogador.
} 
cada avolumar-se e esboroar-se das ondas reproduz incessantemente um eterno movimento de repetição.

Finalmente, o jogar, além de movimento e repetição, manifesta-se, em sua expressão unitária, sempre como uma experiência ímpar, pois cada onda, ao quebrar na praia, é singular em sua expressão e desfecho.

O mesmo exemplo pode ser encontrado no caleidoscópio, no bambolê, numa partida de futebol, em qualquer game eletrônico. A estrutura do jogo manifesta-se num vaivém de ações e contra-ações, que se repetem a cada vez que um jogo é acionado. Esse vaivém é o que conduz o jogador através do jogo. E é o que mantém a tensão a respeito de seu desfecho porque, a cada vez, o desenrolar das possibilidades contidas no jogo se manifesta de maneira única.

Na competição surge o tenso movimento do vaivém, do qual resulta o vencedor, fazendo assim com que o conjunto seja um jogo. O vaivém pertence tão essencialmente ao jogo que em sentido extremo torna impossível um jogar-para-si-somente. Para que haja jogo não é absolutamente indispensável que outro participe efetivamente do jogo, mas é preciso que ali sempre haja um outro elemento com o qual o jogador jogue e que, de si mesmo, responda com um contralance ao lance do jogador. É assim que o gato que brinca escolhe o rolo de lã porque este também joga com ele; e os jogos de bola são imortais por causa da mobilidade livre e total da bola, que também de si mesma produz surpresas. (GADAMER, 2008, p. 159)

É por isso que, em suma, o jogo é uma estrutura que compele o jogador ao desafio. É esse vaivém, formado por lance e contralance que se desenrola de maneira imprevisível e única, que explica, em última instância porque, ao se adentrar no jogo, não existe garantia de êxito.

Mesmo que o jogo seja o mesmo e que os parceiros de jogo sejam os mesmos, a cada partida, a cada reinicio, não existe como se reproduzir fielmente o que foi a experiência anterior. Assim como Heráclito dizia não ser 
possível entrar duas vezes no mesmo rio, não é possível experimentar duas vezes a mesma partida. Cada experiência de jogo é ímpar.

E isso também deixa claro qual é a ação fundamental que cabe ao jogador ao longo do desenrolar do jogo. Jogar é, essencialmente, uma ação. Ação porque o jogo, sob o ponto de vista do jogador, como lembra Henriot, é acima de tudo um fazer, é uma atitude ("mettre em oeuvre") (HENRIOT, 1989, p. 300).

Nesse sentido, o jogo clama pelo protagonismo do jogador para que possa se representar. A todo momento, é a ação do jogador que empresta vida à estrutura do jogo, que move suas alavancas, quer fazendo um lance, quer respondendo com um contralance. Não à toa o jogo incita no jogador 0 sentimento de onipotência. Embora independente em sua natureza, para realizar-se como tal o jogo precisa fundamentalmente do jogador para ganhar representação.

E, ao dispor-se a jogar, de fato, toda a responsabilidade sobre o andamento daquele mundo simbólico, daquela experiência que se iniciou com um primeiro movimento, recai sobre o jogador e suas escolhas (insiste-se, isso não torna o jogo dependente da subjetividade do jogador para existir. Não cumprir com as escolhas, dentro da visão de Gadamer, apenas retira o jogador da experiência do jogo. Ele para de jogar).

Tudo isso considerado, propõe-se aqui o seguinte conceito: a escolha é a forma pela qual o jogo acontece. A escolha é o modus operandi do jogo. Através do jogador e suas escolhas é que o jogo se inicia, se desenvolve e alcança seu desfecho. É através da imprevisibilidade contida nesse emaranhado de escolhas e contra-escolhas que o jogo sustenta sua tensão e seu desafio até seu desfecho. É pela configuração única dessas escolhas que o jogo mantém cada experiência como algo sempre singular. É assim que, sob esse ponto de vista, escolher apresenta-se como $o$ ato primordial encerrado no ato de jogar. 


\subsection{O QUE O JOGO SIGNIFICA PARA OS JOGADORES}

A proposta deste capítulo era a de oferecer uma argumentação para as duas proposições explicitadas por Huizinga:, (1) o que é o jogo em si mesmo e (2) o que ele significa para os jogadores. Sobre o que é o jogo em si, ao menos no que tange a seu mecanismo interno de funcionamento, foi oferecida uma interpretação a partir dos conceitos de Gadamer, na qual se ressalta o ato de escolher como o átomo desse processo.

Porém, se o jogo se desenrola sob a égide da escolha, se ela organiza a forma pela qual o jogo se revela para o jogador ao longo da experiência e do desafio de jogar, ainda assim esse modus operandi não é capaz de explicar totalmente as razões pelas quais o jogo é tão apreciado pelos jogadores. Pois o jogo não se manifesta apenas pela sua forma. Ele também provoca sensações a partir dessa configuração, dessa estrutura.

Em outras palavras, o jogo traz embutidas certas propriedades que açulam, provocam, trazem significado para os jogadores. Assim como o jogo joga o jogador, ele também, dentro dessa linha de raciocínio, é ativo ao oferecer àqueles que dele participam os frutos de sua experiência. Assim como o jogador é dominado pelo jogo, ele também é muitas vezes dominado pelas paixões que emergem do jogar.

Por exemplo, a diversão que o jogo provoca é um reflexo do jogo. Não se joga pelo prazer tão somente. 0 prazer é consequência, mas não a razão do jogo.

Uma criança, para brincar, resolve pular do solo para um banco. É certo que ele experimenta algum prazer nisso. Mas não é pelo prazer que ele realiza esse ato. Antes de saltar, ele não consegue supor a quantidade de prazer que obterá de tal ato. Ele não busca o prazer como uma meta. É o ato de saltar que ele busca, não o prazer" (HENRIOT, 1989, p. 180).

Isso reforça a ideia de Gadamer de jogo como um ente em si, jogado pelo que representa em si mesmo. 
Por isso, Heidegger, ao se perguntar por que a grande criança do mundo de Heráclito joga, responde buscando justificar ontologicamente o modo de ser do jogo: 'joga porque ele joga (es spielt). Permanece somente o jogo: o supremo e mais profundo' (GUERVÓS, 2011, p. 55).

As sensações atreladas ao jogar a serem examinadas neste trabalho são três: diversão, fantasia e onipotência. Sua eleição, embora calcada em uma série de considerações que serão expostas a seguir, não esgotam todas as possibilidades. As qualidades que colorem o jogar são, por certo, mais amplas do que essas três apontadas.

Entretanto, elas parecem suficientemente fortes e significativas para comprovar a argumentação geral proposta neste trabalho. Sua maior força, como já dito, é que estão firmemente atreladas aos mecanismos de funcionamento dos jogos.

A escolha dessas variáveis também é reforçada pelos depoimentos dos jogadores de jogos eletrônicos, que têm registrado suas experiências a respeito do hábito de jogar nos fóruns, nos comentários, nos blogs e em quaisquer outros espaços de manifestação encontrados na internet.

É um material precioso, não apenas porque é algo escrito pelos próprios jogadores, mas também porque foi colhido "ao natural", sem nenhuma interferência do pesquisador (salvo eventual seleção e edição). O material não foi tratado quantitativamente, mas sim qualitativamente - os comentários dos jogadores a seguir foram incorporados à argumentação tal qual as citações de autores acadêmicos.

Outro critério que confirmou a escolha dessas três variáveis é o registro que provém de fontes históricas. Comentários sobre o jogo existem desde os primórdios da escrita. Os três aspectos eleitos para o trabalho são consagrados, reconhecidos por diferentes culturas e diferentes grupos retóricos.

Ademais, o uso dessas fontes históricas é importante porque assegura que essas qualidades atribuídas ao jogo não são apenas fruto da visão 
contemporânea do jogar. São visões que podem até ser partilhadas pelos jogadores modernos, e podem mesmo ser propositalmente ressaltadas pela indústria de games, mas estão fixadas desde muito além do período histórico atual.

Ademais, a escolha desses três aspectos está relacionada com sua valoração pelo meio acadêmico. Diversos autores, por exemplo, apontam a íntima relação entre o jogo e diversão, ainda que abrigados em campos retóricos diferentes entre si. Isso é, por si, demonstrativo de que essas qualidades a serem discutidas a seguir perpassam diversas retóricas e merecem ser consideradas.

Finalmente, esses três aspectos serão considerados em separado, mas na experiência de jogo eles se apresentam obviamente entremeados, como atesta o gamer James_Giant_Peach. "Algumas vezes eu jogo games para curtir o desafio, outras vezes pela história, frequentemente eu apenas quero me perder num mundo fantástico que quebre as regras deste aqui" (GIANT BOMB, 2011).

\section{7. - JOGO E DIVERSÃO (FUN)}

No conhecido site sobre games Kotaku (KOTAKU, 2013), os comentários a respeito da matéria "Por que jogamos games?" rendeu comentários reveladores.

O gamer JesusChrist coloca "Eu jogo games porque eu me sinto entediado e eu os acho divertidos".

All Your Base concorda. "Quando estou entediado e não tenho nada para fazer em casa, eu jogo um jogo. Eu acho isso 'menos' perda de tempo. [...] Eu parei de ver filmes ou shows de TV há alguns anos e agora todas as TVs estão plugadas em consoles". 
Knocky acrescenta: "É o fator fun, eu acredito. Eu digo, eu preciso de diversão para não me tornar uma pessoa muito, muito, muito má".

Panama Punk resume: "Tédio. A vida torna-se muito chata sem nenhuma forma de entretenimento, e os games caem nessa categoria".

[A] enxerga algo parecido: "(Jogar) é divertido, eu geralmente jogo para me desconectar do trabalho e de 'obrigações' e também para relaxar um pouquinho, você sabe... mas eu acabo ficando louco! 'CJ, seu estúpido, anda rápido! Vamos Dr. Freeman, dirige direito, e por ai vai".

Ueziel é ainda mais sucinto: "(Jogo) Porque eu gosto de diversão".

Outros sites e fóruns de discussão onde esse tema é levantado apresentam respostas similares (GOTTO, 2013) (PERREAULT, 2014) (THE GAME THEORISTS, 2013). Jogar é comumente percebido pelos jogadores desta época como uma atividade divertida, que traz alegria, espanta o tédio e oferece um alívio às vicissitudes da vida.

Entretanto, esses praticantes de jogos eletrônicos não estão experimentando uma sensação nova. Embora o jogo se apresente através de um meio inédito, eles estão inscritos numa longa e antiquíssima tradição.

Por exemplo, entre 1251 e 1282, sob o comando direto de Alfonso X, o sábio, rei de Leão e Castela, produziu-se a maior joia da literatura medieval sobre jogos, o "Libro de Juegos". O livro dividia-se em quatro seções: a primeira lidava com o Xadrez ("Libro Del Acedrex"), a segunda com jogos de dados, a terceira com o Gamão e suas variações e a quarta com variantes do Xadrez, como o Alquerque (BELL, 1979, p. 16).

Mais de setecentos anos separam esse livro dos jogadores de hoje. Porém, em sua introdução, estão expostas as mesmas constatações.

Deus quis naturalmente que os homens tivessem todas as formas de alegria para que pudessem suportar os desgostos e tribulações da vida, quando the 
sobreviessem. Por isso os homens procuraram muitos modos de realizar com plenitude tal alegria e criaram diversos jogos que os divertissem. [...]

Podem ser realizados de noite ou de dia, como podem também ser praticados pelas mulheres - que não cavalgam e ficam em casa - pelos velhos e por aqueles que preferem ter suas diversões privadamente para não serem incomodados, ou ainda pelos que estão sob poder alheio em prisão ou cativeiro, ou viajando pelo mar.

$E$, para todos em geral, quando há mau tempo e não se pode cavalgar, nem caçar, nem ir a parte alguma e forçosamente têm de ficar em suas casas e procurar algum tipo de jogo com o que se distraiam, se ocupem e se reconfortem. (LAUAND, 1988, p. 24)

O mesmo sentimento que toma os jogadores e o rei Alfonso, o sábio, o filósofo alemão Eugen Fink consegue exprimir com clareza: "Jogar nos deleita. Jogando, conseguimos escapar por um momento do andar cotidiano da vida" (FINK, 2008, p. 18). É por isso que, em sua opinião, o jogo é um "oásis de alegria" em meio ao cotidiano.

É o que também aponta o filósofo francês Allain Cotta, autor do livro "La Société du Jeu". Segundo Cotta, no cenário contemporâneo, a fadiga oriunda do trabalho físico já não exaure a maioria dos homens. Ele afirma que, das motivações pelas quais os homens jogam, a principal seria, sem dúvida, a necessidade imperiosa de lutar contra o tédio ("la menacce d'ennui"). Jogar é uma saída contra a uniformidade da vida social, é uma maneira de contrabalançar o tempo que é dedicado às coisas sérias da vida.

A gamer Cassie Gotto, em seu artigo "Why do we love video games?" exprime isso com objetividade.

Um grande motivo pelo qual nós amamos tanto os video games, eu sinto, é porque eles são um escape de nossas muitas vezes tediosas e monótonas vidas. De vez em quando é legal encarnar um personagem do jogo e esquecer tudo a respeito de nossos problemas.

É bom saber que, após eu ter tido um dia difícil, eu posso chegar em casa, colocar o headset e jogar um bom game. Games de ação-aventura são os 
meus prediletos, porque eu sou sugada para dentro do mundo do jogo e esqueço a respeito de tudo ao meu redor. (GOTTO, 2013)

Como não pensar nos diversos conceitos até agora apresentados? Numa fala simples e direta como essa, percebe-se o isolante efeito do círculo mágico de Huizinga; o jogo como uma entidade autônoma de Gadamer, capaz de sugar o jogador para dentro de sua estrutura; Fink e o jogo como deleite, como um oásis de alegria e diversão, em contraposição ao tédio que domina a vida cotidiana, como aponta Cotta.

E por que os jogos trazem diversão aos que ousam beber de sua água? A alegria e a diversão presentes no jogo talvez estejam no fato de que o jogo demanda a participação ativa do jogador não apenas para que possa se cumprir como tal, mas porque o desfecho específico daquela experiência de jogo (uma partida, por exemplo) é fruto direto das escolhas empreendidas pelo jogador. Nesse sentido, a estrutura do jogo, como ele se dispõe para o jogador, é fundamental para se rastrear a origem dessa sensação.

O jogo, como proposto anteriormente, é essencialmente um desafio, um risco ao jogador. Mas um risco, uma aventura, uma ousadia que traz consigo a efervescência da vida. De um lado, a vida com suas obrigações, vicissitudes, limitações, rotinas e tédio imobilizantes, Ananke (necessidade), ou ainda como Freud (FREUD, 2010) viria posteriormente a definir, Tânatos (pulsão de morte), redução, imobilidade. De outro, o jogo, "a ação espontânea, o fazer ativo, o impulso vital, [...] a existência que se move por si" (FINK, 2008, p. 15), em sua intrínseca imprevisibilidade e turbulência, desafio e conflito, expressão de Eros (pulsão de vida).

"O risco do tédio gira principalmente em torno de uma exigência generalizada da certitude [...] se tudo é previsível, viver passa a ser não mais do que envelhecer". (COTTA, 1993, p. 23).

Em verdade, esse dilema entre a pulsão de vida e a de morte é tão presente no jogador que mesmo se o jogo for pensado em termos heraclíticos, 
que imaginam o jogo como uma disputa irracional, como liberdade sem limites, conflito arbitrário e violento de forças físicas ou ainda como uma manifestação concreta do Destino (SPARIOSU, 1989), ainda assim essa oposição entre Eros e Tânatos se sustenta.

Tome-se a guerra, que é o melhor exemplo do jogo em sua expressão pré-racional. Talvez a guerra não tenha conhecido expressão mais agonística do que nos tempos Homéricos.

$\mathrm{Na}$ sociedade Homérica - e isso é verdade também para os primevos tempos medievais - 0 poder presentificava-se sob a forma de (predominantemente violentos) jogos agonísticos. Isso significa que não apenas a competição tinha uma função crucial na vida Homérica, mas também que o herói grego via esse relacionamento para com outros heróis e mesmo para com os deuses, assim como a existência em geral, nos termos de um imenso jogo de poder. (SPARIOSU, 1989, p. 13)

Nesse sentido, é exemplar a escolha feita por Aquiles, quando decide partir para a guerra de Tróia. Já o adivinho Calcas havia predito: ele teria a opção de uma vida longa, pacata e pacífica, ou então uma vida curta e gloriosa. E mesmo sabendo que sua própria morte estava vaticinada no momento em que decidisse tomar parte no conflito, Aquiles opta pela luta.

Mais, ouve de seu pai Peleu a confirmação de sua escolha, quando o velho o incita: "Seja sempre o melhor e exceda todos os outros", numa epítome do ideal aristocrático grego (aristoi), baseado essencialmente na disputa e no desafio.

Para Aquiles, assim como para os milhões de jogadores anônimos que usufruem do jogo numa dimensão muito mais pacífica, jogar, em seu desafio, turbulência e imprevisibilidade, assemelha-se a Eros, o princípio do prazer, pelejando contra a previsibilidade e banalidade da vida, ancorada no princípio da realidade.

A escolha feita por Aquiles se manifesta nos jogadores de hoje através das madrugadas perdidas em batalhas e aventuras (mesmo que à custa das 
atividades sérias do dia seguinte, como escola ou trabalho), no alheamento social perante amigos e colegas que não se interessam por esse tipo de vivência, na dificuldade de eventualmente partilhar desse universo com o par amoroso, etc..

E talvez isso ocorra porque, ao final, seja preciso pensar no jogo não apenas como uma recreação, como um "intervalo" entre as coisas sérias da vida, mas sim como um aspecto fundamental da vida humana.

Fink é incisivo nisso, quando argumenta que o Homem, em sua condição básica, é um mortal, um trabalhador, um lutador, um amante e um jogador. "Morte, trabalho, domínio, amor e jogo formam o âmbito tensional elementar e a base da enigmática e multívoca existência humana" (FINK, 2008, p. 13). Ao se exercer cada uma dessas coisas, o homem oferece um testemunho de sua humanidade.

"O jogo do homem é a produção, caracterizada pelo prazer, de um imaginário mundo do jogo. É uma maravilhosa joia de 'manifestação"' (FINK, 2008, p. 30). Por essa razão, o jogo não é divertido em função de algo. 0 jogo é, como pulsão de Eros, uma expressão intrínseca da vida. Por isso mesmo, é fundamentalmente capaz de gerar diversão em si.

\section{8. - JOGO E FANTASIA}

Fink ainda atribui uma outra qualidade ao jogo. Dos cinco aspectos fundamentais da existência, o jogo seria o único que opera numa sintonia diferente. Pois enquanto morte, trabalho, domínio e amor manifestam-se dentro do plano da realidade, o jogo se realiza fundamentalmente a partir do campo da irrealidade, da imaginação e da fantasia, perpassando as outras quatro estruturas. 
O mundo do jogo, a rigor, não existe dentro das coordenadas de tempo e lugar do mundo real - mas ele possui seu próprio espaço interno e seu próprio tempo interno. E ainda assim, quando jogamos, transcorremos o tempo real e temos necessidade de um espaço real.

Mas o espaço do mundo do jogo não é contínuo tal qual o espaço que habitamos. $\mathrm{E}$ analogicamente acontece com o tempo. $\mathrm{O}$ estranho ir e vir entre a realidade e o mundo do jogo não deixa clarear qualquer modelo de relação entre o espaço e o tempo que já conhecemos.

O mundo do jogo não é suspenso em um simples reino do pensar. Há sempre um palco cênico real, mas não é uma coisa real entre outras coisas reais.

E todavia esse mundo do jogo tem necessidade de coisas reais nas quais se apoiar. Isso significa que há um caráter imaginário no mundo do jogo que não pode ser explicado como um fenômeno puramente subjetivo (FINK, 2008, p. 29).

Nesse sentido, a percepção de Fink sobre o jogo não é inédita neste trabalho. Ela coincide com Bateson (vide pg. 50), quando ambos enxergam uma intencionalidade peculiar que caracteriza o jogo, para Fink denominada como "tempo e espaço internos".

A visão de Fink também é muito próxima da visão desenvolvida posteriormente por Sutton-Smith, quando, em sua definição do jogo como linguagem, atenta para o fato de que o jogo se caracteriza através de uma sucessiva alteração entre realidade e fantasia. (vide pg. 52)

E também Fink e Sutton-Smith convergem quando percebem o jogo não como algo descolado da realidade, mas sim como um fenômeno que utiliza elementos da realidade em proveito próprio, numa colagem particular. O jogo alude à vida, esquematiza a vida, mas não é vassalo dela (pg. 51).

De qualquer modo, o que parece evidente é que o jogo ocupa uma realidade autônoma (HUIZINGA, 2001, p. 6), diferente da realidade, mas 
também diferente de um simples delírio. Talvez a melhor definição sobre essa condição seja aquela fornecida pelo antropólogo Victor Turner.

Turner, inspirado no termo do antropólogo holandês Arnold Van Gennep, trabalha com o conceito de liminaridade. Liminar, para ele, é um estado transicional, vivido por aqueles que participam de um rito de passagem em sociedades primitivas. De início, o neófito é apartado da vida cotidiana. Durante o ritual, o iniciado permanece num limbo, nessa condição liminar, fluída, transicional. Finalmente, ao sair do rito, retorna à realidade transformado.

Nesse ínterim, nesse breve momento de suspensão das regras cotidianas da vida em que ocorre a experiência ritualística, o iniciado experimenta um estado de inversão dos valores tradicionais.

Macho e fêmea, comida e excremento, humildade e orgulho, silêncio e fala (TURNER, 2011, p. 106). No momento do ritual, diversas oposições são apresentadas simultaneamente, num indicativo de morte de um ciclo e nascimento para outra realidade. Exatamente nessa condição, o iniciado experimenta um estado de anti-estrutura, "porque ela inverte ou dissolve a ordem estrutural normal (e normativa) prevalente no resto da comunidade". Turner mesmo identifica isso como uma forma de jogo, no qual, da desordem, reemerge a ordem. (SPARIOSU, 1997, p. 33).

Nas sociedades modernas, que são agrupamentos em larga escala, difusos em sua coesão social, onde os habitantes são participantes de diferentes tradições e apegados a nenhuma delas de maneira férrea, é impossível reproduzir, a rigor, a experiência liminar, segundo o pensamento de Turner.

Entretanto, ele reconhece que esse fenômeno ocorre de alguma maneira dentro do corpo social contemporâneo. Sua ocorrência é denominada não como um fenômeno liminar, mas sim como um fenômeno liminóide. Para ele, eventos como filmes, shows de rock, arte, operas, procissões e até mesmo revoluções podem ser considerados liminóides. 
Para aqueles que passam por essa experiência de suspensão, o efeito é o de um verdadeiro transe. Entretanto, a diferença fundamental da condição liminar para a condição liminóide é o fato de que, nas sociedades tribais, os ritos de passagem são um elemento obrigatório da vida, ao passo que, nas sociedades contemporâneas, essa é uma condição essencialmente optativa, atrelada à vontade do indivíduo.

Sob esse ponto de vista, o estágio liminóide poderia ser visto como o "espaço-tempo lúdico por excelência" (SPARIOSU, 1997, p. 33). Um espaço governado primariamente pela anti-estrutura, onde os indivíduos se veem livres das amarras que regulam a existência em seu estado normal.

Some-se a isso o fato de que a própria estrutura do jogo, como visto anteriormente, obriga o jogador a escolher constantemente, a interagir, a participar. Isso cria como resultado uma experiência liminóide onde o jogador experimenta uma anti-estrutura através de uma intensa e ativa troca simbólica com a estrutura do jogo. No caso específico dos jogos eletrônicos, esse processo é experimentado com grande vigor.

Como pondera o jogador PassiveKaerenai. "Nenhum outro meio artístico deixa VOCÊ [...] controlar sua experiência escapista. Isto é o que me fascina nos games" (GIANT BOMB, 2011)

O gamer Entroperator, por exemplo, enxerga nesse engajamento fantasioso a chance de experimentar papéis e situações arriscados ou proibidos na vida real.

(Jogo) porque isso me permite fazer coisas que eu não poderia fazer na vida real sem ser preso ou morto. Subsequentemente, você nunca me encontrará jogando um game que tenha como conteúdo algo que EU POSSA fazer (KOTAKU, 2013).

VinnyHiga, no fórum de um site sobre o jogo Counter-Strike (SITECS, 2011), comenta sobre a capacidade fantasiosa dos jogos. "No (jogo) CS:Source eu posso descontar minha bala toda matando os CTs ou TRs por diversão ou 
ser guitarrista de banda (Guitar Hero na veia ;P), pois aí podemos conseguir tudo mais facil pela vida virtual!"

O que fica claro a partir daqui é que jogar - quer o elemento de fantasia presente no jogo seja utilizado para a construção de um tipo imaginário ideal, quer seja um palco para as mais diversas experimentações e desdobramentos da personalidade, quer seja o cenário para a exploração de um mundo imaginário, quer sirva como escape para sentimentos e atitudes coibidos no plano real - é um ato que se faz, em boa parte, significativo para os jogadores, pelo fato de se ancorar, de se estruturar, de ganhar vida a partir da fantasia e da imaginação.

Jogar, não importa o que, é sempre garantia de cruzar os limites da realidade rumo a um mundo governado pela fantasia. Um mundo que permanece, de algum modo, atrelado à realidade, num ir e vir, na fronteira da liminaridade, que não é um delírio, mas que ao mesmo tempo não obedece às leis da realidade (anti-estrutural). Um mundo que demanda obrigatoriamente do jogador a sua presença, suas escolhas, sua atenção e que, dentro de uma lógica internamente definida, responde a essas ações.

Uma maneira muito simples de se perceber o quanto a fantasia é componente fundamental para que o mecanismo do jogo entre em movimento está na atenção dispensada aos componentes que agenciam os jogos. Uma peça, num tabuleiro de xadrez, não é apenas um componente de madeira. Ele é um peão, ou um bispo, ou uma torre, ou uma rainha, ou ainda pode simbolizar o rei.

Numa partida de futebol, a camisa do time, sua "tradição", seus cânticos de incentivo, seus inimigos, seus times co-irmãos, suas estatísticas sobre confrontos passados (que, objetivamente, não significam nada para a partida presente), tudo isso é obra da fantasia, da pura simbolização, e parte intrínseca da experiência de jogar (ou torcer). 
No universo dos jogos eletrônicos, basta ver o cuidado com os gráficos, cenários, animações, efeitos e trilha sonora para compreender a importância da fantasia na estruturação do jogo.

Em suma, é importante perceber que, no jogo, a fantasia é mais do que um elemento que lhe confere sabor. Fantasiar é mais do que simplesmente adensar a experiência de jogo. Fantasiar é condição sine qua non para que o jogo exista. A fantasia é o território onde o jogo, por excelência, se manifesta.

O jogador goldenratio1111 exprime bem isso. Ele gosta de jogar porque:

Posso ir a lugares, ter aventuras, fazer amigos, permanecer em contato, pular de penhascos, escalar prédios, matar dragões, ser um elfo, escolher meu caminho, atirar bolas de fogo, atirar num alvo, jogar uma bomba atômica num povo, matar porcos com pássaros, roubar um carro de um policial, ser um jedi, ser um cowboy, coletar crânios, achar um tesouro, evoluir meu personagem, ouvir o barulho das moedas, escapar de uma masmorra, escolher entre o bem e mal, tornar-me rei, salvar a galáxia e morrer, morrer, morrer, morrer, morrer e viver novamente (REDDIT, 2014).

A fantasia, note-se bem pelo depoimento, não está apenas em sua materialização através da tecnologia. Ela se encontra na disposição do jogador de vivenciar a fantasia.

Ou seja, fantasiar é, para usar a definição de Bateson, uma intencionalidade que estrutura toda a maneira pela qual o jogar se exprime. "Esse prazer pelo jogo é êxtase e abdução numa 'esfera', numa dimensão imaginária, não é só o prazer no jogo, mas prazer pelo jogo" (FINK, 2008, p. 22).

Fantasia, em suma, é uma sensação que se inicia no momento em que o jogador concede ao jogo a primazia simbólica sobre a realidade. Sensação que só se amortece quando o jogador encerra essa experiência liminóide que é o jogar. 


\section{9. - JOGO E ONIPOTÊNCIA}

Todo jogar, como ponderam Gadamer e Huizinga, é um jogar-algo (vide pg. 58). Ou seja, jogar é essencialmente um desafio, um risco para o jogador. Por isso, inevitavelmente, todo jogar traz consigo a expectativa do triunfo, do êxito, da vitória, da conquista.

Isso é válido, utilizando um conceito proposto por Caillois, tanto para formas altamente improvisadas de jogo (paidia) quanto para formas estruturadas, como jogos com regras formalizadas (ludus) (CAILLOIS, 2001, p. 13).

Caillois, por exemplo, pesquisador francês que está para a área de jogos como Jung está para a psicologia, na tentativa de complementar a obra de Huizinga, classifica os jogos em quatro grandes grupos distintos: agon, alea, mimicry e vertigo. Mesmo enxergando em todos esses grupos uma natureza distinta, ele identifica a expectativa do êxito em cada um deles.

Em jogos regidos pelo espírito do agon, como futebol, xadrez, bilhar, o êxito está em subjugar o adversário. Em jogos regidos pela alea, como loterias, roleta e dados, a vitória se expressa através do favorecimento do Destino. Em jogos tomados por mimicry, como o teatro e todas as formas de representação, o triunfo é proporcional à qualidade da imitação. E em ilinx, jogos que envolvem a busca da vertigem - como girar em torno de si mesmo até ficar tonto - o êxito é obtido com a realização do êxtase.

Enfim, todo jogar traz consigo um sentido, um objetivo, uma meta, ainda que, ao final, o que realmente importe seja o jogar em si.

A ideia de ganhar está estreitamente relacionada com o jogo. [...] O que é 'ganhar' e o que é realmente 'ganho'? Ganhar significa manifestar sua superioridade num determinado jogo. Contudo, a prova desta superioridade tem tendência para conferir ao vencedor uma aparência de superioridade em geral. Ele ganha alguma coisa mais do que apenas o jogo enquanto tal (HUIZINGA, 2001, p. 58). 
Na frase acima, Huizinga toca em dois pontos fundamentais relativos ao conceito de onipotência e jogo.

Primeiro, para ele, como fica evidente, o objetivo principal do jogo é simplesmente ganhar, "é o desejo de ser melhor que os outros, de ser o primeiro e ser festejado por esse fato" (HUIZINGA, 2001, p. 58). É um sentimento praticamente infantil, de pura afirmação do ser.

Eu acredito que amo os video games porque eles nos dão um senso de realização. A emoção que você tem quando completa um bom jogo é um sentimento contra o qual é difícil competir. O jogo faz com você se sinta importante, como se você tivesse feito algo certo (GOTTO, 2013).

E, de fato, vencer é um sentimento cobiçado, pois embora o jogo seja em si prazeroso, o modo de ser do jogo é, por sua imprevisibilidade intrínseca e sua vocação para o desafio, um evento tenso. "Esse prazer do jogo é um prazer singular e difícil de compreender. [...] É um prazer que pode carregar em si uma profunda tristeza e um sofrimento abissal, que pode abraçar o tremendo, sempre alegremente" (FINK, 2008, p. 21).

Prova contemporânea de como o jogar tem íntima relação com o desafio em sua forma mais dolorosa é a fixação de certos gamers por jogos assumidamente difíceis, como DayZ.

Nesse game, por exemplo, o jogador deve sobreviver a uma infestação de zumbis. Entretanto, ao contrário da maioria dos jogos eletrônicos, onde o jogador possui "vidas" e em caso de acidente renasce com todos os equipamentos e bônus, em DayZ o personagem morre permanentemente. 0 jogador é obrigado a recomeçar do início, com outro personagem, muitas vezes tendo que jogar novamente durante horas e horas para atingir o nível anterior.

Examine-se o que afirma o gamer Vincent, num artigo intitulado "Por que gostamos de jogos difíceis como Flappy Bird, DayZ e Dark Souls 2:

Quando jogo DayZ, sinto medo também, como se fosse um sobrevivente de verdade, perdido no meio de um mundo pós-apocalíptico, infestado de 
zumbis. Uma bala perdida, uma mordida de zumbi, ou uma simples queda pode matá-lo e fazer perder horas de progresso; DayZ é uma experiência de intensidade enorme. Uma dificuldade e uma brutalidade que fazem de DayZ um dos títulos mais assustadores de todos os tempos" (SOFTONIC, 2014).

Se jogar, de certo modo, é sofrer, então vencer, no primeiro sentido proposto por Huizinga, é pura expressão de poder. O jogar, sob essa ótica, se aproxima de sua vertente pré-racional (SPARIOSU, 1989). Nessa acepção, jogar - e triunfar - é prova de força, de supremacia de potência, para si e para os outros.

Um exemplo histórico da manifestação desse tipo de pensamento está no lema das antigas Olímpiadas: "Citius, Altius, Fortius" (o mais rápido, o mais alto, o mais forte). O jogo, sob esse aspecto, é pura e simplesmente o triunfo dos melhores. E esse espírito se manifesta também hoje, como comprova o gamer Tim Challies:

Video games oferecem o fascínio da realização, o fascínio da grandeza. Nós não jogamos jogos para perder, mas para ganhar. Nós não jogamos jogos para sermos conquistados, mas para conquistar. Nós jogamos para triunfar, para conquistar, para derrubar e vencer, para fazer as coisas que estão muito além da nossa experiência de vida. (CHALLIES, 2013)

Assim, se vencer é expressão de pura potência, considerando que o jogo transporta o jogador para um mundo fantasioso onde o jogo se torna a realidade absoluta, vencer passa a significar mais do que potência. Vencer, dentro do campo do jogo, se traduz virtualmente como onipotência.

Por outro lado, na segunda parte de seu pensamento, Huizinga ressalta que ganhar também é veículo para além do jogo. Nisso, coincide com aquilo que Sutton-Smith aponta ao dizer que o jogo, como linguagem, é uma "forma primitiva de simbolização de motivações subjacentes" (vide pg. 52).

Por conta disso, ao mesmo tempo em que o jogo é expressão de pura onipotência dentro da realidade do jogo, ele também é veículo para uma 
manifestação, senão de onipotência, ao menos de potência, que ecoa para situações para além do jogo.

Eu sei que quando eu venço um jogo desafiador, especialmente sendo mulher, eu sinto como se eu tivesse feito algo que um monte de gente pensa que eu não conseguiria fazer. Infelizmente, ainda há gente que acha que garotas não podem jogar video game (GOTTO, 2013).

No plano coletivo, tal qual no individual, o jogo também é veículo para expressão de potência. A História é pródiga em exemplos que demonstram como um jogo age simbolicamente, refletindo em si a potência de outro jogo oculto, que se desenrola para além daquele jogo em si. As Olimpíadas modernas (e também as antigas) contém inúmeros exemplos de vitórias para muito além das quadras e pistas em que foram disputadas.

Em 1972, a disputa entre Bobby Fischer e Boris Spassky no tabuleiro de xadrez era não apenas uma disputa individual pela primazia, mas também uma expressão da Guerra Fria. Na Índia colonial, o críquete, para os indianos, não era apenas um jogo, mas também é uma afirmação de soberania contra o dominador inglês.

Finalmente, jogar, como já mencionado, incita desde o princípio no jogador o sentimento de onipotência pelo fato de que o jogo precisa fundamentalmente do jogador para ganhar representação. Jogar é, sob esse aspecto, um ato que obrigatoriamente confere importância ao jogador.

Isso é ainda mais verdade no universo dos jogos eletrônicos, onde essa condição de onipotência oferecida pelo jogar é ainda mais - e propositalmente - valorizada, como explica o gamer Digitskies, tentando explicar as razões pelas quais joga.

Nos mundos digitais, nos oferecem uma realidade na qual nós gozamos de controle total. $\mathrm{O}$ universo inteiro gira em torno de nós. Todos os eventos do jogo estão relacionados a nós, e começam e terminam em nós. [...] Adicione-se a isso um pequeno e regular senso de realização disponível nos mundos de jogo e você tem uma droga potente, que subitamente nos coloca 
como vitoriosos e importantes, enquanto nos oferece distração e divertimento. (DIGITSKYES, 2012)

Enfim, se o jogo é um desafio, por todas as razões acima apontadas, o jogo também permanecerá sendo fonte de onipotência para aqueles que nele adentrarem e fizerem do jogo sua provisória realidade.

\subsection{0. - JOGOS ELETRÔNICOS NO CONTEXTO MAIOR DOS JOGOS}

As definições oferecidas sobre o jogo elencadas nas páginas anteriores trabalharam com o jogo no sentido mais amplo possível.

Para encerrar este capítulo, Salen \& Zimmerman (SALEN e ZIMMERMMAN, 2004 , p. 304) fornecem uma visão clara de onde se posicionam os jogos eletrônicos no contexto maior dos jogos.

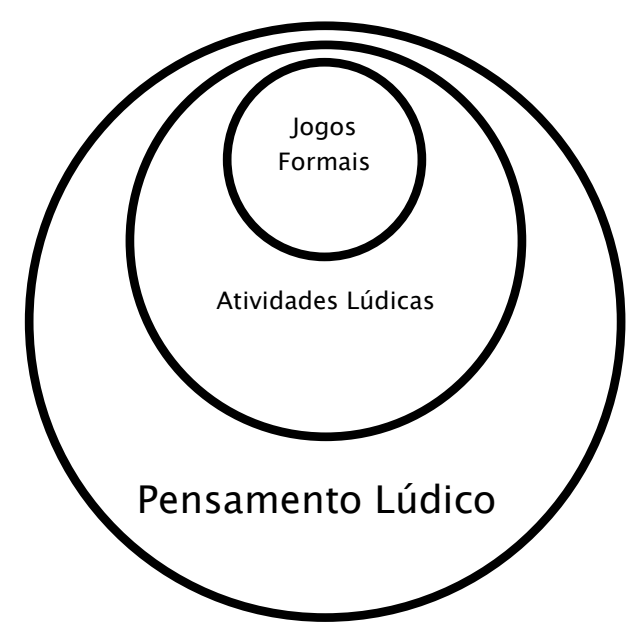

Figura 4: Definição Geral de Jogo (Salen \& Zimmerman)

Para eles, os jogos eletrônicos fazem parte dos jogos que se expressam através de regras formalizadas (Jogos Formais). São jogos que se materializam através de peões, cartas, dados e tabuleiros (jogos de cartas e tabuleiro); ou os representam através de scores, estrelas, bônus, personagens e cenários (jogos 
eletrônicos); ou ainda através de bolas, campos de jogo, traves, tacos e tabelas (esportes). Em geral, são acompanhados de regras escritas e são mais rígidos em sua estrutura.

Entretanto, os jogos formais representam apenas uma pequena parcela daquilo que se denomina, nesse esquema explicativo, de Atividades Lúdicas, que incluem atividades que se expressam sem a necessidade de um esquema formal, como jogar uma bola contra uma parede ou brincar com um bambolê.

Estas, por sua vez, podem ser enquadradas dentro de uma intencionalidade lúdica ainda maior, de um Pensamento Lúdico, que se manifesta nos momentos mais diversos da vida, como andar se equilibrando no meio fio, contar todos os carros azuis que se enxerga na rua ou mesmo sonhar acordado (daydream).

Enfim, os jogos eletrônicos, - embora eles mesmos formem uma grande família, que inclui jogos para PC, para consoles, para celulares, para a web, para outros gadgets como GPS, relógios e televisão, subdivididos em gêneros completamente diversos entre si, como Puzzles, Simuladores de Vôo, Adventures, RPGs, Ação, Estratégia em Turnos, Estratégia em Tempo Real, MMORPGs e outros mais - representam apenas uma fração do grande e elástico clã do jogo que, dependendo da retórica utilizada, pode abrigar em si até mesmo a própria existência.

E embora eles sejam hoje a face mais popular dessa grande família, embora se manifestem num meio até poucas décadas atrás virtualmente inexistente, embora sejam orientados por percepções contemporâneas, os jogos eletrônicos ainda permanecem regidos pela mesma lógica que orienta os jogadores de Mancala, pré-histórico e sofisticado jogo africano, o pai de todos os jogos, que escavam na terra os buracos onde disputam as sementes.

Ambos permanecem um desafio que gera diversão, fantasia e onipotência aos que são tragados por eles. 


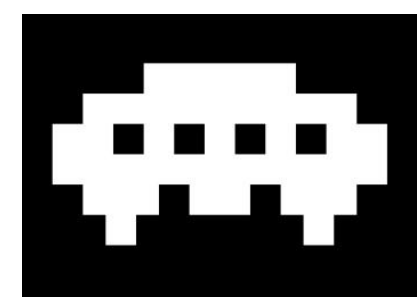

CAPÍTULO III:

\section{AS TECNOLOGIAS DA ESCOLHA}

\section{1. - AS TICS (TECNOLOGIAS DE INFORMAÇÃO E COMUNICAÇÃO) E O JOGO}

O impacto que a digitalização geral provocada pelo computador, somada à disseminação em larga escala das redes mundiais, é de tal grandeza que é comparável, segundo Peter Drucker, ao surgimento das ferrovias, ou então à implantação dos cabos submarinos de telégrafo no século XIX (REDFERN, 2005).

No plano do indivíduo, essa revolução se fez sentir cada vez mais a partir da miniaturização constante ofertada pelas TICs (Tecnologias de Informação e Comunicação) (MIĖGE, 2009). Do computador pessoal aos smartphones, da World Wide Web às aplicações em Nuvens, ao longo destas últimas décadas, a 
ubiquidade com que estas tecnologias se manifestam na vida cotidiana conduziu a relação homem-máquina a um novo patamar. $^{3}$

É o que Sherry Turkle (TURKLE, 1995) argumenta, ao apontar que, no decorrer das últimas três décadas, os computadores assumiram uma função muito maior do que a originalmente pensada. De modernos ábacos, tornaramse máquinas que espelham e complementam o raciocínio. De máquinas de gerar respostas (outputs), tornaram-se máquinas de representação, ou seja, um espaço simbólico onde se projeta a consciência do usuário.

No campo cultural, o impacto dessas novas tecnologias não foi menor do que em outros ramos. Nas palavras de Lunenfeld:

[...] Em um período de tempo impressionantemente curto, o computador colonizou a produção cultural. Uma máquina que estava destinada a mastigar números, começou a mastigar tudo: da linguagem impressa à música, da fotografia ao cinema. Isso fez da cibernética a alquimia do nosso tempo e do computador seu solvente universal. Neste, todas as diferentes mídias se dissolvem em um fluxo pulsante de bits e bytes. (LUNENFELD, 1999)

De fato, as TICs (Tecnologias de Informação e Comunicação) foram extremamente propícias para a ampliação do repertório cultural como um todo. No caso dos jogos não foi diferente. A mediação tecnológica, em suas diversas instâncias, foi e é fundamental no redimensionamento experimentado pelos jogos, na medida em que provocou um repensar das suas possibilidades. Afinal, o componente tecnológico não apenas revitalizou certas modalidades, como também ampliou significativamente as possibilidades dos games, permitindo a criação de novos gêneros e de novas maneiras de se jogar.

\footnotetext{
${ }^{3}$ Ao longo dos séculos, junto com cada revolução tecnológica, o Homem experimentou uma relação dual com as máquinas que o circundavam: por um lado, medo e temor, na medida em que as máquinas aparentemente "realizavam" proezas que sobrepujavam a força ou a inteligência natural do homem, transformando-as num inimigo em potencial. Por outro lado, as mesmas máquinas eram percebidas como amigas, na medida em que ampliavam seus poderes, que the aumentavam a velocidade ou a força. (HUHTAMO, 1999; LUNENFELD, 1999)
} 
As TICs também criaram as condições, através dos inúmeros aparatos desenvolvidos (celulares, consoles, PCs, internet, TV), para que os jogos eletrônicos pudessem ser praticados nas mais diferentes situações do cotidiano. Inclusive, essa simbiose fez com que as indústrias de jogos e as de tecnologia puxassem uma à outra ao limite de suas possibilidades - tecnologias novas foram criadas para acomodar os jogos de última geração, enquanto os jogos de última geração foram criados para as últimas tecnologias disponíveis.

Em última análise, é esse abraço entre os jogos e a tecnologia que permite pensar hoje os jogos eletrônicos não apenas como um entretenimento digitalizado, mas também como um novo tipo de mídia de massa e como um território virtual onde se exerce a socialidade contemporânea.

Entretanto, se é razoavelmente fácil perceber que os jogos encontraram ampla guarida dentro desse contexto tecnológico, nem sempre são perceptíveis as razões pelas quais ocorre essa simbiose. O objetivo deste capítulo é justamente explorar um pouco mais essa correlação.

Janet Murray, em seu clássico "Hamlet no Holodeck: O Futuro da Narrativa no Ciberespaço", lista quatro características fundamentais dos ambientes digitais. Para ela, "ambientes digitais são procedimentais, participativos, espaciais e enciclopédicos" (MURRAY, 2003). As duas primeiras propriedades estão relacionadas com as características interativas do processo, ao passo que as duas últimas referem-se os componentes imersivos, que fazem dos mundos virtuais algo tão explorável e extenso quanto o mundo real.

A partir desse modelo explicativo, que será detalhado adiante, realizar-seá uma superposição dos conceitos que foram levantados ao longo do segundo capítulo (escolha, diversão (fun), fantasia e onipotência). O objetivo, como já dito, é demonstrar em que medida o modus operandi das TICs (Tecnologias de Informação e Comunicação) conjuga-se com certas características fundamentais dos jogos. 


\section{2.- CARACTERÍSTICA PROCEDIMENTAL E ESCOLHA}

O primeiro e mais importante cruzamento entre os jogos e as TICs está relacionado com aquilo que Janet Murray designa como "capacidade procedimental do computador".

É surpreendente que esqueçamos o fato de que o novo meio digital é intrinsecamente procedimental, mas fazemos isso com frequência. Embora falemos de uma "hiperestrada da informação" e de "quadros de aviso" no ciberespaço, na realidade o computador não é, em sua essência, um condutor ou um caminho, mas um motor. Ele não foi projetado para transmitir informações estáticas, mas para incorporar comportamentos complexos e aleatórios. Ser um cientista da computação é pensar em termos de algoritmos e heurística, ou seja, identificar constantemente as regras exatas ou gerais de comportamento que descrevem qualquer processo, desde calcular uma folha de pagamento até fazer voar um aeroplano. (MURRAY, 2003, p. 78).

Ou seja, o que os meios digitais fazem é, essencialmente, gerar respostas (outputs) a partir das escolhas (inputs) feitas pelo usuário, de acordo com um repertório previamente programado.

Claro, existem teóricos, (LAUREL, 2014, p. 5) que enxergam nesse espaço de troca comunicacional entre o Homem e o computador não um "toma lá, dá cá" (input - output), mas sim algo mais rico, algo como um "território comum" (common ground), um lugar onde tanto Homem quanto máquina se relacionam, sincronizando entradas e saídas, ajustando-se aos tempos e dinâmicas de ambos, partilhando de antemão mútuos conhecimentos, mútuas crenças e mútuas suposições.

Como contra-argumento, é de se pensar até onde se pode emprestar vontade a uma máquina e o quanto isso já não é, em si, uma reificação de um processo que, no fundo, opõe em verdade não um Homem e uma máquina, mas sim dois humanos, ainda que de maneira assíncrona e mediada pela máquina: o usuário e o criador do software. 
Entretanto, quer se considere o processo como uma simples questão de ação e contra-ação, quer se considere o processo como algo mais rico, o fato crucial permanece o mesmo. 0 mecanismo primordial é baseado na ação, na escolha do usuário.

Em relação a essas escolhas, não se tratam de escolhas amplas e irrestritas. Trata-se de uma escolha reduzida ao quadro de inputs permitidos e reconhecidos pelo programa. Ou seja, a liberdade de escolha do usuário é, de antemão, parametrizada pelo número de escolhas permitidas dentro daquele programa.

A limitação do repertório não significa, entretanto, o comprometimento da experiência daquele que escolhe, nem que a qualidade e a quantidade das escolhas possíveis sejam pobres ou irrelevantes.

Certos programas, por exemplo, podem oferecer uma margem bastante reduzida de escolhas, mas isso não torna o ato da escolha irrelevante. Em jogos antigos, como o clássico "Enduro", da Atari, o usuário está restrito a poucos movimentos de joystick e ao botão de aceleração. Entretanto, o jogo é reconhecidamente um dos maiores clássicos da história dos video games e um poderoso time-consumer.

Do mesmo modo, programas complexos como o simulador de planilhas Excel, ou ainda, jogos que simulam o funcionamento de aviões, como o "Flight Simulator", oferecem uma vastíssima gama de possibilidades de ação, embora, ao fim e ao cabo, essas ações também estejam limitadas a um certo número de possibilidades.

Já em relação à resposta, quando a finalidade da ação requer exatidão e constância, a resposta será sempre a mesma. Por exemplo, no programa Word, se o usuário teclar a letra "a", a resposta do computador deverá ser obrigatoriamente o surgimento da letra "a" na tela. Em boa parte dos jogos, certos comandos são fixos (chutar, pular). 
Porém, quando a ação requer alguma aleatoriedade na resposta ou possui algum condicionante, apela-se para recursos que envolvam porcentagens e algoritmos. Num jogo como "Civilization V", por exemplo, o resultado dos combates é randômico, obedecendo a um sistema de porcentagens.

A essa altura, o que fica claro é que a característica primordial do modus operandi dos ambientes digitais é o processo de escolha contínua realizado pelo usuário. E é justamente esse um dos motivos pelos quais a transposição dos jogos para o meio digital ocorre com tamanha facilidade, pois ambos têm uma mecânica interna de funcionamento semelhante.

Tanto os jogos quanto o meio digital requerem, como condição sine qua non para o progresso da experiência, que seus usuários façam escolhas. A escolha (do usuário, do jogador) é o combustível que aciona o motor de ambos.

\section{3.- CARACTERÍSTICA PARTICIPATIVA E DIVERSÃO (FUN)}

Dessa primeira característica deriva a segunda propriedade dos ambientes digitais descrita por Murray: ambientes digitais são participativos. Mais do que gerar respostas para determinados comandos, o que os ambientes digitais fornecem, ao menos para o usuário, é a sensação de que há um diálogo em andamento (de fato, em última instância, há: entre o usuário e aqueles que programaram o software).

Nesse fluxo, escolhas levam a outras escolhas, que levam a outras escolhas e assim por diante, formando um vaivém, um jogo de ação e contraação muito semelhante ao modo pelo qual os jogos operam (um jogo de damas, por exemplo, é um vaivém de ação e contra-ação). Para o usuário, há a forte sensação de que o computador reage aos seus comandos, e que a máquina pode ser induzida a determinados comportamentos. 
Um caso clássico que demonstra essa propriedade dos ambientes digitais foi o desenvolvimento do programa ELIZA, escrito por Joseph Weizenbaum no MIT (Massachussetts Institute of Technology) entre 1964 e 1966. ELIZA, talvez a primeira dos chatterbots (robôs de conversação), utilizava um script que se servia das palavras-chaves dos usuários para gerar novas perguntas a eles.

Além disso, em sua modelagem, utilizava princípios da terapêutica Rogeriana. Isto fazia de ELIZA um programa relativamente sofisticado, capaz de fazer com que muitas pessoas achassem que outro ser humano escondido é quem estava respondendo às perguntas. Um exemplo de diálogo:

Paciente: Bem, foi meu namorado quem me fez vir aqui.

Eliza: Seu namorado fez você vir aqui.

Paciente: Ele diz que eu estou deprimida a maior parte do tempo.

Eliza: Lamento saber que você está deprimida.

Paciente: É verdade, eu estou infeliz.

Eliza: Você acha que vir aqui vai te ajudar a não se sentir infeliz?

Paciente: Eu preciso de ajuda, ao menos isso parece certo.

Eliza: O que significaria para você obter alguma ajuda?

Paciente: Talvez eu aprendesse a me dar bem com a minha mãe.

Eliza: Conte-me mais sobre a sua família (MURRAY, 2003, p. 76)

Um grande número de pessoas, incluindo a secretária pessoal de Weizenbaum, solicitou permissão para conversar com a máquina. Nas palavras de Weizenbaum (WEIZENBAUM, 1966), citado por Murray (MURRAY, 2003, p. 77):

"Solicitaram para falar com o sistema em particular e, depois de conversar com ele por algum tempo, insistiram, apesar das explicações [de Weisenbaum], que a máquina realmente os compreendia". Mesmo usuários 
sofisticados, "que sabiam muito bem estarem conversando com uma máquina, logo se esqueciam disso, assim como os espectadores de teatro dominados pela suspensão da descrença logo esquecem que a ação que estão testemunhando não é 'real'"'.

Dessa interação que se desenrola entre as escolhas e as respostas, desse mosaico que vai sendo composto dentro de uma sessão de uso é que emerge aquilo que, no caso dos jogos eletrônicos, entretém, passa o tempo, desafia, em suma, traz diversão (fun).

Essa sensação vivida pelos usuários dos computadores é em si muito prazerosa. Afinal, nos ambientes digitais, as respostas oferecidas às escolhas são imediatamente representadas na tela. Isso, de certo modo, torna o computador um amigo fiel. Ele está sempre pronto a considerar quaisquer comandos do usuário e a oferecer uma pronta resposta. Sob um certo aspecto, essas tecnologias são "companheiras" e "oferecem atenção" a quem é carente dela. De uma maneira muito direta, tornam o usuário o centro inequívoco das ações dentro do processo, ainda mais quando esse processo, nas palavras de Laurel, não é um processo relacionado à produtividade, mas sim ao plano experiencial, como é o caso dos jogos (LAUREL, 2014, p. 32).

Claro, quando se menciona comandos e respostas, nem sempre isso significa uma interação textual, como no caso de ELIZA. Pelo contrário, mesmo nos primeiros jogos eletrônicos, criados nas décadas de 50 e 60, na maior parte das vezes esse fluxo de comandos e respostas já se desenrolava através de uma representação gráfica.

Ou seja, as ações desenvolvidas pelo jogador ganhavam corpo através de ícones, que alteravam sua presença na tela conforme os inputs gerados pelo jogador. Mas ainda que o fato de existir uma representação gráfica ajude a criar a sensação de "suspensão da realidade" para as ações realizadas, não é este o elemento crucial que promove a sensação de diversão no jogador. 0 que mantém a tensão do jogo é o seu desenrolar a partir das ações propostas pelo jogador. 
Um caso que ilustra bem essa proposição, e também demonstra como se deu essa simbiose entre ação (escolhas do jogador) e a estrutura operacional dos ambientes digitais com o fim de produzir diversão, é a maneira como surgiu o game "Spacewars!", em 1962, nos laboratórios do MIT.

Nesse jogo existe um sistema de representação gráfica: o jogador controla uma espaçonave que flutua em pleno espaço. A espaçonave move-se a partir do uso de teclas direcionais. Conforme surgem outras figuras na tela, o jogador pressiona uma outra tecla, responsável por "atirar" contra a nave inimiga. Para um dos designers do jogo, "Spacewars!" era a "coisa natural" a ser feita, quando eles tentavam integrar certos scripts de direcionamento bidimensional com a tela disponível.

Por que Spacewars! era a coisa "natural" a ser feita com esta nova tecnologia? Por que não construir um gráfico em forma de pizza, um caleidoscópio automatizado ou um desktop? Seus designers identificaram a ação como o ingrediente-chave, e conceberam Spacewars como o jogo capaz de proporcionar um bom balanço entre o pensar e o agir para os jogadores. Eles enxergaram o computador como uma máquina naturalmente feita para representar coisas que você pode ver, controlar e se entreter. Seu interessante potencial reside não simplesmente na habilidade de executar cálculos, mas em sua capacidade para co-criar e representar ações das quais os humanos participem (LAUREL, 2014, p. 1)

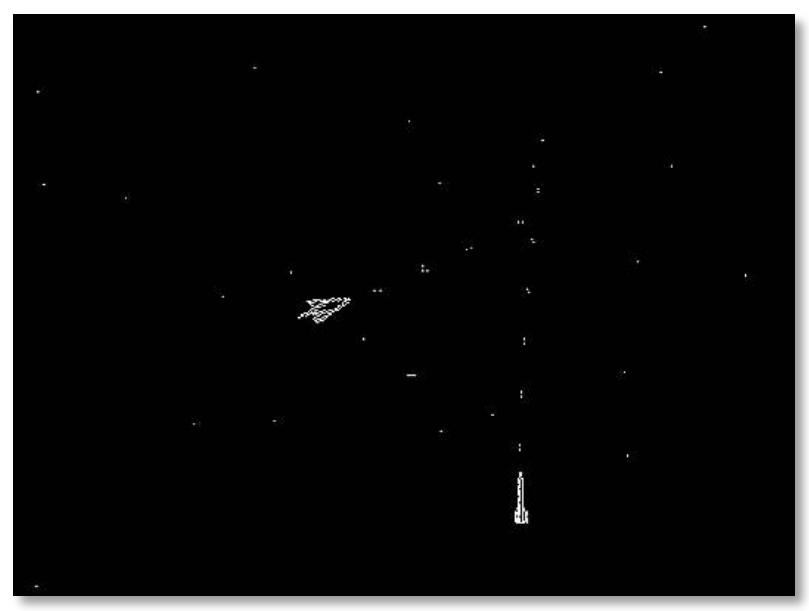

Figura 5: game "Spacewars!" 


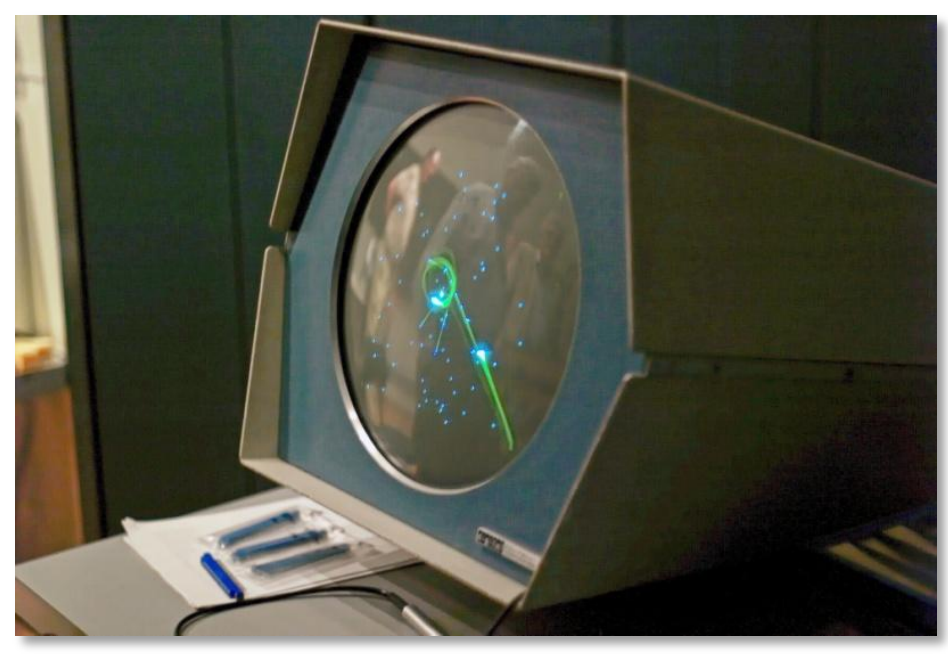

Figura 6: "Spacewars!", visto a partir de um monitor da época

Ou seja, é a capacidade de agir, de escolher, de decidir, o elemento-chave que regula a diversão nos jogos produzidos para os ambientes digitais, tal qual em qualquer tipo de jogo, como já visto anteriormente.

Um exemplo que demonstra exatamente essa confluência entre escolha e diversão está no jogo "Zork", um jogo de texto inspirado no popular sistema de RPG "Dungeons \& Dragons", criado em 1977 por hackers do MIT. Nele, o jogador é conduzido por uma masmorra, através somente de descrições de texto, enfrentando monstros e coletando tesouros.

Ao longo do jogo, o participante possui diversos momentos de escolha. Ele pode coletar determinados itens, escolher caminhos, enfrentar ou não certos monstros. Não há uma única representação imagética (à exceção das letras), mas isso não impediu "Zork" de tornar-se uma febre nas universidades norteamericanas no final dos anos 70, nem de gerar várias continuações.

Para Murray, o segredo de "Zork" era justamente seu foco em criar um sistema de escolhas relevantes para o usuário, qualificando sua participação:

Zork centrava-se na experiência do participante, daquele que se aventurava através de tão inteligente sistema de regras. Zork foi concebido para dar ao jogador a oportunidade de tomar decisões e vivenciar dramaticamente suas consequências. Se não pegar o lampião, você não verá o que há no porão e 
será, certamente, devorado pelo monstro. Mas o lampião não é suficiente. Se você não levar um pouco de água, morrerá de sede. Se beber da água errada, no entanto, será envenenado. Se não levar armas, não terá como combater os trolls. Mas se levar objetos demais, não será capaz de carregar o tesouro quando o encontrar. Para ter sucesso, você deve orquestrar cuidadosamente suas ações e aprender com repetidas tentativas e erros (MURRAY, 2003, p. 82)

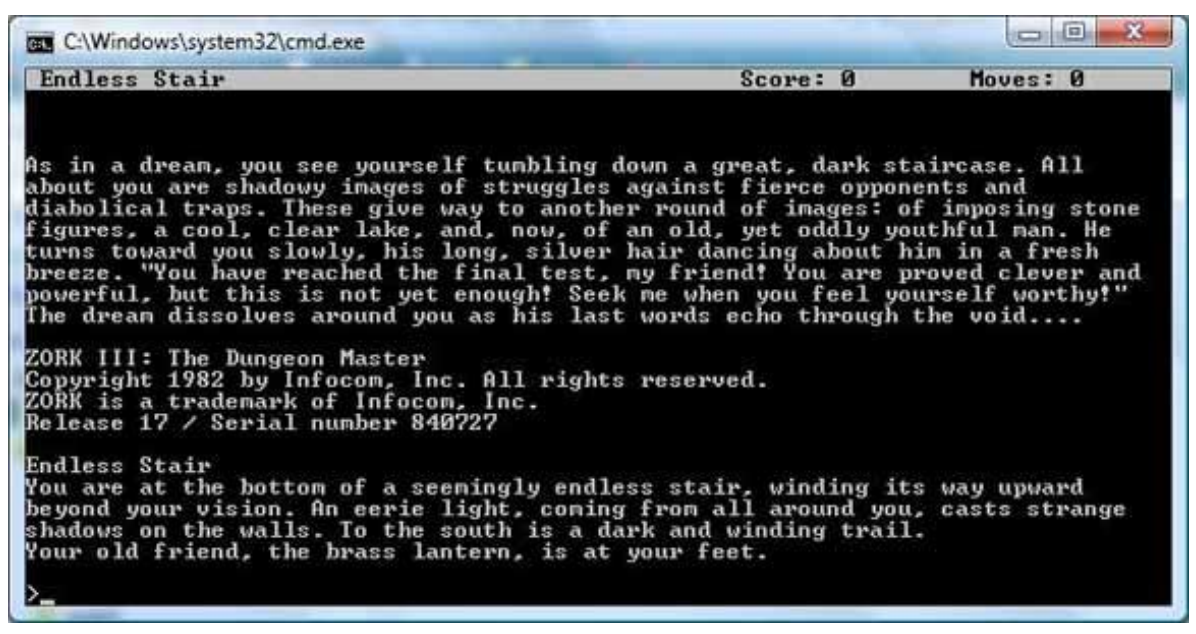

Figura 7: Imagem do jogo Zork III

Finalmente, um outro modo de verificar como a diversão nos jogos eletrônicos tem na ação (escolhas) seu fator preponderante é analisar o comportamento dos jogadores diante do processo de "masterização das regras".

No início de qualquer jogo, o jogador vai gradativamente dominando seus mecanismos, suas regras. Em determinado momento, atinge o auge de sua performance e é capaz de desempenhar à perfeição (zerar o jogo). Em seguida, o que acontece é um declínio do interesse por parte do jogador.

Mesmo excelentes jogos, especialmente quando jogados no modo single player (humano vs máquina), tendem a ser abandonados gradativamente, na medida em que as ações possíveis já foram dominadas de tal forma que o repertório de respostas do software não causa mais surpresa.

Em outras palavras, a diversão é intensa enquanto as reações oferecidas pela máquina desconcertam, desafiam, provocam a inteligência - e diminui na 
medida em que as escolhas propostas pelo jogo perdem sua relevância (por conta da repetição de padrões que já foi dominada e exaurida pelo jogador, roubando-lhe o sabor do desafio) ${ }^{4}$.

\section{4.- CARACTERÍSTICA ESPACIAL E FANTASIA}

A terceira característica dos ambientes digitais mencionada por Murray está relacionada à sua qualidade espacial. Em outros termos, os novos ambientes digitais caracterizam-se pela capacidade de representar espaços navegáveis.

Em oposição aos meios lineares, como livros e filmes, que descrevem espaços (quer através da imagem, quer através da escrita), os ambientes digitais são capazes de algo além: eles permitem ao usuário a sensação de se mover, de percorrer, de caminhar e de interagir pelos espaços propostos na tela (MURRAY, 2003, p. 84). É essa qualidade que dá sustentação ao termo "ciberespaço", porque ela realmente provoca no usuário a sensação de estar posicionado geograficamente em algum lugar, ainda que esse lugar seja a tela que serve de interface.

A qualidade espacial do computador é criada pelo processo interativo da navegação. Sabemos estar numa determinada situação porque, quando acionamos uma tecla ou o mouse, o que a tela exibe (texto ou gráfico) é alterado conforme nossa ordem (MURRAY, 2003, p. 85)

Na construção desse espaço, há que se pesar também a conjunção entre a revolução promovida pela digitalização das mídias e a irrupção de um modelo

\footnotetext{
${ }^{4}$ Nota do autor: A experiência de jogar um jogo eletrônico contra/com outra pessoa possui uma dinâmica diferente. $\mathrm{O}$ jogo, mesmo com as regras e possibilidades aprendidas (masterizado), exerce a mesma função que um tabuleiro no mundo físico. Ele torna-se um palco, uma plataforma, onde dois ou mais seres humanos interagem, restritos, claro, às regras condicionadas pelo sistema. Neste caso, a exaustão do jogo como diversão estaria ligada a outros fatores extra-máquina (tédio em relação àquele sistema de jogo, concorrência de outros jogos, etc.)
} 
de distribuição de dados digitais a partir da evolução das TICs.

A aliança entre esses dois elementos lançou as sociedades que dela usufruem num processo vigoroso de redimensionamento das possibilidades de interação entre as pessoas, e destas com o todo social, quer seja pela desmaterialização do eu, pela alteração dos conceitos de tempo e espaço, ou mesmo por uma nova forma de mapear relações, onde preponderam as proximidades erigidas em cima de valores comuns mais do que em proximidades geográficas.

Ou seja, mais do que unir sistemas que antes operavam separados, as TICs permitiram que os indivíduos passassem a enxergar a tela de seus computadores não apenas como espaço onde imputavam dados em softwares, mas sim como "lugar" de interação com outros indivíduos e grupos.

Um espaço que foi sendo desvendado e, ato contínuo, colonizado pelos seres humanos, que estenderam também para essa arena o seu jogo social, no que Miége denomina um "enraizamento" das tecnologias (MIÈGE, 2009, p. 22). É o que Lemos também observa, ao comentar a forte tendência socializante dessa revolução tecnológica.

As tecnologias do ciberespaço vão potencializar a pulsão gregária, agindo como vetores de comunhão, de compartilhamento de sentimentos e de religação comunitária. No ciberespaço, a maior parte do uso deve-se a atividades socializantes como chats, grupos de discussão, listas, MUDs, icq, entre outros. Na cibercultura, o ciberespaço é uma rede social complexa, e não somente tecnológica. (LEMOS, 2004, p. 86)

Naturalmente, a apropriação desse novo território não foi e não é um evento pacífico, uma vez que essas tecnologias provocaram um rearranjo não só na maneira como o espaço poderia ser concebido, mas também no modo como o tempo poderia se estruturar, como salienta Castells: 
O novo sistema de comunicação transforma radicalmente o espaço e o tempo, as dimensões fundamentais da vida humana. Localidades ficam despojadas de seu sentido cultural, histórico e geográfico e reintegram-se em redes funcionais ou em colagens de imagens, ocasionando um espaço de fluxos que substitui o espaço de lugares. O tempo é apagado no novo sistema de comunicação já que passado, presente e futuro podem ser programados para interagir entre si na mesma mensagem. $O$ espaço de fluxos e o tempo intemporal são as bases principais de uma nova cultura, que transcende e inclui a diversidade dos sistemas de representação historicamente transmitidos: a cultura da virtualidade real, onde o faz-deconta vai se tornando realidade (CASTELLS, 2002, p. 462)

E embora essa qualidade espacial seja fruto do processo interativo em si, o crescente e extensivo uso de representações imagéticas, bem como o uso de diversos efeitos sonoros, só fez aumentar e reforçar a sensação espacial dos meios digitais, pois materializou ainda mais as ações tomadas pelo usuário.

Exemplo cabal disso é a "invenção do desktop", hoje um elemento padrão em qualquer interface digital. O desktop, ou em português "Área de Trabalho", com toda a noção de espacialidade que ele carrega, foi criação dos pesquisadores da Xerox, no "Palo Alto Research Center", na década de 70 (MURRAY, 2003, p. 85). Seu objetivo: simular uma mesa de escritório dentro do espaço da tela.

A primeira companhia a popularizá-lo foi a Apple, em 1984. Segundo Turkle (TURKLE, 1995, p. 34), com o lançamento do Macintosh, que utilizava esse conceito, uma importante barreira foi rompida: pela primeira vez, a linguagem de computação não se apresentava ao usuário comum como uma tela de comando onde eram imputadas palavras.

Ao invés disso, uma nova forma de interação dava seus primeiros passos. Na tela, o usuário via uma simulação, uma metáfora de um ambiente de trabalho. E além de um ambiente muito mais amistoso de operações, a máquina ganhava contornos de personalidade: enquanto o processador 
executava as funções dadas, um ícone de um pequeno computador surgia na tela e sorria. Para Turkle, encontra-se aí a pedra fundamental da aproximação entre o usuário e a máquina, que é quando seu sistema de representação torna-se mais "humanizado".

Daí em diante, o que ocorreu foi uma colonização em larga escala desse novo plano simbólico "humanizado". Imagens, animações e sons cada vez mais sofisticados passaram a povoar toda a experiência de navegação através dessa plataforma digital. Das notas musicais da inicialização do sistema Windows, passando pelo toque do celular Nokia, pela página inicial do Google ou ainda pelo design inconfundível das telas da Apple, é fácil vislumbrar em que medida os recursos multimídia e a capacidade espacial do computador povoaram a mente dos usuários dos meios digitais.

No caso específico dos games, a qualidade espacial dos meios digitais, somada à capacidade cada vez maior de representação imagética e sonora, foi responsável por não apenas materializar os antigos tabuleiros no plano digital, mas por ultrapassar largamente qualquer outra tentativa de representar o mundo simbólico e onírico, matéria-prima sobre a qual se assentam os jogos.

Um clássico exemplo de como esta aliança entre a capacidade espacial e os recursos de animação, ilustração e som se materializaram na representação dos antigos jogos de tabuleiro está no game "Battle Chess", da Interplay/Blizzard, lançado originalmente em 1988 (e do qual derivaram inúmeros outros games ao longo das últimas três décadas). 


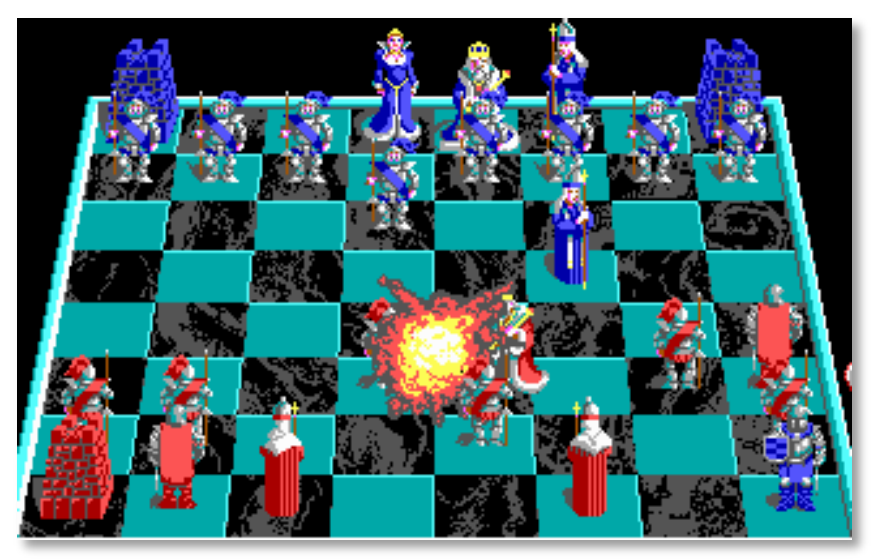

Figura 8: Interface do jogo Battle Chess

O game era basicamente uma simulação de uma partida de xadrez, e podia ser jogado tanto contra o computador (single player) quanto contra um adversário humano (two players).

A originalidade desse jogo não estava apenas na capacidade do computador em conduzir uma partida de xadrez com razoável maestria, nem em materializar esse espaço através da representação de um tabuleiro de xadrez dentro da tela. O maior mérito desse game estava no fato de que ele conseguia, de alguma maneira, reproduzir o espaço psicológico dos jogadores de xadrez.

De que modo isso ocorria? Através de trinta e cinco bem-humoradas animações, que ofereciam uma versão imaginária do que ocorria quando uma peça era tomada por outra peça durante a partida. Assim, quando a Torre, por exemplo, se movia para atacar um peão adversário, o usuário via uma animação na qual a Torre se transformava num monstro de pedra, que caminhava até o peão adversário e o esmigalhava com um golpe na cabeça.

Outras animações faziam referência a elementos da cultura pop da época. A luta entre Cavalo versus Cavalo reproduzia uma cena do filme "Monty Phyton e o Cálice Sagrado" (1975). A luta entre o Bispo e o Cavalo fazia alusão ao filme "Indiana Jones e os Caçadores da Arca Perdida" (1981). 
O brilhantismo do jogo, em resumo, não estava apenas na capacidade de utilizar o computador para simular o espaço de um tabuleiro convencional, mas sim na capacidade de, como pontua Sutton-Smith, aludindo à realidade sem se tornar escravo dela, fantasiar uma luta entre as peças do xadrez, algo que existe desde sempre no imaginário coletivo em relação a esse jogo. Que criança nunca imaginou uma cena de combate entre as diferentes peças de xadrez?

O que fica evidente neste exemplo é que os meios digitais forneceram aos jogos (como também ao cinema, à fotografia e à música) os tijolos para materializar qualquer coisa. E a tela e as interações que nela ocorrem não constituíram apenas um espaço. Mais que isso, essa capacidade espacial configurou-se como um espaço livre, um "mapa sem território" (BAUDRILLARD, 1991), obrigado a ser verossímil apenas em relação à subjetividade e à imaginação dos programadores e à fantasia daqueles que jogam.

Em outras palavras, essa propriedade espacial dos meios digitais tornouse o condutor através do qual o elemento de fantasia inerente aos jogos ganhou uma imensa liberdade de representação.

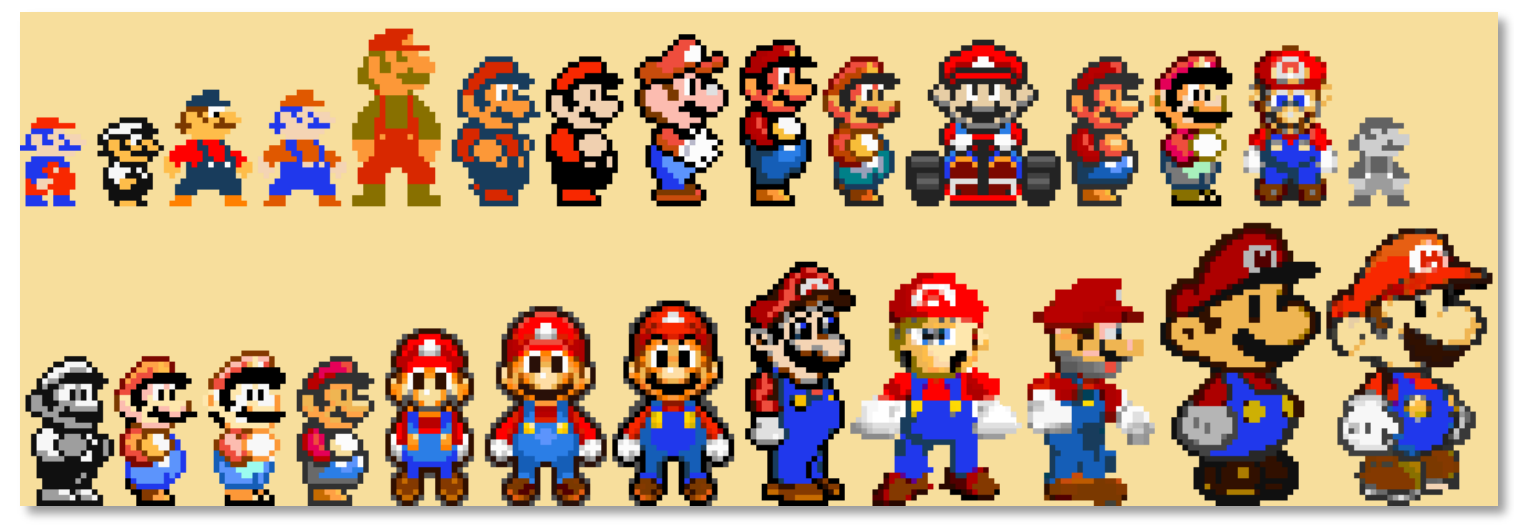

Figura 9: representações do personagem Mario ao longo dos anos, em diversos games diferentes.

É assim que gerações e gerações de gamers foram apresentados aos mais insólitos personagens, como o encanador Mario, maior símbolo da Nintendo e considerado o personagem mais venerado de todos os tempos, de acordo com 
o Guinness (KOTAKU, 2011); ou o porco-espinho Sonic, da SEGA; ou ainda o Pac-Man, uma bolinha comedora de bônus. Isso fora os heróis clássicos, como Link, de "Legend of Zelda"; ou Lara Croft, a sensual heroína a la Indiana Jones; Solid Snake, de Metal Gear ou Master Chief, de Halo.

O mesmo raciocínio se aplica aos cenários. Há uma quase infinita variedade de temas e mecânicas nos jogos eletrônicos. Ao longo dos últimos quarenta anos, tem-se demonstrado prolífica a união entre a qualidade espacial dos ambientes digitais e a capacidade de estimular a fantasia, uma das características fundamentais dos jogos.

\section{5.- CARACTERÍSTICA ENCICLOPÉDICA E ONIPOTÊNCIA}

A última das quatro propriedade dos ambientes digitais advogada por Murray é a qualidade enciclopédica, para ela nem tanto uma diferença de espécie, mas sim uma diferença de grau em relação à qualidade espacial.

Essa qualidade emerge a partir do fato das TICs terem se desenvolvido como o meio de maior capacidade de armazenamento de informação jamais inventado. A quantidade de informação disponível nas redes e nos computadores é de tal modo gigantesca que, para a medida da experiência humana, ela é infinita. Entretanto, afirma Murray, tão importante quanto a enorme capacidade de armazenamento dos meios eletrônicos é a expectativa enciclopédica que eles produzem.

Uma vez que toda forma de representação está migrando para o formato eletrônico e todos os computadores do mundo são potencialmente acessíveis entre si, (...) é como se a versão moderna da grande biblioteca de Alexandria, que continha todo o conhecimento do mundo antigo, estivesse a ponto de se rematerializar na vastidão infinita do ciberespaço. Naturalmente, a realidade é muito mais caótica e fragmentada: as rotinas de busca são, com frequência, intoleravelmente enfadonhas e frustrantes; e a informação 
que desejamos muitas vezes parece dolorosamente fora de alcance. Mas quando ligamos nosso computador e iniciamos nosso navegador na web, todos os recursos do mundo parecem acessíveis, recuperáveis, imediatos. Trata-se de um reino em que facilmente nos imaginamos oniscientes" (MURRAY, 2003, p. 88).

Oniscientes e também onipotentes. A qualidade enciclopédica traduz-se, no jogo, como uma cada vez maior capacidade da máquina em oferecer aos jogadores situações de jogo cada vez mais complexas, nas quais o efeito é um poder de mando muito além da capacidade humana real.

Um bom exemplo disso está nos jogos da série SimCity. Nele, o jogador torna-se o prefeito de uma cidade. É ele quem deverá planejar uma série de aspectos de uma pequena cidade, desde o momento em que ela não é mais do que vila, até o ponto em que se assemelha a uma grande metrópole.

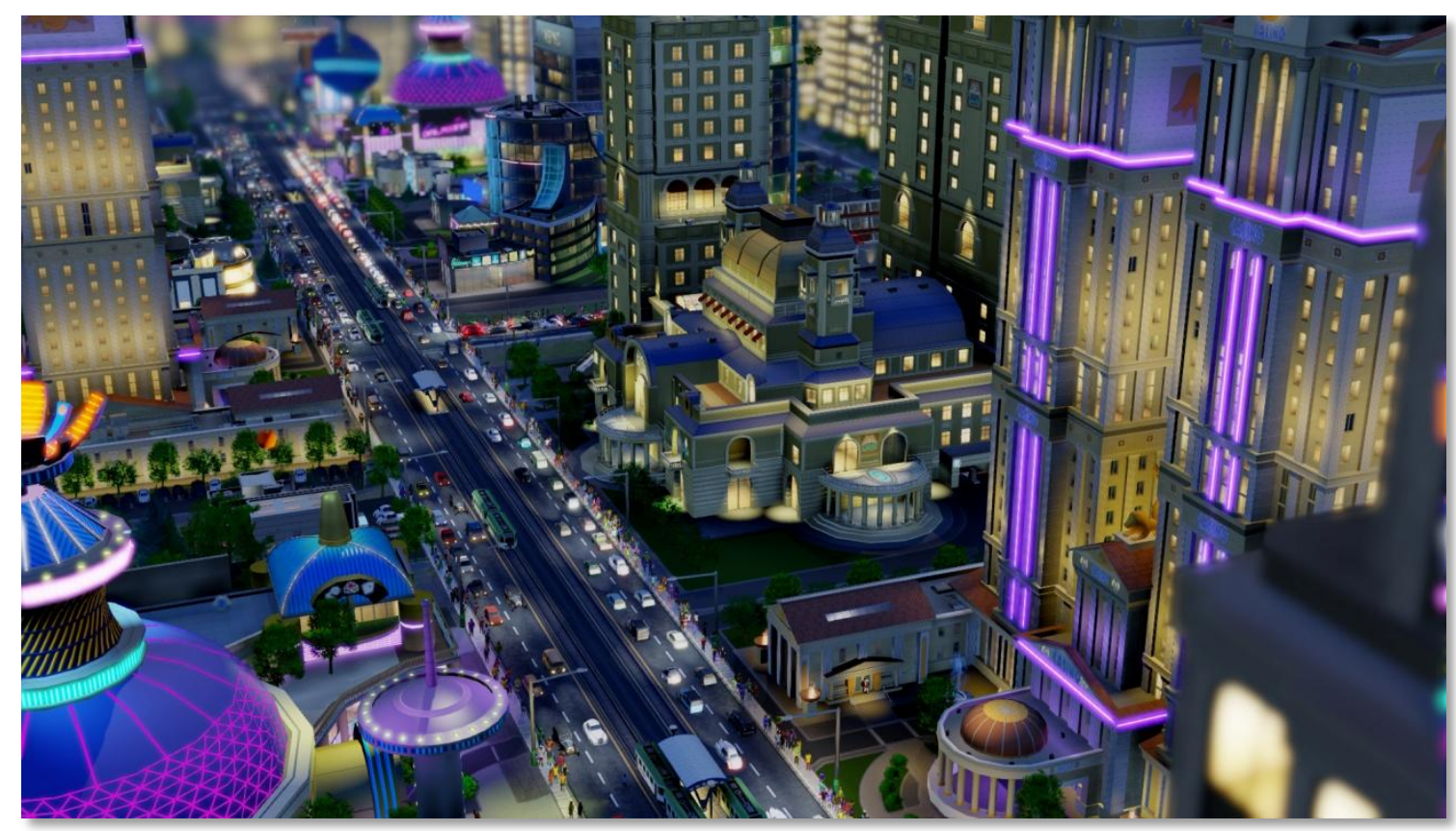

Figura 10: imagem do game SimCity 
Não existe um roteiro definido sobre o que deve ser feito, quais prédios e serviços devem ser implementados, nem por onde devem ser feitas as ruas. Entretanto, por trás do jogo, operam algoritmos que reagem às medidas tomadas pelo jogador, além de acrescentar certos eventos randômicos, como enchentes, terremotos, etc. Como resultado, políticas equivocadas trazem problemas, como manifestações, aumento da criminalidade e congestionamentos. Boas decisões são premiadas com prosperidade e felicidade para os habitantes. O sentimento de onipotência subjaz durante toda a experiência de jogo, como percebe Murray:

Por causa da importância do papel que representa em SimCity, o poder do prefeito assemelha-se mais ao de Deus do que ao de qualquer líder político da vida real, e a sensação experimentada pelo jogador, de onisciente percepção das consequências e de onipotente controle dos recursos, faz parte da fascinação que tais jogos despertam (MURRAY, 2003, p. 91).

Em outras palavras, esse aspecto enciclopédico estimula o sentimento de onipotência porque exemplifica a capacidade cada vez maior dos meios digitais em oferecer ambientes de jogos cada vez mais vastos, complexos e interativos.

Em termos comparativos, enquanto um jogo como Space Invaders era uma experiência limitada a um conjunto simples de procedimentos, realizados de forma individual (single player) e representados na tela por poucos pixels, apoiados por efeitos sonoros quase precários, os jogos atuais traduzem essa experiência de forma muito mais complexa.

O jogo GTA 5 (Grand Theft Auto), um game de aventura envolvendo roubo de carros e o submundo do crime, talvez seja o melhor exemplo para demonstrar como a capacidade enciclopédica é capaz de estimular o sentimento de onipotência.

Produzido pela RockStar para ser um jogo extremamente aberto, GTA não apenas quebrou o recorde como o jogo que mais vendeu, mas também o de jogo mais rapidamente vendido. Em apenas três dias, ele já havia gerado mais de US\$ 1 bilhão em vendas (WIKIPEDIA, 2014). 


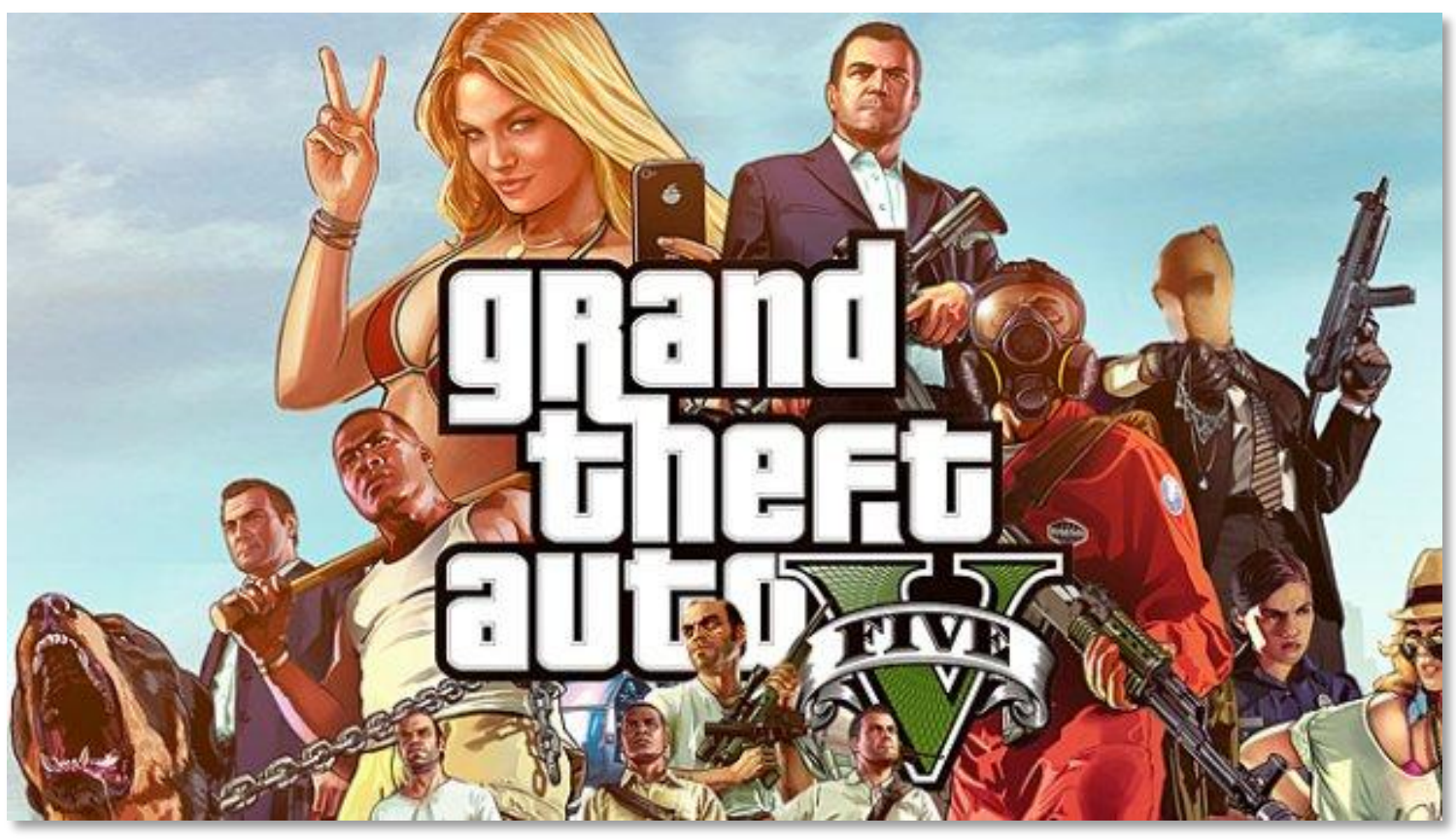

Figura 11: pôster sobre o jogo GTA V

O game impressionou a crítica pela infinidade de detalhes presentes durante o transcorrer das missões. Abaixo, seguem cinco delas, dentre as 100 listadas pelo site especializado IGN (IGN, 2013).

a) Ao repetir uma missão, o jogador encontra diálogos ligeiramente diferentes das vezes anteriores (os personagens não dizem sempre as mesmas falas).

b) No aeroporto, se o jogador entrar no táxi que outro personagem já estava esperando, o personagem irá gritar com o jogador e tentará iniciar uma briga.

c) Se o jogador gastar dinheiro bastante customizando seu carro, pedestres nas ruas elogiarão o carro e tirarão fotos dele.

d) Personagens do jogo procurarão abrigo e cobrirão a cabeça quando começar a chover.

e) O carro do personagem fica gradativamente sujo, especialmente após enfrentar trechos off-road. E personagens do jogo comentarão, se acharem que o carro está muito sujo. 
Embora essas pequenas características não alterem o roteiro principal do jogo, elas potencializam a experiência dos jogadores, já que lhes oferecem mais coisas para fazer. Quanto mais coisas possíveis de serem feitas, maior a demonstração de onipotência do jogador dentro do jogo.

Outra maneira como essa maior capacidade de ser e fazer possui relação com a onipotência está no jogo "World of Warcraft", da Blizzard. A força deste game está no fato de conseguir congregar, em seus servidores, milhões de jogadores simultaneamente, criando um verdadeiro "mundo virtual" (MMORPG Massive Multiplayer Online Role-Playing Game).

Atualmente, existem servidores para atender o Brasil, os Estados Unidos, a Oceania, a Europa, a Rússia, a China, a Coreia do Sul, Taiwan e o Sudeste Asiático, somando um total de 10,2 milhões de jogadores (WIKIPEDIA, 2014).

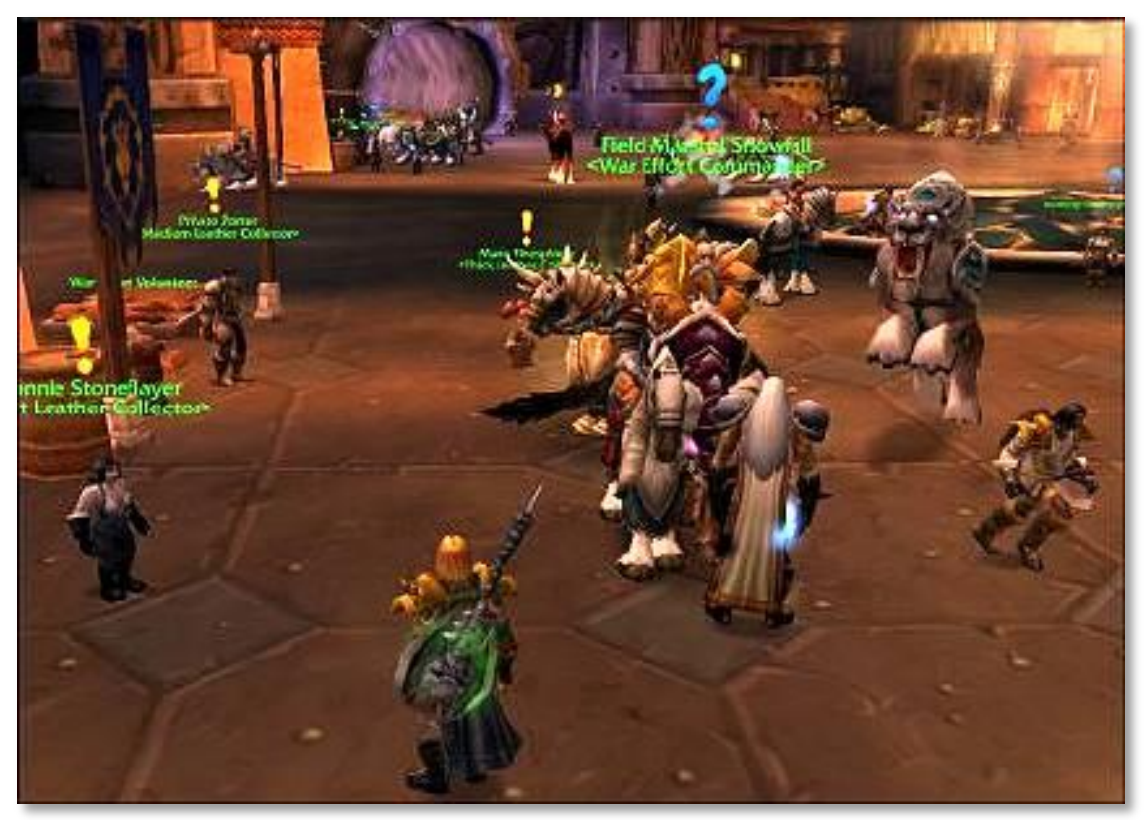

Figura 12: Personagens interagem em World of Warcraft 
Nesse mundo de fantasia medieval, os jogadores escolhem uma facção (Horda ou Aliança), uma raça (Orcs, Renegados mortos-vivos, Trolls, Elfos Sangrentos, Taurens, Goblins, Humanos, Anões, Elfos Noturnos, Gnomos, Draienes e Worgens), uma classe (Druida, Caçador, Mago, Paladino, Sacerdote, Ladino, Xamã, Bruxo, Guerreiro, Cavaleiro da Morte e Monge) e ainda uma profissão (Alquimista, Costureiro, Coureiro, Esfolador, Encantador, Engenheiro, Ferreiro, Herbalista, Joalheiro, Mineiro e Escrivão). A combinação dessas variáveis é capaz de criar uma imensa variedade de seres virtuais, cada um guiado pela vontade de um jogador.

Aqui, a onipotência é fruto da operacionalização e sincronicidade entre um volume significativo de jogadores, das inúmeras possibilidades de composição dos personagens, da possibilidade de exploração de vastas paragens, bem como das largas possibilidades de interação entre os jogadores.

Enfim, é certo que as TICs (Tecnologias de Informação e Comunicação) são condição estrutural da expansão massiva dos jogos. E é tácito que os jogos encontraram dentro do meio digital um ambiente extremamente favorável para se redimensionarem.

Entretanto, se a maneira pela qual operam os meios digitais é propícia a um vigoroso florescimento dos jogos eletrônicos, em seus mais diversos gêneros e estilos, seria insuficiente atribuir apenas a essa conjunção jogos tecnologia a causa da popularização dos games.

Como propõe Joüet (JOÜET, 1997), citada por Miége (MIÈGE, 2009, p. 47), é preciso entender o papel dos jogos a partir de uma dupla mediação, onde a uma mediação técnica alinha-se outra mediação, a social, "porque os motivos, as formas de uso e o sentido atribuído à prática se alimentam no corpo social".

O que é capital é mostrar em que medida a esfera técnica também é feita de social, e em que medida as lógicas sociais da comunicação encontram objetos técnicos e se "sedimentam" entre si; em outros termos, trata-se de buscar como um (a esfera técnica) e outro (o social na sua complexidade) 
se articulam, e de abandonar o esquema de pensamento muito difundido, segundo o qual tudo provém de uma, ou de uma série de inovações técnicas principais: o resto, ou seja, o social, o cultural, o simbólico etc., delas depende e tem de a elas se adaptar. (MIÈGE, 2009, p. 18) 


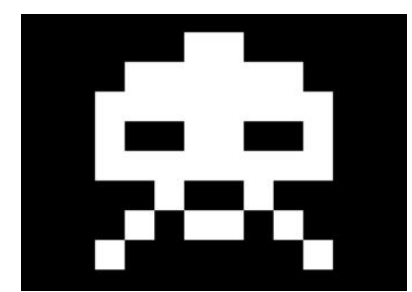

CAPÍTULO IV:

\section{A SOCIEDADE DA ESCOLHA}

\section{1. - A SOCIEDADE DA ESCOLHA}

$\mathrm{O}$ ato mais cultuado dentro das modernas sociedades ocidentalizadas talvez seja $\mathrm{o}$ ato de escolher. E seu culto, embora evidente em diversas situações cotidianas, está longe de ser desvendado com a eleição de uma única causa particular que o justifique. Pelo contrário, o ato de escolher traduz um complexo, um feixe de situações que remetem, em última instância, à própria condição geral vivenciada na contemporaneidade.

Não que o alcance e variedade das escolhas seja equânime entre os indivíduos que compõem a sociedade. A capacidade de escolher está intimamente atrelada ao poder. Quanto mais poder - econômico, político, social, cultural - mais capacidade de escolha.

Não por acaso, escolher é também sintoma do alto grau de competitividade experimentado no ambiente contemporâneo. Pois, num tempo onde a possibilidade e a capacidade de escolher torna-se uma das principais 
qualidades que distinguem os indivíduos dentro do campo social, escolher torna-se, em última instância, uma demonstração e um exercício de poder.

Nem que as escolhas possíveis sejam realmente escolhas em si. Muitas vezes, o que se toma como escolha são apenas ilusões, falsas escolhas - ou ainda, escolhas pífias - dentro de um sistema muito menos democrático do que o verbo "escolher", num primeiro instante, leva a acreditar.

Isso, entretanto, não impede 0 ato de escolher de tornar-se 0 polo agregador, a confluência de diversas aspirações modernas.

A primeira delas é que escolher é um dos principais sintomas de uma ideologia que opera, por diversos motivos, muito mais no plano da sedução do que no da coerção.

Lipovetsky, por exemplo, em seu livro "A Era do Vazio", reflete sobre esse fenômeno, que ele denomina processo de sedução. Para ele, a antiga disposição disciplinar não é mais conduzida pelas forças da Revolução, mas "pelas ondas radiantes da sedução".

Longe de estar circunscrita às relações de interação entre as pessoas, a sedução se tornou um processo geral com tendência a regrar o consumo, as organizações, a informação, a educação, os costumes. Toda a vida das sociedades contemporâneas passou a ser comandada por uma nova estratégia que destronou a primazia das relações de produção em favor de uma apoteose das relações de sedução (LIPOVETSKY, 2006, p. 1).

De fato, o ato de escolher traz consigo o inefável e irresistível sabor do empoderamento do indivíduo. A conexão entre sedução e escolha é forte e íntima. Oferecer escolhas é uma excelente forma de seduzir.

Neste sentido, a escolha, mais do que permanência, passa a ser a função dominante na construção diária da identidade. Isso vale quer para as escolhas oriundas de uma desregulamentação e erosão dos pilares disciplinadores da sociedade; quer pelo entrecruzamento que a multiplicidade de papéis vividos hoje em dia inevitavelmente traz; quer pela retórica que promove a era dos 
Direitos e que assegura aos indivíduos e minorias uma multiplicidade de possibilidades antes negadas; quer pelo ruído midiático que multiplica, conflita e propõe novas versões para o entendimento da vida; quer finalmente pela infinidade de escolhas promovidas por instâncias interessadas em lucrar e dominar, de alguma forma, com essa suposta autonomia.

É o que Bauman, em seu livro "Vida Líquida", interpreta como o nascimento do Homo Eligens - o homem que escolhe (BAUMAN, 2007, p. 48). Para ele, de fato, o único "cerne identitário" a sair são e e salvo dessa barafunda de mudanças contínuas é essa capacidade de incansavelmente escolher.

Portanto, não é de se estranhar que escolher, muitas vezes, passe a ser também a habilidade mais promissora dos indivíduos numa era onde tudo está sempre em jogo.

\section{2. - CONSUMISMO E ESCOLHA}

Um dos traços mais marcantes da contemporaneidade é o estímulo ininterrupto ao consumo de bens. Bens que obsolescem rapidamente e de forma programada, para que um novo ciclo de produtos, com novas propriedades e inovações, possam substituí-los.

Para autores como Bauman, essa é uma característica fundamental da lógica consumista. Esse ciclo não teria como objetivo a satisfação das necessidades dos consumidores (ao menos, não das necessidades tais como se conhecia na fase da Modernidade Sólida), mas sim a perpetuação de uma economia calcada no descarte e no excesso.

Aí reside para esse autor a característica-chave que distancia a era do consumismo do ato ancestral de consumir. $\mathrm{O}$ objetivo dos indivíduos inseridos no atual contexto passaria a ser muito menos possuir e acumular um 
patrimônio, mas muito mais satisfazer a uma demanda cada vez mais intensa de novos desejos (BAUMAN, 2008, p. 44) - sempre mutáveis, sempre transitórios, sempre guiados pelos ventos da novidade.

Em outras palavras, a transição do consumo para o consumismo torna-se tangível quando esses desejos e quereres transformam-se num ponto nevrálgico dentro do estilo de vida, e passam a desempenhar um papel cada vez mais central na personalidade, nas relações e nas escolhas dos indivíduos em sua vida cotidiana (BAUMAN, 2008, p. 39).

Dentro desta nova lógica, o consumo passaria a ser uma corrida em aberto, nunca plenamente satisfeita, incompleta na medida em que a obsolescência faz de qualquer aquisição apenas um gozo circunstancial, temporário. Nessa dinâmica, a meta dos consumidores seria a de se manterem atentos, razoavelmente equalizados dentro do fluxo de consumo, usufruindo sempre que possível do ápice dessa condição, que é a de comprar algo novo, de ponta.

Lipovetsky também percebe essa tendência de substituição contumaz, embora sua argumentação oriente-se posteriormente para outro caminho. Para ele, em seu livro "A Felicidade Paradoxal: Ensaio sobre a Sociedade do Hiperconsumo", esse comportamento é chamado de "febre da mudança perpétua".

Uma das características importantes dos bens de consumo em nossas sociedades é que eles mudam e que nós os trocamos indefinidamente, não cessando a oferta de inovar, de propor novos produtos e serviços. (LIPOVETSKY, 2007, p. 67)

Dentre as consequências dessa aceleração do ciclo de consumo, está o da dinamização exponencial dos produtos a serem ofertados. Incessantemente, o mercado é inundado por uma miríade de produtos que buscam brechas para se fazerem necessários nos aspectos mais incomuns da vida. A regra de ouro: excesso e desperdício (BAUMAN, 2008, p. 53). 
Dentro de tal aceleração, o próprio ciclo gerador das demandas é invertido. Não é mais a necessidade a mãe da invenção. Não se imaginam produtos para problemas a serem resolvidos. Pelo contrário, crescentemente imaginam-se produtos e depois se inventam necessidades para eles lembrando-se sempre de que, para cada produto que emerge vitorioso no campo de batalha do consumo, existem centenas de outros cujo destino é o oblívio.

Pois a guerra, também para os fabricantes, nunca está vencida, e o produto vitorioso em uma geração pode ser rapidamente superado num novo round, fazendo com que empresas que eram verdadeiros impérios se vejam, pouco tempo depois, graças a uma escolha infeliz nos produtos que oferta, falidas ou compradas por rivais.

Caso emblemático é o da Nokia, empresa que em poucos anos despencou do estrelato para a falência, até ser adquirida pela Microsoft. Nesse sentido, as palavras de Debord em seu aforismo 66 soam proféticas:

Cada mercadoria específica luta por si mesma, não pode reconhecer as outras, pretende impor-se em toda parte como se fosse a única. 0 espetáculo é então o canto épico desse confronto, que nenhuma queda de Ilion pode concluir (...) (DEBORD, 2007, p. 44).

É dentro desse contexto, que combina instabilidade e velocidade, que emerge o Homo Eligens. O termo é preciso em captar o instante fundamental do processo de consumo moderno - o ato de escolher.

Pois a qualidade preponderante do indivíduo, diante de uma ampliação gigantesca da oferta, de um ciclo cada vez mais dinâmico de substituição/obsolescência, diante de uma intersecção cada vez maior entre consumo e identidade, é a de exercitar seguidamente a arte da escolha - a mola-mestra desse processo.

Escolher tornou-se, de algo muitas vezes banal, numa qualidade fundamental dos viventes. E se o mercado ampliou dramaticamente a 
mercantilização de bens, atingindo os mais ínfimos aspectos da vida, é em todos os pequenos detalhes da existência que o exercício da escolha passa a se fazer presente.

Descobrem-se gostos e preferências em situações que, para nossos avós, seriam impensáveis. Pequenos detalhes passam a ser o palco de expressão da individualidade, do estilo, do modo de ser.

Vestuário, adereços, alimentos, filmes, desenhos animados, temperos, revistas, programas de TV, aplicativos para celulares, automóveis, esmaltes, marcas de cerveja, tipos de guardanapo, produtos de limpeza, gêneros musicais, vive-se uma vida inteira em escolha, compondo e recompondo esse sempre inacabado vitral, na cada vez mais abrangente moldura da individualidade e da pertença.

Entretanto, se existe um dinamismo sem precedentes na cadeia de consumo, os consumidores também não podem ser pensados como indivíduos pertencentes aos primórdios da era da propaganda. É razoável pensar que o consumidor de hoje, turbo-consumidor, ou ainda hiperconsumidor (ambos termos cunhados por Lipovetsky), é ele um ser também altamente treinado dentro do jogo do consumo.

[...] os comportamentos do hiperconsumidor deitam a perder a temática dos plenos poderes do marketing e da publicidade. Pois jamais os consumidores se mostraram tão desconfiados, voláteis, infiéis às marcas. O gosto generalizado pelas novidades, a hiperescolha, a fragmentação das modas, a saturação das necessidades primárias, tudo isso desenvolveu o zapping, a mobilidade, os amores e desamores em matéria de marcas. Mesmo as marcas mais cultuadas são vítimas de desinteresse, de rejeições por vezes rápidas, a despeito de orçamentos consideráveis destinados à comunicação. A época das megamarcas mundiais é também a de sua volatilidade ligada à instabilidade crescente do turboconsumidor (LIPOVETSKY, 2007, p. 183). 
É a esse consumidor fugidio, temperamental, veterano de muitas "campanhas e liquidações" que a indústria do consumo, guiada pelas agências de publicidade, luta para fisgar.

Fisgar porque, como um pescador, não é possível ter plena certeza de que a pescaria terminará em abundância. O atual jogo do consumo implica na aceitação de algo ainda muito difícil para a indústria - a aceitação de um consumidor que se porta de maneira bastante ativa diante desse processo. Um consumidor suscetível, uma "criança mimada e cheia de vontades", que só pode ser atraída pelo anzol da sedução.

\section{3. - CONSUMISMO E DIVERSÃO (FUN)}

E como opera essa sedução? Obviamente, ela cativa pelo princípio do prazer, pela diversão.

Aqui, o sentido atribuído à diversão (fun) é um sentido amplo. Esse princípio atua no sentido de que a experiência de compra (escolha) seja sempre algo excitante, tocante, que comova, que gere identificação, satisfação, surpresa, contentamento, diversão.

Como resultado final, a experiência em si deve ser suficientemente prazerosa para gerar não apenas uma compra, mas, idealmente, também engajamento e uma difusa sensação de gratificação no consumidor.

Não à toa, a grande maioria dos anúncios mostra frequentemente pessoas sorrindo enquanto seguram o produto da vez em suas mãos. Afinal, o sorriso é a prova de que aquele produto traz satisfação, conforto, contentamento.

Outra faceta do "fun" é a novidade. Afinal, quem não acha divertido conhecer coisas novas? 
Se é verdade que o laço do consumo com a novidade é agora estrutural, suas relações com o prazer não o são menos, uma vez que, como escrevia Freud, "a novidade constitui sempre a condição do gozo". Não é precisamente esse poder de novidade que constitui uma das grandes molas atrativas do consumo? O que é que seduz, na compra de produtos não correntes, a não ser, ao menos em parte, a emoção nova, por mínima que seja, que acompanha a aquisição de uma coisa? (LIPOVETSKY, 2007, p. 67)

Entretanto, fun não significa apenas uma situação nova ou divertida. Ela transborda tanto para situações anedóticas, com uso acentuado do humor para chamar a atenção sobre as pretensas qualidades do produto, quanto também para experiências de consumo que envolvam outras emoções, como o medo e a tensão.

Assistir a um trailer de um filme de terror pode ser divertido, fun, embora a experiência provoque medo. Fun, em última escala, significa algo que, por quaisquer qualidades catárticas que consiga provocar, entretém, chama a atenção, distingue o produto de seus similares e gera uma experiência divertida.

O efeito inverso disso é que, na medida em que esse atributo se disseminou por todo o universo de consumo, a morte de um produto, muitas vezes um excelente produto, é praticamente decretada na medida em que ele não se mostre palatável, agradável, chamativo ao primeiro olhar.

O grande público, moldado e acostumado às jogadas de efeito, reage mal a produtos que não venham embalados dessa forma, que não provoquem imediatamente excitação, diversão.

Uma das áreas que se rendeu a esse processo, por exemplo, foi o cinema, com a aceleração dramática dos enredos e dos planos-sequência, para satisfazer a um consumidor que se entedia se não for rapidamente fisgado. A discrepância de ritmo entre filmes mainstream da década de sessenta e os atuais é um bom indicativo disso. 
No mesmo grau, crescem vertiginosamente os departamentos de design e de usabilidade dos produtos nas empresas. A experiência deve ser sensória, encantar para muito além da funcionalidade prometida.

Uma cafeteira, por exemplo, deve transpirar beleza futurista, ou então remeter a algo vintage, ou ainda apelar para plásticos e cores berrantes, ou servir o conteúdo de forma inusitada. Tomar café deve transformar-se, de uma experiência banal, numa micro-apoteose, num momento fun.

\section{4. - CONSUMISMO E FANTASIA}

Entretanto, como transformar em agradável e divertida a experiência com produtos que, em realidade, são desesperadamente insossos? Ou produtos que atendem a aspectos pouco glamourosos da vida? Ou ainda, produtos altamente técnicos, que se perdem em especificidades? A saída é, literalmente, lançar mão do segundo princípio proposto: fantasiar, imaginar.

Em seu nível mais comedido, as peças de marketing apresentam imagens e descrevem qualidades que, de fato, estão presentes no produto anunciado, ainda que num grau muito menor. Exemplos disso são as imagens que aumentam o tamanho dos produtos, ou que os deixam com uma aparência muito mais chamativa do que, na realidade, são.

Um segundo nível já se vale de elementos surreais para promover as pretensas qualidades do produto. Basta acompanhar alguns filmes publicitários na TV para encontrar caldos de legumes que fazem as pessoas levitarem de felicidade, ou pastas dentais que varrem as cáries da boca num grande maremoto, ou pílulas que magicamente tiram a dor de cabeça na hora, ou produtos de limpeza que deixam o chão brilhando de modo faiscante, ou ainda automóveis que enfrentam inviáveis estradas de terra, sobem por montanhas íngremes e atravessam vaus traiçoeiros com firmeza e decisão. 
Num terceiro nível, não é mais necessário haver conexão com o produto, mas sim com o sentimento que se quer instilar no consumidor. $O$ ar fantasioso permanece. Podem ser os cavalos do mundo de Marlboro, ou uma balada alucinante de Smirnoff, ou uma praia paradisíaca de Sundown, ou um glorioso piquenique em família com Becel. Ou pode ser o mais puro nonsense, como a clássica propaganda da D.D.Drim, onde os insetos dão uma festa da pesada, até chegar a dedetização.

Em todos esses níveis, há constantemente um apelo a processos imaginativos para suplementar, reforçar, fantasiar e enquadrar os produtos dentro do mundo fun que orienta o consumo. A fantasia, neste caso, trabalha como a liga através da qual, dentro de um enquadramento fun, se propõem novos significados aos produtos.

Naturalmente, um dos efeitos colaterais desse processo é que o uso intensivo da fantasia servindo aos interesses comerciais das empresas repovoa os próprios limites do real. É como se pairasse uma nuvem midiática que povoa o cotidiano com uma névoa de fantasia. Vive-se, hoje em dia, num mundo tomado por poções mágicas e unguentos milagrosos, que curam e trazem a beleza não importa a idade, por veículos capazes de feitos inimagináveis, por produtos que realizam feitos incríveis, como purificar a água, adicionar um sabor irresistível a qualquer prato, amaciar roupas num piscar de olhos, emagrecer quilos de uma vida toda em apenas duas semanas, num nível de superstição e fantasia tão profícuo quanto o da Idade Média.

Finalmente, o princípio que direciona a adoção de um estilo fun, bem como da fantasia a serviço da publicidade é a exploração do sentimento de onipotência. É a sensação de poder, esse inebriante estado de espírito, que aguça o ego do consumidor no momento da escolha. 


\section{5. - CONSUMISMO E ONIPOTÊNCIA}

A maneira mais direta pela qual esse mecanismo funciona é através da sempre aclamada valorização do indivíduo. Uma frase-clichê que resume bem a intencionalidade disso é: "Você é muito especial para nós". Tome-se como exemplo o anúncio do cartão de crédito da CAIXA:

Você é especial. O seu cartão de crédito também precisa ser. (CAIXA, 2014)

Outras vezes, a mesma mensagem é transmitida de maneira um pouco mais sutil, mas com os mesmos propósitos, como no caso desta campanha institucional do McDonalds.

A nova campanha institucional do McDonald's, intitulada "Que bom que você veio", acaba de estrear e vai permear todas as ações de marketing da empresa ao longo do ano. (ADNEWS, 2014).

Outra maneira de exacerbar o sentimento de onipotência é hipervalorizar o ego e as sensações do consumidor. A Starbucks Coffee, por exemplo, trabalha esse tipo de sentimento até no item mais banal da sua linha, o próprio saco de papel que acompanha seus produtos:

Dá sabor aos meus sentidos,

Adoça minha disposição,

Aguça minha imaginação,

Nutre meus sonhos. ${ }^{5}$

Associações com profissões aventureiras e glamourosas também reforçam o sentimento de onipotência daqueles que o possuem. É assim que pessoas

\footnotetext{
${ }^{5}$ Material de propaganda Starbucks Coffee, coletado em loja da rede em 10/01/2014. No original: Flavors my senses/ Sweetens my disposition /Stirs my imaginations,/ Nourishes my dreams.
} 
que nunca puseram um pé numa cabine de comando usam óculos Ray-Ban Aviator.

Outra maneira de se trabalhar esse sentimento de onipotência é através de anúncios que mostram famosos em ambientes espetaculares ou situações idílicas, demonstrando sua preferência por esta ou aquela marca.

Se hoje são os famosos (e a fama) a demonstração máxima de potência dentro de uma sociedade devotada ao espetáculo, é de se esperar que sejam vistos como deuses modernos. E consumir o mesmo produto que um deus moderno consome, compartilhar do mesmo produto com ele, se traduz em circunstancial onipotência, ainda que restrita ao mundo íntimo e fantasioso do indivíduo, ou ao seu restrito universo de amigos e conhecidos.

De modo geral, o que se sugere com esse mecanismo é que o produto anunciado empresta qualidades tais que quem os utiliza se torna especial por ser possuidor de algum tipo de potência, ou ainda que o consumidor é desde sempre um ser particularmente especial, merecedor de distinção.

Não que isso signifique, reitera-se, que o consumidor seja um ser apassivado, pronto a ser envolvido pelas técnicas e truques publicitários. Há, aqui, um jogo, uma negociação, na qual o consumidor por vezes pode até ser envolvido, mas que na maioria das vezes também se deixa levar, quando e onde lhe for conveniente.

Nesta nova ordenação, consumir torna-se um dos principais aglutinadores da própria identidade, pois não apenas pelo consumo, mas também através do consumo os indivíduos se integram, se distinguem, mimetizam e interagem com os diferentes ambientes sociais que compõem seu dia a dia. Como se, aponta Canclini, consumir fosse a condição universal que a todos iguala e se transformasse, no século XXI, naquilo que foi a cidadania política no século anterior.

Homens e mulheres percebem que muitas das perguntas próprias dos cidadãos - a que lugar pertenço e que direitos isso me dá, como posso me 
informar, quem representa meus interesses - recebem sua resposta mais através do consumo privado de bens e dos meios de comunicação de massa do que pelas regras abstratas da democracia ou pela participação coletiva em espaços públicos (CANCLINI, 1999, p. 29).

A consequência é que se o consumo tornou-se hoje pedra angular da civilização atual, os princípios hedônicos que o sustentam são hoje também compartilhados pelos consumidores e disseminados o suficiente para tornaremse traços culturais relevantes.

O que aqui se advoga é que essas condições - exploração de uma eterna condição de diversão, uso intensivo de elementos de fantasia, invocação quase contínua de um sentimento de onipotência - tornaram-se não apenas uma característica dos apelos de compra, mas também foram absorvidas e enraizadas dentro do grosso do corpo social, a ponto de se tornarem traços culturais gerais, manifestados pelos indivíduos não apenas em situações de consumo, mas também em outras ocasiões e em outros campos onde se dá a vida cotidiana.

As pessoas pertencentes a esse corpo social são, em sua maioria, dilatadas devoradoras de fantasia; buscam, muitas vezes, como um ideal a ser alcançado, a condição de euforia, contentamento e felicidade; e manifestam em diversas situações cotidianas traços de um comportamento onipotente. Nesse sentido, buscam e propagam valores que coadunam diretamente com aquilo que os jogos, tradicionalmente, também oferecem.

\section{6. - IDENTIDADE E ESCOLHA}

A questão da identidade - a que lugar e tradições se pertence, onde se encaixar dentro do sistema produtivo, de qual classe social e de qual(is) cultura(s) se participa, enfim, quem se é no mundo - é hoje uma das questões 
primordiais no campo da teoria social, justamente por ser palco de profundos redimensionamentos dentro da vida cotidiana.

Afinal, se antes as identidades tradicionais davam conta da existência de modo razoável, estabelecendo claramente a fronteira entre os integrados e os estigmatizados, entre locais e estrangeiros, fornecendo uma linha de conduta para as diversas interações sociais, enfim, emprestando, ainda que de maneira muitas vezes draconiana, solidez e estabilidade ao viver, atualmente, pela soma de diversos fatores, essa linha se desvanece, torna-se móvel, ora reemerge, ora se desfaz. Isso se traduz na seguinte questão: em que medida a racional que ordenava o mundo foi deslocada, a ponto da identidade deixar de ser algo tácito e tornar-se assunto tão relevante?

As possíveis explicações para o estremecimento das estruturas que moldavam os contornos da identidade espraiam-se transversalmente, encontrando razões nos campos cultural, econômico, social e político, e ainda provocam muita controvérsia no meio acadêmico, uma vez que a extensão das mudanças, o grau de ruptura - e mesmo se há ruptura - permanecem em debate. Abaixo, segue uma lista breve de alguns dos fatores que são objeto dessa ampla discussão:

a) No campo econômico, por exemplo, desde a década de oitenta assistese a uma desregulamentação cada vez maior das fronteiras dos Estados-Nações em benefício do livre-comércio, bem como uma globalização financeira (zonas de livre comércio, redução de barreiras tarifárias), o que torna, em última instância, todos os países muito mais dependentes das variações econômicas uns dos outros.

Isso trouxe consigo um nível inédito de insegurança aos trabalhadores do mundo todo. Reengenharias, redução de postos, precarização de contratos, realocação de fábricas entre diferentes países, intermitências e sazonalidade nos postos de trabalho, fim de reservas de mercado, tudo isso contribuiu decisivamente para a erosão do trabalho como um dos pilares onde se assentavam as identidades no passado. 
Nesse sentido, aliás, estão inclusas não apenas as identidades individuais, mas a própria condição identitária do Estado-Nação, calcada tradicionalmente tanto no emprego industrial de massa quanto na conscrição em massa, em caso de guerra. É o que aponta Bauman, em seu livro "A Sociedade Individualizada", ao comentar essa reorientação da natureza do Estado e suas implicações na maneira pela qual se apresenta o trabalho hoje:

\footnotetext{
Sejamos claros quanto a isso: as pessoas tradicionalmente chamadas de "desempregadas" não são mais um "exército de reserva do trabalho", assim como um homem adulto na Holanda e na Inglaterra já não é mais um reservista do Exército prestes a ser chamado para se unir às tropas em caso de necessidade militar. Estaremos nos enganando se esperarmos que a indústria volte a chamar as pessoas que ela tornou redundantes. Tal eventualidade iria contra tudo que é relevante para a prosperidade econômica atual: os princípios de flexibilidade, concorrência e produtividade, medidos pelos custos laborais decrescentes. (BAUMAN, 2009, p. 99)
}

b) Também atrelado às novas configurações econômicas, o desencaixe da tradição também se dá na própria constituição étnica-cultural sustentada pelo Estado-Nação, uma vez que a globalização econômica também acentuou dramaticamente o fluxo migratório de milhões de pessoas por todo o mundo, em busca de melhores oportunidades de vida, com impactos evidentes no campo social e cultural.

Exemplos contemporâneos desse impacto estão na suposta "islamização da Europa", ou ainda na "herança colonial", composta por milhões de imigrantes das ex-colônias que buscam nas antigas metrópoles uma condição de vida melhor; ou mesmo na "latinização dos EUA".

Esses exemplos colocam diretamente em xeque o conceito das identidades nacionais como um "todo puro", quer étnica, quer culturalmente. Ou, nas palavras de Hall, em seu livro "A Identidade Cultural na PósModernidade", "esta formação de enclaves étnicos minoritários no interior dos estados-nação do Ocidente levou a uma 'pluralização' de culturas nacionais e de identidades nacionais" (HALL, 2004, p. 83). 
O aguçamento das diferenças provocado pelos crescentes fluxos migratórios também desencadeia diversas reações.

A primeira é que expõe, contesta e corrói a prática discursiva através da qual, pelo exercício de uma dada identidade culturalmente hegemônica, se ocultavam as relações de poder dentro das fronteiras do Estado-Nação.

A segunda é que provoca, como uma reação a esse abalo, uma intensificação das tradições e particularidades locais, num explicitamento da diferença, antes mantido sob o véu da grande "identidade nacional".

E a terceira é o crescimento cada vez maior de uma nova língua franca, que media essas diferenças, que é o que Ortiz denomina como "cultura internacional popular" (GIOIELLI, 2005).

c) Um outro fator que tem contribuído decisivamente para esse abalo do sistema cultural e identitário tem sido o crescimento exponencial das TICs e seu enraizamento profundo no tecido social. Isso abrange tanto os meios de comunicação massivos quanto os novos meios: digitais, individualizados e horizontalizados.

Vive-se hoje numa civilização midiática, capaz de sustentar uma esfera simbólica de grande intensidade e autonomia. Nesse campo simbólico, sustentado pela tecnologia, alimentado tanto por governos, quanto pelas grandes corporações, quanto por milhões de indivíduos, circulam ideologias, valores, visões de mundo, representações idealizadas. Aproxima-se o que é distante, do mesmo modo como se ampliam e contrastam com muito mais vigor as dissonâncias.

E se a ampliação da oferta não significa que os indivíduos necessariamente mudem seus padrões comportamentais, ao menos permite uma nova janela de visibilidade a todos os tipos de minorias, tornando públicas expressões de identidade até então banidas e mantidas invisíveis pela força da tradição. 
d) Além disso, essa estrutura midiática também abriga e vive em comunhão íntima com o consumo, outro fator de forte abalo às identidades tradicionais. Afinal,o consumo, pela própria necessidade da inovação perpétua, é um elemento propositor do novo - ainda que sob certas condições, ainda que, na maioria das vezes, em consonância com certos valores hegemônicos.

É assim que novas possibilidades identitárias são oferecidas pelo consumo com uma aura de fantasia e novidade. São as chamadas "identidades de prateleira": suprem as carências, propõem novos parâmetros de comportamento, sugerem situações inusitadas, fetichizam objetos/situações, ora corroendo, ora reforçando os padrões hegemônicos tradicionais, numa dubiedade cujo norte é sempre a compra.

Além disso, num corte maior, a globalização do consumo também fratura a própria condição de unidade do corpo social nos países, especialmente os países em desenvolvimento, como aponta Renato Ortiz no livro "Mundialização e Cultura". Pois, se por um lado, o fluxo global de produtos inundou os mercados nacionais com produtos estrangeiros, enriquecendo a gama de escolhas possíveis para os consumidores e integrando-os numa cultura global de consumo, por outro lado, esse mesmo fluxo compete com as bases culturais tradicionais.

A modernidade-mundo nos países 'periféricos' é perversa, selvagem, mas real. A globalização provoca um desenraizamento dos segmentos econômicos e culturais das sociedades nacionais, integrando-os a uma totalidade que os distancia dos grupos mais pobres, marginais ao mercado de trabalho e consumo (...) A mundialidade da cultura penetra os pedaços heterogêneos dos países 'subdesenvolvidos', separando-os de suas raízes nacionais (ORTIZ, 2003, p. 179).

e) Ademais, insuflada pelo consumo globalizado, pelas diferentes indústrias culturais, pela expansão generalizada das TICs e pela circulação ampliada de bens simbólicos, expande-se há décadas uma bem assentada cultura pop global. 
Afirmar a existência de uma memória internacional-popular é reconhecer que no interior da sociedade de consumo são forjadas referências culturais mundializadas. Os personagens, imagens, situações, veiculadas pela publicidade, histórias em quadrinhos, televisão, cinema constituem-se em substratos dessa memória. Nela se inscrevem as lembranças de todos. As estrelas de cinema, Greta Garbo, Marylin Monroe ou Brigitte Bardot, cultuadas nas cinematecas, pôsteres e anúncios, fazem parte de um imaginário coletivo mundial. (ORTIZ, 2003, p. 126)

Ou seja, a cultura global - com suas referências imagéticas, seus comportamentos propostos, suas frases e modos de se expressar - contribui para a relativização dos papéis antes exercidos de forma inconteste dentro de uma determinada realidade cultural.

f) Outro ponto relevante de erosão dos antigos parâmetros hegemônicos e proliferação da diferença está ligado a um contexto histórico de luta pela igualdade de direitos civis, tendência que ganha um largo impulso após os horrores e violações da Segunda Guerra Mundial.

Diante de tantos episódios de barbárie, emerge, como uma reação, a Declaração Universal dos Direitos Humanos, promulgada em 1948 pela ONU, cuja importância está não apenas na universalização dos direitos a todos os seres humanos, mas também na criação de um documento de caráter supranacional (BOBBIO, 2004), roubando dos Estados o poder de legislação e regulação destes direitos.

De fato, nas décadas seguintes, amparados por esse princípio de igualdade, vários são os movimentos que buscam uma equiparação. No plano social, nos Estados Unidos, nas décadas de cinquenta e sessenta, articula-se o movimento pelos direitos civis dos negros. No mundo como um todo, ganha força o movimento pelos direitos da mulheres (feminismo), bem como toda uma série de contestações abrigadas dentro da chamada Contracultura. Nas décadas de setenta e oitenta, emerge o movimento pelos direitos dos homossexuais, revelando fraturas e desigualdades antes maquiadas por uma 
estrutura tradicional coercitiva. Mais recentemente, o cuidado com o meioambiente e com os animais amplia ainda mais o debate e o campo dos direitos.

Num balanço, ao longo dos últimos sessenta anos, é inegável que essas revoluções sociais culminaram numa série de distensões nos campos social e cultural (liberdade de culto, direito ao divórcio, adoção de crianças por homossexuais, etc..), ampliando e pluralizando dramaticamente possibilidades identitárias antes desamparadas social, cultural e, principalmente, legalmente.

Indicativo disso é a tendência jurídica observada nas últimas décadas, apontada por Bobbio, em seu livro "A Era dos Direitos", chamada por ele de "especialização", que é não apenas o reconhecimento dos direitos básicos universais (igualdade), mas também o reconhecimento de que, embora iguais, os seres humanos gozam de condições essencialmente diferentes e devem ser respeitados também em suas particularidades.

Essa especificação ocorreu com relação seja ao gênero, seja às várias fases da vida, seja à diferença entre estado normal e estados excepcionais na existência humana. Com relação ao gênero, foram cada vez mais reconhecidas as diferenças específicas entre a mulher e o homem. Com relação às diferentes fases da vida, foram-se progressivamente diferenciando os direitos da infância e da velhice, por um lado, e os do homem adulto, por outro. Com relação aos estados normais e excepcionais, fez-se valer a exigência de reconhecer direitos especiais aos doentes, aos deficientes, aos doentes mentais, etc. (BOBBIO, 2004, p. 59)

g) Finalmente, dentro de um contexto histórico-filosófico, há que se pensar no próprio redimensionamento experimentado hoje em relação às utopias sustentadas pela Modernidade, em seu projeto de emancipação do Homem pelo uso da Razão.

O estremecimento da noção de progresso; a morte da Verdade universal e abstrata e a consciência de que ela se espraia por muitas verdades diferentes, negando um princípio ordenador; a fadiga dos aparatos tradicionais (trabalho, escola, ciência) diante das demandas cotidianas; o horror diante de Hiroshima e 
de Auschwitz; a perplexidade diante da degradação da natureza; enfim, o próprio esgotamento diante dos "grandes relatos", tudo isso, nas palavras até dos mais ferrenhos defensores da Modernidade, como Rouanet, exprime o cansaço que o homem contemporâneo experimenta diante da Modernidade (ROUANET, 2008, p. 268).

Exaustão essa que também se espraia pelas formulações tradicionais das identidades, na medida em que estas também são a expressão, dentro do plano cotidiano, da racional moderna. Como aponta enfaticamente Lipovetsky, em seu livro "A Era do Vazio":

Quem foi poupado por essa correnteza da maré? Aqui, como em qualquer lugar, o deserto cresce: o saber, o poder, o trabalho, o exército, a família, a Igreja, os partidos, etc. já pararam de funcionar globalmente como princípios absolutos e intangíveis; em graus diferentes, ninguém mais acredita neles, ninguém investe neles o que quer que seja. (LIPOVETSKY, 2006, p. 18)

Enfim, muitos são os fatores que podem ser elencados para tentar dar conta das mudanças experimentadas pelas sociedades modernas, que encontram no tema da identidade um dos palcos mais visíveis desses embates.

Claro, difícil é precisar em que medida estas mudanças são os sintomas de uma ruptura, ou uma mutação do que havia antes, ou apenas um enfado com um projeto moderno ainda em aberto, ainda em construção.

O que parece evidente é que, qualquer que seja a dimensão dessa transformação, ela trouxe consigo uma expressiva desregulamentação dos papéis identitários tradicionais. É o que Hall aponta quando comenta sobre o processo de construção da identidade dentro desse novo contexto:

Quanto mais a vida social se torna mediada pelo mercado global de estilos, lugares e imagens, pelas viagens internacionais, pelas imagens da mídia e pelos sistemas de comunicação globalmente interligados, mais as identidades se tornam desvinculadas - desalojadas - de tempos, lugares, 
histórias e tradições específicas e parecem "flutuar livremente" (HALL, 2004, p. 75).

Essa mesma sensação de "flutuar livremente" também é percebida por Bauman, em seu livro "Identidade", quando comenta o enfraquecimento das estruturas que sustentavam a existência e compara a construção da identidade no contexto atual como um empreendimento construído em pleno voo.

Não mais monitorados ou protegidos, cobertos e revigorados por instituições em busca de monopólio - expostos, em vez disso, ao livre jogo de forças concorrentes -, quaisquer hierarquias ou graus de identidades, e particularmente os sólidos e duráveis, não são nem procurados nem fáceis de construir. As principais razões de as identidades serem estritamente definidas e desprovidas de ambiguidade (tão bem definidas e inequívocas quanto a soberania territorial do Estado), e de manterem o mesmo formato reconhecível ao longo do tempo, desapareceram ou perderam muito do poder constrangedor que um dia tiveram. As identidades ganharam livre curso, e agora cabe a cada indivíduo, homem ou mulher, capturá-la em pleno voo, usando os seus próprios recursos e ferramentas (BAUMAN, 2005, p. 35).

Em outras palavras, se antes a identidade de um ser humano era, em grande parte, moldada por condições dadas, hoje, pela erosão das instâncias reguladoras e pela ação de uma série de forças transformadoras, a construção da identidade impõe-se como uma tarefa proeminentemente de garimpagem individual.

É claro que as diferenças não foram suprimidas. Questões relativas ao gênero sexual, à classe social, ao nível educacional/cultural, ao background familiar ainda exercem papel decisivo na composição daquilo que uma pessoa é, e de como o mundo a enxerga. Entretanto, os diferentes deslocamentos ocorridos no campo da cultura e da sociedade aumentaram dramaticamente as possibilidades de expressão identitária, criando um contra-balanço significativo na fórmula final dessa equação. 
E é justamente neste ponto que a questão da identidade cruza com a questão da escolha. Pois se há um aumento significativo das possibilidades identitárias e se esse processo é cada vez mais transferido para a consciência individual, a síntese dessa dinâmica condensa-se no ato de escolher, com a liberdade e a ansiedade inerentes à tomada de cada decisão.

Há uma frase de Jencks (JENCKS, 1989), citado por Kumar (KUMAR, 1997), que é lapidar nesse sentido e que consegue capturar não apenas a relevância do ato de escolher, como também os benefícios e os aspectos desafiadores inerentes a essa condição.

A era pós-moderna é um tempo de opção incessante.É uma era em que nenhuma ortodoxia pode ser adotada sem constrangimento e ironia, porque todas as tradições aparentemente têm alguma validade. [...] O pluralismo, 0 'ismo' de nossa época é, ao mesmo tempo, o grande problema e a grande oportunidade: quando Todo Homem se torna cosmopolita e, Toda Mulher, um Indivíduo Liberado, a confusão e a ansiedade passam a ser estados dominantes de espírito [...]. Este é o preço que pagamos pela era pósmoderna, tão pesada à sua maneira como a monotonia, o dogmatismo e a pobreza da época moderna. (KUMAR, 1997, p. 142)

Ademais, há que se considerar não apenas a imensa gama de escolhas que compõem a expressão da identidade contemporânea, mas também o fato de que $o$ ato de escolher é atividade exercida continuamente.

Isso porque a identidade não é um edifício herdado, que uma vez construído goza de uma quase-permanente solidez. Pelo contrário, a tarefa de ser alguém se torna, nesse cenário, cada vez mais um projeto eternamente inacabado, sujeito a reinterpretações, fluído, mutante, alimentado por fontes múltiplas e assumindo formas também múltiplas (KUMAR, 1997).

E é por essa razão que escolher torna-se o ato primordial, o ato criador dessa nova conjuntura. Um ato que se desdobra cotidianamente, nos múltiplos papéis exercidos, nos momentos de consonância entre esses papéis, mas também nos momentos em que eles conflitam, obrigando a uma prevalência 
(momentânea) de um deles. Escolher tornou-se, em grande medida, o modo pelo qual se opera o "ser e estar" identitário no mundo de hoje.

E quais os parâmetros através dos quais se fundamenta a escolha identitária nos dias de hoje? Embora não se reduzam a isso, destacam-se, para os fins deste trabalho, os mesmos três aspectos estudados anteriormente quando detalhada a relação entre escolha e consumo: a questão da diversão (fun), a questão da fantasia e a questão da onipotência.

Ao enfocar novamente estes três pontos, procura-se demonstrar que esses parâmetros, encontrados facilmente no jogar, são profundamente relevantes dentro do jogo social não apenas por sua relação íntima com o consumo, como já visto, mas também por conta de outros motivos atrelados à problemática da identidade.

\section{7. - IDENTIDADE E DIVERSÃO}

O primeiro aspecto que se pretende discutir é a questão da diversão (fun), que, em relação à questão da identidade, desempenha uma dupla função: a) é utilizado como estratégia de crítica a toda e qualquer estrutura moderna; b) é utilizado como uma estratégia de construção de sentidos, na medida em que se torna, cada vez mais, a "medida universal" pela qual se mensuram as opções identitárias.

Em relação à primeira função da diversão dentro desse contexto, uma célebre frase de Kant já dizia que "o riso é uma reação à súbita transformação de uma grande expectativa em nada".

Essa frase poderia muito bem ser empregada para definir a reação diante do desmantelamento da cadeia de valores que durante um largo tempo gerou grandes expectativas dentro do projeto Moderno. 
É assim que a ironia, o desdém, a mofa e a indiferença - a face sombria do humor, o"fun" em sua expressão ferina - passam a ser as armas com as quais se combate qualquer alusão aos deveres modernos que ainda teimam em resistir.

Na escola, do nível universitário à educação primária, por exemplo, são recorrentes as queixas dos professores diante da mais pura indiferença dos alunos, ou da ironia que não se deixa abater mesmo diante de punições.

É como se, dentro da nova lógica onde a experiência do mundo se divide em coisas "fun" (e seu oposto "boring"), as antigas estruturas, laços e valores não encontrassem ressonância ou aderência, como se não fossem dignos de serem sequer considerados ou ao menos combatidos.

A eles cabe a indiferença - manifestada através da linguagem corrente da diversão - que é o humor relaxado, o risonho e irônico "não estar nem aí". Vivese, dentro desta nova conjuntura, sob a égide do "whatever".

É o que aponta, por exemplo, a análise proposta por Lipovetsky em seu livro "A Era do Vazio". "A descrença pós-moderna, o neoniilismo que toma corpo não é nem ateu nem mortífero: é a partir de agora humorístico" (LIPOVETSKY, 2006, p. 112).

Para ele, embora o cômico seja um aspecto sempre presente em todas as sociedades ao longo dos tempos, apenas a sociedade pós-moderna pode ser classificada como humorística, na medida em que ela tende, pela sua própria estratégia de desconstrução, a dissolver a oposição entre o sério e o não-sério.

Enxerga-se, ainda segundo a leitura de Lipovetsky, essa peculiaridade pós-moderna ao submeter o cômico a uma análise histórica. Na Idade Média, o cômico se expressaria principalmente através das festas populares e carnavalescas. Nelas, o cômico encontrava saída através das inversões, do grotesco, das piadas, blasfêmias e injúrias. 
Já na idade Clássica, entretanto, o grotesco medieval é enquadrado dentro de um processo de decomposição do riso, no qual são purgados os elementos mais obscenos e escatológicos. O cômico então se torna crítico, se expressa pela comédia clássica, na sátira, na fábula, na caricatura, no teatro de revista, no vaudeville. Oculta, a racional que ordena esse tipo de expressão baseia-se numa estrita disciplina, na domesticação das manifestações do corpo.

\begin{abstract}
Nas sociedades disciplinares, o riso, com seus excessos e exuberâncias, encontra-se inexoravelmente desvalorizado; ele, que não exige exatamente nenhum tipo de aprendizado: no século XVIII, o riso alegre se torna um comportamento desprezado e vil que, até o século XIX, foi considerado vulgar, inconveniente e até mesmo perigoso e tolo, por encorajar a superficialidade e, pior, a obscenidade. À mecanização do corpo disciplinado responde a espiritualização-interiorização do cômico: a mesma economia funcional visando impedir os gastos desordenados, o mesmo processo celular produzindo o indivíduo moderno (LIPOVETSKY, 2006, p. 115).
\end{abstract}

Em contraposição, na era atual, quer através da moda, da publicidade, dos desenhos animados ou dos quadrinhos, o tom geral que impera é o lúdico, um cômico adolescente, que - ao contrário do humor corrosivo da era anterior - tem como intenção apenas "prodigalizar uma atmosfera eufórica de bomhumor e felicidade sem avesso" (LIPOVETSKY, 2006, p. 115).

É esse sentido humorístico, que tem a diversão como critério maior de julgamento, que se transforma num dos maiores norteadores na busca por padrões identitários no quadro contemporâneo. Sintoma de uma sociedade hedonista, sintoma de uma sociedade que internalizou a lógica do espetáculo, assiste-se hoje a uma busca frenética por padrões que traduzam a existência e a identidade como algo divertido, estratégia, como pontua Bauman, de carpe diem, como reação a um mundo esvaziado de valores que finge ser duradouro (BAUMAN, 2005, p. 59).

Naturalmente, isso não apaga as restrições de ordem econômica. Indivíduos pertencentes às esferas mais endinheiradas experimentam um grau muito maior de escolha, de mobilidade e de momentos divertidos, ao passo que 
os mais desprovidos convivem com toda uma sorte de restrições que reduzem e limitam dramaticamente suas possibilidades eletivas.

Ainda assim, isso não significa que essa característica não permeie todos os extratos sociais. O sucesso do "Funk Ostentação", que trata de baladas épicas e festas de arromba, de joias, dinheiro, carrões e poder; a "Teologia da Prosperidade", pilar que orienta boa parte da sedução proposta por várias igrejas pentecostais; ou ainda o "estilo Periguete", com sua estética sexualizada e ostensiva, bricolagem de uma estética proposta pelas celebridades e revistas de fofocas, são expressões de escolha, e de escolha por um ideal hedonista, escolha por diversão, que supera qualquer orientação por classes sociais.

De fato, a lógica da diversão espraia-se por todo o corpo social. Exemplo rico disso é o uso das mídias sociais, como Facebook e Google+, que hoje são condição de cidadania e pertencimento quase universal. Não importa a condição social, o padrão de comportamento é razoavelmente similar. Alguns posts de humor, outros manifestando opiniões polêmicas, mais alguns posts sobre peculiaridades familiares, outros ainda sobre gostos musicais e, claro, muitos posts sobre os mais diversos aspectos da personalidade do indíviduo, 0 que inclui selfies e descrições dos estados de humor no momento. Tudo isso permeado por endossos aos posts dos outros, em alianças mútuas de reconhecimento. A meta: através da escolha cuidadosa, gerar um apanhado, um corpo de expressões que, ao fim e ao cabo, sancionem essa pessoa como divertida, interessante, cool -fiel reprodução microcósmica da dinâmica que hoje se manifesta no macrocosmo.

Em resumo, o que se quer evidenciar é que ser divertido, fun, tornou-se uma das características mais valorizadas quando se trata de lapidar a personalidade dentro da contemporaneidade.

Do mesmo modo, é esse um dos principais critérios que os indivíduos utilizam quando julgam e valoram as expressões identitárias dos outros, ou mesmo de quaisquer aparatos e instituições que compõem o mundo, como a 
escola, as diferentes religiões, o trabalho, a política, as amizades, a família e os relacionamentos amorosos.

Na conjuntura atual, ser divertido não é mais um traço ou uma peculiaridade. Tornou-se questão de sobrevivência, tanto para os indivíduos, quanto para as diferentes instituições sociais.

\section{8. - IDENTIDADE E FANTASIA}

Se uma das consequências da fratura do mundo é uma maior autonomia nas escolhas de vida, e se essa busca é guiada muito mais pelos prazeres do que pelos deveres, não é surpresa que o uso da fantasia tenha se tornado tão intensivo e tão preponderante dentro do cenário atual.

Afinal, apenas a fantasia, com sua onírica capacidade de aglutinação, consegue emprestar consistência ao que antes seria tomado como inconsistente, absurdo, não-coerente. É seu uso intensivo que apazigua posturas e princípios que antes seriam impossíveis de serem conciliados num único indivíduo. É ela o "novo-velho" élan que permite moldar os cacos e fragmentos da era das identidades coesas e reagrupá-los dentro desta nova perspectiva caleidoscópica dos dias atuais.

E utiliza-se o termo "novo-velho" porque, de fato, a fantasia é e sempre foi algo fundamental dentro da experiência simbólica dos Homens. Foi essa capacidade imaginativa, por exemplo, que desde a aurora dos tempos ajudou os homens a sustentarem o sentimento de pertencimento a algo: a um clã, a uma nação, a uma comunidade de fiéis, a uma estrutura política. E foi ela que, durante os últimos duzentos anos, sustentou o grande encantamento conjurado pela Modernidade, escorado em boa parte na fantasia do Estado-Nação, com sua respectiva cultura nacional. 
Não por acaso, Enoch Powell (POWELL, 1969), citado por Hall, é taxativo quando pondera que "a vida das nações, da mesma forma que a dos homens, é vivida, em grande parte, na imaginação" (HALL, 2004, p. 51).

É o que também aponta Appadurai, ao discorrer sobre o papel da imaginação dentro da conjuntura atual:

Imagem, imaginado, imaginário: são todos termos que nos orientam para algo de fundamental e de novo nos processos culturais globais: a imaginação como prática social. Já não é mera fantasia (ópio do povo cuja verdadeira função está alhures), já não é simples fuga (de um mundo definido principalmente por objetivos e estruturas mais concretos), já não é passatempo das elites (portanto, irrelevante para as vidas da gente comum), já não é mera contemplação (irrelevante para novas formas de desejo e subjetividade), a imaginação tornou-se um campo organizado de práticas sociais, uma maneira de trabalhar (tanto no sentido do labor como no de prática culturalmente organizada) e uma forma de negociação entre sedes de ação (indivíduos) e campos de possibilidade globalmente definidos. (...) A imaginação está agora no centro de todas as formas de ação, é em si um fato social e é o componente-chave da nova ordem global (APPADURAI, 2004, p. 48)

Appadurai, por exemplo, percebe o uso intensivo da imaginação como elemento fundante daquilo que ele denomina (a partir da teoria de "comunidades imaginadas" do antropólogo britânico Benedict Anderson) "mundos imaginados", camadas de imaginações historicamente situadas de pessoas e grupos espalhados pelo globo (APPADURAI, 2004, p. 51).

Para ele, inclusive, os atuais fluxos culturais globais podem ser explicados pela disjunção entre estes mundos imaginados (chamados por ele de paisagens: etnopaisagem, tecnopaisagem, mediapaisagem, financiopaisagem e ideopaisagem), que ora colidem, ora se superpõem, provocando uma série conflitos.

Entretanto, onde se encontra o ponto de inflexão? Entende-se que está no fato de que antes a imaginação e a fantasia eram utilizadas para normatizar 
condutas, para aparar as diferenças, para garantir a estabilidade de uma identidade proposta pelo Estado, pela religião, pelos costumes.

Sua presença, ainda que fundamental para a manutenção de toda uma estrutura coletiva de pensamento, mal era percebida. Ela camuflava-se sob uma concordância geral que a tomava não como uma fantasia, mas sim como a pura realidade.

Hoje, a fantasia e a imaginação emprestam coerência ao vivido, aglutinam, criam pontes e estabelecem novas conexões que, na ausência, falência ou crise dos grandes sistemas explicativos, servem como contraponto para a obtenção de sentido para a vida.

Em contraposição ao grande encantamento moderno, que hoje está trincado, em reação ao desencanto em relação às grandes narrativas, essa capacidade imaginativa e fantasiosa se exprime numa outra dimensão. Ao menos no plano cotidiano, ela opera hoje febrilmente para reencantar o mundo dentro de parâmetros mais modestos, porém mais tangíveis.

Por exemplo, pululam exemplos de pessoas com orientações muitas vezes extremamente conflitantes, com perspectivas distintas dentro das paisagens de Appadurai - elas próprias microcósmicas disjunturas, mas que, com o emprego da fantasia, exercem suas escolhas e manejam suas heranças de modo a se apaziguarem e se inserirem no mundo.

Aliás, a bem da verdade, quase ninguém escapa dos pequenos curtocircuitos identitários, das disjunções pontuais, dos conflitos e mal-estares gerados pela oposição entre diferentes papéis, num mundo que perdeu boa parte do seu norte e que hoje aponta simultaneamente em várias direções.

Um exemplo radical e caricato desse tipo de comportamento (porém ilustrativo daquilo que, em menor grau ou de maneira não tão evidente, é vivido e experimentado por todos os indivíduos em suas existências diárias), é o dos Neonazistas Russos Gays (CHESTER, 2013). 
Em entrevista concedida ao site Vice, Balu (um dos membros de uma comunidade que, segundo ele, conta com 1500 pessoas apenas em Moscou) discorre com naturalidade sobre três temas que, ao menos no senso comum, dificilmente encontram convivência: nazistas, russos e gays. Ele, entretanto, consegue articular um discurso que, ao menos para si, supre as brechas entre essas três posições aparentemente tão antagônicas.

Para Balu, por exemplo, Hitler adotou medidas punitivas contra os homossexuais por pressão da conjuntura da época e não por sua vontade própria. Do mesmo modo, enxerga-se não como russo, mas sim como pertencente ao povo ariano, dissolvendo a diferença entre germânicos e eslavos. E entende o homossexualismo como uma expressão extrema de masculinidade, de trato viril entre iguais, realizando aí uma torção espetacular, já que tanto a cultura nazista quanto a cultura russa são fortemente machistas.

Risível? O caso deste neonazista, entretanto, está longe de se configurar como uma patologia solitária, ou restrita aos membros de uma seita.

Pesquisa realizada em 2012 pela Universidade Livre de Berlim (OPERA MUNDI, 2012) apontou que, dentre os 2.700 estudantes alemães de 15 e 16 anos inquiridos na pesquisa, cerca de $50 \%$ não sabiam que Hitler havia sido um ditador. Na verdade, para um terço deles, Hitler era um benfeitor dos direitos humanos. Diante disso, será ainda possível falar de um sentido histórico comum? Como se encaixará Hitler, uma das figuras mais universalmente odiadas da História Contemporânea, no universo imaginário desses estudantes?

Mal comparando, é como se, diante de um tabuleiro de xadrez, o oponente simplesmente movesse suas peças fora das regras prescritas, sem respeitar o sistema de turnos, sem sequer suspeitar que aquele tabuleiro e peças fazem parte de um jogo - num encerramento dentro de si que não reconhece parceiro e nem regra, a não ser as suas próprias.

Num ato de refundação, o uso contemporâneo da fantasia permite às pessoas reunir as peças do antigo jogo civilizatório de acordo com sua 
conveniência, para que elas possam criar, elas mesmas, o seu jogo, o seu sentido particular para a vida.

O que esses - e muitos outros - comportamentos demonstram é a crise de toda uma estrutura de valores que compunham o território comum por onde transitava a racionalidade do mundo. E que o recuo, ausência ou falência desses valores e relatos lança os indivíduos numa existência governada preponderantemente pela fantasia e pela imaginação, tanto aquela gerada pelo indivíduo em suas próprias digressões, quanto aquelas elaboradas por seus grupos particulares de referência, pela onipresente cultura pop ou ainda outros agentes comprometidos com o estabelecimento de verdades conforme seus interesses - tanto comerciais quanto políticos.

É nesse sentido que a fantasia torna-se elemento fundamental na construção da identidade contemporânea. "A identidade experimentada, vivida, só pode se manter unida com o adesivo da fantasia" (BAUMAN, 2001).

Aliás, como reforço, o uso contemporâneo da fantasia como elemento formador da identidade ganhou um poderoso aliado. $O$ vertiginoso crescimento da indústria cultural ao longo do século XX e a cada vez mais abrangente esfera simbólica gerada por esse aparato contribuiu decisivamente para elevar a imaginação dos indivíduos para limites nunca antes experimentados.

Vive-se hoje num mundo ineditamente prenhe de fantasia, onde a imaginação é hiper-estimulada como nunca. Um mundo onde os simulacros campeiam e disputam acirradamente com o mundo real a atenção dos viventes.

Vive-se hoje numa sociedade onde o faz-de-conta adensou-se sob a forma dos efeitos especiais dos filmes e pelas simulações oferecidas pelos jogos eletrônicos. Onde, cotidianamente, mundos paralelos, mostrados nas séries de TV e nas novelas, cruzam a fronteira da realidade nas residências, tornando seus espectadores observadores privilegiados de dramas fictícios. Onde telejornais, em sua pretensa seriedade, apresentam um pout-pourri de imagens e fatos que, verdadeiramente, são muito mais componentes para o 
estabelecimento de uma "ilusão de informação" do que efetivamente uma amostra da realidade. Onde desenhos animados e os mais esdrúxulos personagens infantis povoam o imaginário das crianças desde a mais tenra idade. Onde toda uma sorte de gadgets eletrônicos oferecem um ambiente auto-referente de interação. E onde, finalmente, nas teias comunicacionais eletrônicas, bilhões de pessoas (e suas personas) transitam dentro de modalidades de interação que há muito ultrapassaram qualquer semelhança com um referencial do mundo físico.

Na clássica referência sobre mapa e território (BAUDRILLARD, 1991, p. 8), proposta por Baudrillard a partir de um conto de Borges, como não concordar que a fantasia (o mapa), cada vez mais prescinde do real (o território)?

O mapa, de fato, ganha vida própria, é auto-referente, não mais é escravo de um original. É puro simulacro, sustentado pelo abundante manancial provido pela fantasia, pelo imaginado, pelo onírico. É campo privilegiado de onde se pode vislumbrar a força e a ubiquidade com que esse elemento - a fantasia hoje desempenha um papel preponderante nas relações sociais e na composição da identidade individual.

\section{9.- IDENTIDADE E ONIPOTÊNCIA}

O convite à onipotência torna-se, dentro deste cenário, cada vez mais tentador para os participantes dessa dinâmica social. Afinal, a composição da identidade torna-se, mais e mais, fruto de uma escolha pessoal, em detrimento de situações, posições e deveres herdados.

Como já visto, há uma cultura consumista que adula e joga com o ego dos indivíduos ininterruptamente, reforçando a sensação de que o mundo pode ser moldado a partir dos gostos e vontades do indivíduo. E há ainda um recuo das instituições que antes abrigavam e davam sentido à existência, tornando a 
tarefa de existir um problema cada vez mais concernente à consciência e à escolha de cada um.

Nesse sentido, ao elaborar a identidade a partir de si, o que resulta é não é um sentimento de potência, mas sim de onipotência, na medida em que não existe força moral que se anteponha à vontade do indivíduo.

Este foco no eu e no processo reflexivo, que se manifesta numa miríade de escolhas cotidianas, é o que coloca Anthony Giddens, em seu livro "Identidade e Modernidade", quando comenta a intensificação dessa dinâmica dentro do cenário contemporâneo.

O pano de fundo é o terreno existencial da vida moderna tardia. Num universo social pós-tradicional, organizado reflexivamente, permeado por sistemas abstratos, e no qual o reordenamento do tempo e do espaço realinha o local com o global, o eu sofre mudança maciça. (...)

No nível do eu, um componente fundamental da atividade do dia-a-dia é simplesmente o da escolha. Obviamente nenhuma cultura elimina inteiramente a escolha dos assuntos cotidianos, e todas as tradições são efetivamente escolhas entre uma gama indeterminada de padrões possíveis de comportamento.

Mas, por definição, a tradição, ou os hábitos estabelecidos, ordena a vida dentro de canais relativamente fixos. A modernidade confronta o indivíduo com uma complexa variedade de escolhas e ao mesmo tempo oferece pouca ajuda sobre as opções que devem ser selecionadas. (GIDDENS, 2002, p. 79)

É nesse sentido, quando a construção da identidade atinge uma feição altamente reflexiva, que se formam as condições para que se manifeste a onipotência do eu.

Uma das maneiras mais evidentes pelas quais isso se exprime é através do desenvolvimento de um estilo de vida (a palavra em si já traz consigo a ideia de que a vida não é dada, mas sim construída), uma das marcas mais patentes do indivíduo, quando se fala de identidade. 
Um estilo de vida, resumidamente, pode ser definido como um conjunto de práticas, relativamente integradas, que o indivíduo elege, de modo que, no quadro geral, essas posturas the garantam um mínimo de coerência, Ihe permitam divisar uma narrativa pessoal (GIDDENS, 2002, p. 79).

É assim que os micro-atos, como que roupa utilizar, que comida comer, que tipo de música escutar, com quem manter relações, vão pincelando o quadro do cotidiano.

Não por acaso, essa palavra - estilo - tornou-se uma das chaves de codificação da existência, tanto na identificação grupal como na que tange à auto-referência.

Encontra-se seu uso tanto para definir o perfil de executivos no trabalho quanto no salão de cabeleiro, tanto nas tribos adolescentes quanto no vestuário, tanto na música quanto na programação de TV.

Ter e cultivar um estilo de vida tornou-se quase que uma condição sine qua non, independente da classe social ou da idade. Do mesmo modo, ser taxado como uma pessoa sem estilo, ou com um estilo de vida medíocre é uma das piores ofensas que alguém pode sofrer.

Outro exemplo de como a sensação de onipotência está presente na vida cotidiana está na inversão que ocorre hoje dentro do campo religioso.

Antigamente, de todas as atribuições e deveres que acompanhavam o indivíduo desde o nascimento, era a religião a pedra angular sobre a qual não se cogitava possibilidade de escolha. Firmemente entranhada na tradição, amalgamada no cotidiano e no ciclo de vida das famílias, pertencia-se a uma religião antes mesmo que o indivíduo tomasse consciência dela.

A relação com Deus era essencialmente a de descoberta e aceitação de uma verdade, no rastro oposto a qualquer tentativa de potência. Nessa conjuntura, a onipotência pertencia a Deus, e a submissão à sua vontade ao Homem. 
Já hoje, se há um reencantamento do mundo, ele absolutamente não se dá nos mesmos moldes de antigamente. Em primeiro lugar, há espaço para que os indivíduos simplesmente decidam não incluir a esfera religiosa dentro da sua biografia de vida, suprimindo qualquer relação com o divino.

Além disso, a eventual aceitação de uma verdade religiosa torna-se, ela também, uma escolha. E não uma escolha para a vida inteira, lavrada em pedra, mas sim uma escolha escrita na areia da praia, sujeita às marés e intempéries do indivíduo.

É assim que fiéis transitam entre sistemas de crenças completamente discrepantes entre si. No Brasil, por exemplo, é comum uma vida dupla entre a religião católica e a umbanda, ou entre a religião católica e a doutrina espírita. Ou a disputa feroz entre as igrejas pentecostais e os membros das religiões afro-brasileiras. Ou ainda a prática de cultos orientais, oriundos de uma tradição diferente da brasileira, como o Budismo ou Hinduísmo.

Dentro desta nova dinâmica, cada um tem a liberdade para agir como bem entende. Como comenta Ortiz (ORTIZ, 1991), hoje existe um verdadeiro mercado religioso, onde cada religião compete agressivamente para arrebanhar e manter seus fiéis.

Neste sentido, a onipotência não se encontra mais em Deus. A onipotência encontra-se no indivíduo, a ponto de, se aquele Deus não lhe parecer bom o suficiente para enfrentar as adversidades da vida, trocá-lo por outra divindade e outro sistema de crenças, ou, ainda, trocá-lo por nada.

Ou seja, dentro da acepção contemporânea, a vida é encarada como um objeto em construção, criada pelo individuo em sua pretensa onipotência. A vida não é apenas uma sina, um destino imposto, uma fatalidade, como era a vida de um vivente da Idade Média. A vida é algo manipulável. Suas raízes, com a ajuda da fantasia, podem ser amplamente retrabalhadas, de modo a reposicionar o indivíduo favoravelmente nos diversos planos em que atua. 
Daí deriva a sensação (embora não se efetive) de onipotência. A sensação de tudo poder, ainda que sua real potência seja limitada e frustrada por uma série de fatores e restrições sociais, econômicas e culturais. 


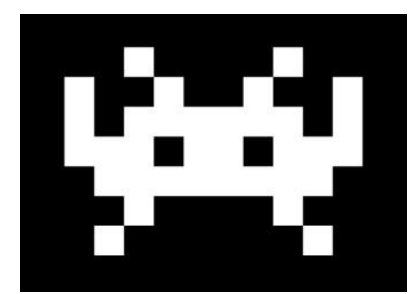

CAPÍTULO V:

\section{CONCLUSÃO}

\section{1. - CONCLUSÃO}

Todo este trabalho surgiu de uma indagação inicial: o que poderia explicar essa ascensão vertiginosa das práticas relacionadas ao uso dos jogos eletrônicos, a ponto dos chamados games caminharem para se tornar a forma preponderante de entretenimento na sociedade contemporânea?

Em princípio, a linha de investigação central era a de que o crescimento experimentado pelos jogos nas últimas décadas teria necessariamente de ser a expressão de alguma afinidade entre os jogos e o corpo social que os fruem, os sustentam e os legitimam cada vez mais.

Diversos autores (LIPOVETSKY, 2006) (MAFFESOLI, 2003) apontam para uma possível ludicização da sociedade, para um relaxamento geral das normas, para uma compreensão mais imediatista da vida, onde a existência se volta mais para o prazer do momento, para o estar-junto, do que empenhar-se na consecução de ideais de longo prazo. 
Seria a opção pelos jogos eletrônicos um sintoma dessa tendência que percorre o substrato social? Como pano de fundo explicativo, é possível se pensar dessa maneira.

Entretanto, essa visão bastaria para explicar o fascínio atual exercido pelos games? Se assim fosse, porque outras atividades também lúdicas, como o cinema, a TV, a música e a leitura não apresentam o mesmo ritmo de crescimento experimentado pelos jogos eletrônicos no cenário atual?

As raízes explicativas dessa questão não poderiam ser reduzidas apenas a uma ludicização geral da sociedade. Teria de haver alguma característica particular do jogo que permitisse aclarar melhor essas razões.

O fascínio da sociedade pelos jogos eletrônicos teria de ser explicado mergulhando-se diretamente naquilo que o jogo, em sua expressão mais ampla, possuísse de único, de singular, em contraste com outras formas de entretenimento. $\mathrm{O}$ jogo teria de ser estudado em sua forma, na maneira particular pela qual move suas engrenagens.

O que o jogo possui de singular em relação a outras expressões lúdicas encontradas na sociedade? Uma das chaves de desvendamento foi captada na opinião do gamer [deleted]:

Simples: o jogo permite realizar coisas espetaculares. Num livro, você imagina coisas espetaculares acontecendo. Num vídeo, você vê coisas espetaculares acontecendo. Num jogo, você FAZ coisas espetaculares (ASKREDDIT, 2013).

A julgar por esse depoimento, o que deveria ser considerado como a chave para o progresso da investigação era a forma sob a qual o entretenimento se apresentava. Jogar era mais recompensador porque 0 jogador via-se no centro da ação, ao invés de meramente acompanhar a ação como um espectador.

Mas se jogar é ação, é performance, é essencialmente um fazer (HENRIOT, 1989), ele não é um fazer desprovido de objetivo. Todo jogo possui 
um sentido, uma meta, algo que desafia o jogador, que o convida a experimentar o jogo. O fazer do jogo se inter-relaciona com a meta que o jogo propõe.

Entra aí a questão da escolha. Escolha após escolha, o jogador vai pincelando o quadro geral daquela experiência de jogo na qual adentrou. É o ato de escolher que, pouco a pouco, dissolve a incerteza do jogo, até seu desfecho. É o ato de escolher a força-motriz, o processo fundamental que dá andamento ao jogo.

O protagonismo contido na escolha pode, de fato, ser tomado como um diferencial diante de outras formas de entretenimento contemporâneo, que preconizam outras formas de interação.

Mas, por que o ato de escolher - e não o ato de simplesmente fruir, de observar, de colocar-se como espectador - tornou-se o ato cobiçado, o fator diferenciador, o elemento preponderante? A que práticas sociais contemporâneas essa preferência pela escolha estaria atrelada?

Baumann (BAUMAN, 2008), em seu texto sobre o Homo Eligens e sua incansável e escravizante capacidade de escolher, forneceu o primeiro ponto de aproximação teórica entre o universo do jogo e uma interpretação sobre a dinâmica social contemporânea. Giddens e Lipovetsky, por caminhos diferentes. também entenderam que a escolha tornou-se central em ao menos dois grandes processos vivenciados na modernidade: a forte tendência ao consumismo e a constituição da identidade dentro de um contexto de incerteza geral.

Estabeleceu-se aí a ponte teórica fundamental que atrelava a prática do jogo à dinâmica geral da sociedade. O que faz da escolha algo tão caro aos jogadores é que, afinal, eles pertencem a uma sociedade de Homo Eligens onde a escolha é a prática social predominante.

Ainda assim, algo faltava. Jogar possui uma coloração específica. Assim como a música produz som e sinestesia, o jogo produz seus próprios frutos. $\mathrm{E}$ 
isso, de alguma maneira, deveria ter alguma relevância para quem optasse pelo jogo.

Dos fóruns de discussão dos jogadores, mais uma vez, emergiram as respostas. "Jogar é divertido" (diversão). "Jogar é pura fantasia" (fantasia). "Sinto-me importante quando venço" (onipotência). Qualquer pessoa que já tenha jogado uma vez na vida - ou seja, qualquer um - é capaz de identificar essas três qualidades pulsando no jogo.

Mas seriam essas qualidades intrínsecas ao jogo, ou seriam fruto de uma determinada apreciação contemporânea do jogar?

Os diversos relatos históricos contidos neste trabalho reivindicam que não. Essas são características profundamente arraigadas aos jogos, percebidas por muitos povos e culturas diferentes. Elas atravessam diversos períodos históricos e atravessam também diversas retóricas de jogo, que as valoram positiva ou negativamente - mas não as desconsideram.

Assim, a conexão entre sociedade e jogo não se restringiria a uma forma semelhante (escolha), mas também se reforçaria por conta de uma afinidade entre o que a sociedade atualmente busca e aquilo que o jogo sempre soube oferecer.

Mais do que povoada pelos Homo Eligens, a análise guiada principalmente por Bauman, Lipovetsky e Guiddens revela também uma sociedade que, por diversas razões, é faminta por diversão, alimentada por doses maciças de fantasia e adepta de mecanismos que exaltam uma pretensa onipotência.

Finalmente, a última chave para explicativa surgiu da constatação de que, sem a TICs (Tecnologias de Informação e Comunicação) estruturando essa relação entre jogo e sociedade, esse enorme crescimento dos games como prática social não teria sido possível.

Mas qual seria o grau de afinidade entre os jogos e as TICs? De algum modo, isso poderia também ser um elemento de influência na explicação desse 
crescimento dos jogos? A resposta a essa questão, fornecida no capítulo III, demonstra que a natureza de operação do meio digital é coincidentemente muito semelhante à maneira pela qual o processo do jogo se manifesta.

O ambiente digital provou-se um meio através do qual o jogo expressa-se com grande desenvoltura. E se nas últimas décadas as TICs enraizaram-se por todos os meandros do corpo social, essa aliança inconteste com a tecnologia ofereceu ao jogo salvo-conduto para infiltrar-se na sociedade com o mesmo vigor.

Por isso, o desvendamento da questão proposta neste trabalho - as razões para o crescimento vertiginoso dos jogos na sociedade contemporânea foi construído considerando três vetores: jogos, sociedade e TICs.

Concluindo, como McLuhan já havia expresso com genialidade na década de sessenta: o meio é a mensagem. A forma, mais do que o conteúdo embutido nela, é a definidora dessa prevalência dos jogos eletrônicos sobre outros meios.

Essa preponderância explicativa da forma manifesta-se no fato de que jogo é escolha, e hoje vive-se pela escolha. Da mesma maneira, o jogo ressignificou-se sob a égide das TICs. E uma das condições de êxito dentro da dinâmica social atual é fazer com que tudo se apresente sob esse manto tecnológico.

Finalmente, ainda a partir da questão da forma, o crescimento expressivo experimentado pelos games deve-se à similitude entre características profundamente arraigadas ao jogo (diversão, fantasia, onipotência) e práticas sociais estruturadas também no uso maciço da diversão, da fantasia e da sensação de onipotência. A sociedade, hoje, identifica-se no jogo. Ela tem no 
jogo o seu doppelgänger ${ }^{6}$. A sociedade usufrui do jogo como um espelho de si mesma.

Comprova-se a hipótese: é a profunda afinidade de forma e similitude de valores entre o jogo, a sociedade contemporânea e as TICs que explica o crescimento exponencial dos jogos eletrônicos como forma de entretenimento.

\footnotetext{
${ }^{6}$ Nota do Autor: Segundo as lendas germânicas de onde provém, é um monstro ou ser fantástico que tem o dom de representar uma cópia idêntica de uma pessoa que ele escolhe ou que passa a acompanhar. Ele imita em tudo a pessoa copiada, até mesmo as suas características internas mais profundas. 0 nome Doppelgänger se originou da fusão das palavras alemãs doppel (significa duplo, réplica ou duplicata) e gänger (andante, ambulante ou aquele que vaga)" (WIKIPEDIA, 2014).
} 


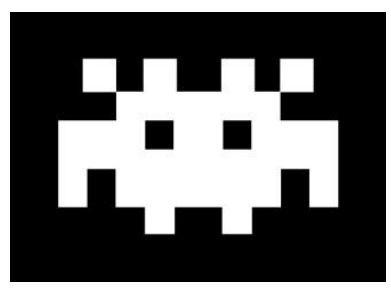

BONUS PHASE:

\section{A ERA DOS GAMES}

\subsection{GAMES: COMUNICAÇÃO LÚDICA DE MASSA}

Há ainda uma questão final que paira sobre este trabalho: seria essa convergência entre jogos, sociedade e TICs suficientemente potente para deflagrar uma "Era dos Games"?

Como exposto, já se divisam os contornos de uma "Era dos Games" a partir de deste primeiro fenômeno, que é a constatação de que o jogo eletrônico projeta-se, a partir de sua afinidade com a tecnologia e com os valores cultivados no campo social, como uma pujante e massiva forma de entretenimento.

Porém, para além do jogo como entretenimento, o termo "Era dos Games" reflete também um segundo fenômeno, que é o fato dos jogos eletrônicos, em sua ancoragem social, darem vazão a uma inédita materialização em larga escala da fantasia, operando como um meio de massa e criando um novo campo de realidade liminóide (TURNER, 2011), regido pelas regras de uma 
anti-estrutura (a realidade do jogo).

O jogo, como já visto, tem a capacidade de materializar a fantasia. E ele a tangibiliza de maneira mais intensa do que outros mecanismos de expressão fantasiosa, como os livros, os filmes ou a música. A razão pela qual o jogo materializa a fantasia é porque, graças à sua engrenagem, o jogo estabelece-se não no âmago do fantasioso, como talvez apenas a música, em sua sinestesia, consiga alcançar; nem apresenta o fantasioso como uma miragem, como o faz o cinema. O jogo opera necessariamente na fronteira entre a fantasia e a realidade (FINK, 2008).

Fantasia porque, por um lado, o campo de jogo manifesta-se no onírico, no simbólico. Realidade porque, por outro, seus mecanismos dependem de ações efetivas do jogador, ou jogadores, para se realizar. Como bem definido por Juul, o jogo é "half-real" (JUUL, 2005).

O fenômeno inédito encontra-se no fato da fantasia, materializada no jogo a partir da ação das TICs, passar a cumprir não apenas a tarefa de cenário para o transcorrer do jogo, mas também passar a operar como um campo mais amplo para expressão e comunicação dos indivíduos, para a vivência da vida, levada a cabo dentro dos próprios termos fantasiosos do jogo.

Esse fenômeno não pode ser confundido com o recente processo de virtualização da realidade, fruto da profunda ancoragem das TICs no campo social, principalmente a partir da otimização das redes telemáticas ao longo das duas últimas décadas.

Invadido pelas TICs, o corpo social muitas vezes percebeu essa virtualização como algo oposto ao real. Hoje, se aceita como real tanto o virtual quanto a realidade física. O virtual, longe de ser uma oposição, manifesta-se como um prolongamento imaterial de um real (CASTELLS, 2002).

Mas em que a realidade fantasiosa proporcionada pelos jogos diferenciase da realidade virtual oferecida pela disseminação das TICs? Através da intencionalidade de quem se dispõe a jogar. 
Aqueles que utilizam as TICs para exercer a socialidade virtual ainda estruturam sua experiência a partir do real, mesmo que se expressem de uma maneira fantasiosa. Sua base de referência é a realidade exterior.

Já aqueles que jogam, pelo contrário, ancoram-se firmemente na fantasia, ainda que a fantasia se valha de alguns elementos reais. Isso ocorre porque os jogadores, quando jogam, dispõem-se conscientemente a abandonar a realidade exterior em função da realidade do jogo, como já argumentado anteriormente.

Em outras palavras, mesmo que o jogo manifeste-se no virtual, como é o caso dos jogos eletrônicos, ainda assim sua condição de imersão permanece inalterada. Adentra ao jogo apenas aquele que concede à realidade do jogo primazia sobre a realidade exterior - seja ela uma realidade expressa através de uma realidade física, seja ela uma realidade expressa através da virtualidade.

Portanto, ao associar-se com as TICs, o jogo não apenas potencializou-se como entretenimento. O jogo opera também como um meio de comunicação de massa peculiar, capaz de oferecer a seus participantes os mesmos recursos de comunicação do plano virtual, mas um meio que se expressa em seus próprios termos, no puro terreno da fantasia, na realidade do jogo.

Que termos são esses? São os mesmos que definem o jogo como linguagem, segundo a apreciação de Bateson e Sutton-Smith (pg.48).

Primeiro, jogar estabelece-se como uma ação expressiva. Uma expressividade que se inicia na escolha de um nickname, que se enriquece na escolha do avatar, que avança para uma performance de jogo particular (cada jogador possui um estilo de jogo, com movimentações particulares, estratégias diferentes, etc..), que se elabora nos fóruns através de um linguajar estilizado.

Segundo. Jogar é, essencialmente, uma ação, um fazer. Jogar é, em si, em seu desenrolar, também uma ação comunicativa. 
Jogar Resident Evil com meu pai quando eu era mais jovem, e muito novo e assustado para jogar sozinho, é uma de minhas memórias mais preciosas. Festas regadas a Halo com meus camaradas foram uma das coisas mais divertidas que eu fiz no colégio. E hoje jogar LittleBigPlanet com minha namorada me faz ridiculamente feliz. Jogos possuem essa estranha capacidade de impactar você tão poderosamente, quer esteja jogando sozinho ou com outros. Eles moldam a própria pessoa que você se torna, ou aproxima as pessoas como nenhuma outra coisa consegue. (GIANT BOMB, 2011)

Terceiro, jogar é uma forma paradoxal de comunicação. Um bom exemplo disso é que, nesse campo fantasioso, congregar-se, muitas vezes, significa "matar" seus companheiros de jogo inúmeras vezes durante uma sessão de "Counter-Strike", embora nenhum jogador queira de fato matar o outro.

Quarto, jogar manifesta uma alternância entre a realidade do jogo e a realidade exterior. Essa condição, por exemplo, se cumpre frequentemente nos jogos online, especialmente quando os jogadores possuem algum nível de relacionamento entre si. Ao jogar, acaba-se também colocando na mesa de jogo diversos outros aspectos da vida, que brotam muitas vezes no decorrer da experiência (VESA, 2013).

Quinto, o jogo tem a capacidade de transportar em si diversas emoções subjacentes, e de expressá-las em sua própria linguagem - como por exemplo através da ação, da performance.

É emblemático o caso do filho que, seis anos após a morte do pai, descobriu que a performance de seu progenitor permanecia gravada num jogo de corrida, em modo "ghost"' . A maneira encontrada pelo jovem para se relacionar com a figura do falecido pai foi apostar corridas contra a performance dele, até o momento em que o superasse. Entretanto, sabedor

\footnotetext{
${ }^{7}$ Nota do Autor: diversos jogos de corrida registram a melhor volta feita, imortalizando a performance do jogador no chamado "ghost mode" (modo fantasma). Todos os outros jogadores, enquanto estão na pista, percebem a silhueta do carro que quebrou o recorde. É uma maneira de poderem comparar suas performances. Quando um jogador supera a performance anterior, sua performance torna-se o novo "ghost" do jogo.
} 
que se cruzasse a linha de chegada sua performance tomaria o lugar da anterior, o filho disputava com a performance do pai, mas quando chegava próximo à linha de chegada, freava o carro, para nunca vencer - e nunca apagar essa memória de seu progenitor (THE DAILY DOT, 2014).

Enfim, é essa condição de mídia de massa experimentada pelo jogo, a partir da junção de suas propriedades como linguagem com suas capacidades enquanto mídia é que permitem afirmar que o termo "Era dos Games" não apenas é fruto da popularização do jogo como entretenimento.

A "Era dos Games" reflete também esse segundo fenômeno: a inauguração de uma "comunicação lúdica de massas", realizada a partir do uso do ambiente de jogo como meio de comunicação, como um novo território de pertencimento. Um ambiente liminóide de fantasia tornado tangível pela tecnologia, que exige de seus frequentadores uma intencionalidade particular para ser usufruído.

\subsection{GAMES: IDEAL CONTEMPORÂNEO DO LÚDICO}

Finalmente, a "Era dos Games" abriga um terceiro fenômeno: os jogos eletrônicos tornaram-se, para a sociedade, a forma exemplar de lúdico a ser almejada e imitada. Esse processo é alavancado tanto pela deflagração do jogo eletrônico como fenômeno massivo de entretenimento, quanto pela condição do jogo eletrônico como meio de comunicação de massa.

Como já apontado, diversos autores argumentam que um dos traços mais evidentes da sociedade contemporânea é a sua aproximação com o lúdico.

Lipovetsky, por exemplo, percebe claramente a associação entre e consumo e jogo. 
Hoje, no Homo consumans há mais do que nunca o Homo ludens, sendo o prazer do consumo análogo ao proporcionado pelas atividades de jogo. Não há nenhuma dúvida de que essa capacidade de criar distração lúdica e movimento 'interior' seja um dos grandes fatores que alimentam a interminável escalada das necessidades (LIPOVETSKY, 2007, p. 68)

Mafesolli, por sua vez, em sua defesa do Ludismo como uma força que permeia toda a nossa dinâmica social, aponta:

A luta econômica, a emulação pecuniária, a teatralidade política parecem atestar que nada escapa ao jogo do mundo, que as sociedades são formadas por ele e que levá-lo em conta não é uma posição de esteta, mas o reconhecimento de uma constante que, em diagonal, atravessa todas as realidades humanas (MAFFESOLI, 2003, p. 26).

Enfim, segundo Lhote, o princípio contemporâneo da organização social é lúdico e transforma em jogo tudo o que resulta dele (LHÔTE, 1994, p. 364).

Dentro desse contexto, o que se advoga é que os jogos eletrônicos, a partir da extraordinária relevância que exercem hoje no corpo social, passaram gradativamente a encarnar, aos olhos da sociedade, a quintessência do lúdico.

De fato, os jogos eletrônicos são uma das expressões mais vigorosas do lúdico na era contemporânea, mas estão longe de serem seus representantes exclusivos. Os esportes, por exemplo, representam outro ramo do lúdico bastante influente, mas que não captura a imaginação da sociedade tanto quanto os games.

Ora, numa sociedade onde cada vez mais tudo o que se declara lúdico ganha legitimidade, e onde os games são considerados como a maior expressão do lúdico, é consequência natural que tudo o que se apresente como game ou faça referência aos games goze, portanto, de aceitação cada vez mais generalizada.

Setores importantes da indústria cultural já atentaram para isso. Steven Spielberg e Ridley Scott, dois dos mais influentes diretores de Hollywood, 
anunciaram em agosto de 2014 dois projetos com a marca Halo, um dos games mais populares do mundo, com mais de 55 milhões de unidades vendidas. Spielberg produzirá uma série de TV a partir do enredo do game. Scott fará um filme que tem como função apresentar o protagonista do próximo game da série, "Halo 5: Guardians" (ROLLING STONE, 2014). Qual indústria está a reboque da outra?

Nas agências de publicidade, por exemplo, o game passa a ser emulado cada vez mais em sua estética, como no anúncio do novo Uno (PORTAL DA PROPAGANDA, 2011).

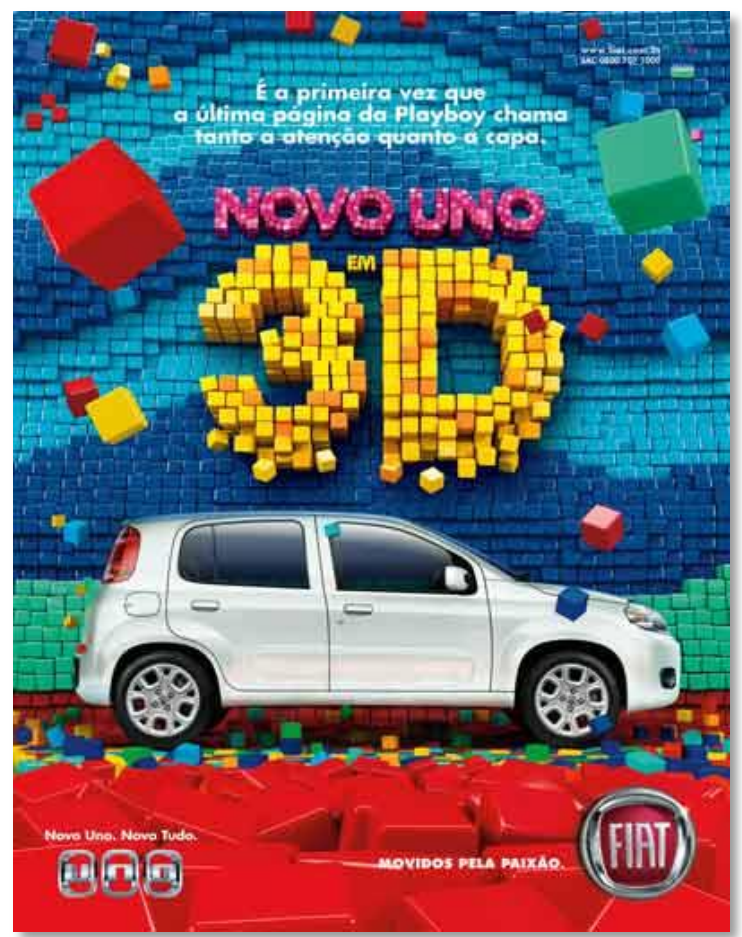

Figura 13: anúncio do novo Uno 
Aplicativos como populares como Tinder, Foursquare, Pinterest emulam, em sua lógica e mesmo em sua estética, a cultura dos games.

Os jogos eletrônicos vem se tornando, nesse contexto social, moeda de legitimação em diversas outras instâncias que não tem quase ou mesmo nenhuma afinidade com o jogo.

Um bom exemplo que confirma essa tendência de nomear qualquer processo como game encontra-se no uso das chamadas "Gamification techniques", que invadiram não só as agências de publicidade, mas também o ambiente escolar e o mundo corporativo. A definição da Wikipedia exprime bem essa flutuação da estética e da lógica de jogo para além de sua perspectiva original.

Gamification é o uso da lógica dos games e de mecânicas dos games em contextos de não-jogo para engajar os usuários a resolver problemas. Gamification tem sido estudada e aplicada em diversas áreas. Alguns de seus propósitos principais são engajar (aumentar o engajamento do usuário, exercício físico, retorno do investimento, fluxo, qualidade das informações, pontualidade), ensinar (em salas de aula, em público e no ambiente de trabalho), entreter (provocar euforia, lealdade), mensurar (no recrutamento e na avaliação de funcionários) e aumentar a facilidade de uso de sistemas de informação. (WIKIPEDIA, 2014)

Ora, Skinner e Pavlov, representantes do Behaviorismo, já aplicavam esse tipo de técnica desde o início do século XX. Porém, sob a nova chancela dos games, esse ramo da psicologia ganha uma nova roupagem e renova-se mesmo que a mecânica básica de estímulo-recompensa, espinha dorsal tanto do Behaviorismo quanto da Gamification, represente o que de mais pobre o universo dos jogos têm a oferecer.

Enfim, essa idealização dos games pela sociedade, na qual o jogo eletrônico passa a ser internalizado em sua estética e em sua lógica, a ser buscado como elemento de legitimação, é o terceiro fenômeno que caracteriza a "Era dos Games". 
Em resumo, a "Era dos Games" caracteriza-se por:

a) Vertiginoso crescimento dos games como prática majoritária de entretenimento.

b) A partir das práticas de entretenimento, mas já para além delas, a inauguração de uma "comunicação lúdica de massas", realizada a partir do uso do ambiente de jogo como meio de comunicação, como um novo território de pertencimento.

c) Derivada das práticas de entretenimento e de pertencimento geradas pelos games, uma idealização na qual o jogo eletrônico passa a ser internalizado em sua estética e em sua lógica, tornando-se objeto de legitimação social.

\subsection{RETÓRICAS DO JOGO EM REORDENAÇÃO}

Os games - expressão eletrônica do jogar, expressão contemporânea do jogar - operam como a ponta-de-lança, o elemento concretizador que causa uma reordenação das retóricas que valoram o jogo no campo social. Essa seria a reverberação mais ampla de suas práticas no corpo social.

E qual tem sido o pensar sobre o jogo da sociedade contemporânea? Até recentemente, segundo Sutton-Smith, a retórica hegemônica sobre o conceito de jogo foi a que percebe o jogo como frivolidade, "a mais forte e a mais duradoura de todas as retóricas sobre jogo nos últimos quatrocentos anos" (SUTTON-SMITH, 2001, p. 7),

Entretanto, como pontua Spariosu, experimenta-se um progressivo retomar de conceitos mais amplos de jogo. "Desde o fim da Era da Razão, valores pré-racionais têm se inserido gradualmente na filosofia Ocidental. Esse 
processo implica numa reversão dos valores Platônicos e Aristotélicos e um retorno a modos não-racionais do pensamento Pré-Socrático" pg. 162.

Atualmente, ganham força retóricas modernas que pensam o jogo, por exemplo, a partir da Imaginação e do Self. 0 jogo, através de pensadores como o pioneiro Huizinga "o primeiro a declarar o jogo uma função fundamental da condição humana, que permeia todas as culturas desde o início" (Sutton-Smith, 202), vem sendo paulatinamente dignificado em sua importância, revertendo um ostracismo histórico imposto pelo Puritanismo, pela ética do Trabalho e por valores Platônicos.

Nesse sentido, a emergência de uma "Era dos Games", com todas as implicações citadas anteriormente, obriga a sociedade a se reexaminar, mais uma vez, em sua turbulenta e multifacetada relação com o jogo. Nesse grande jogo pela hegemonia que se desenvolve entre diferentes retóricas, por certo haverá uma nova acomodação.

É provável que a retórica do jogo como Frivolidade perca terreno, enquanto retóricas que exaltem e ampliem a atual compreensão do que seja jogar ganhem relevância.

Isso inclui retóricas jovens, como as do Self, que encaram o jogo como, por exemplo, uma experiência autotélica (SUTTON-SMITH, 2001), mas também antiquíssimas retóricas, como a do jogo como Destino, que conseguem enxergar a vida como um grande jogo, fruto de um espírito criador e brincalhão, como é o caso espírito de Lilá indiano (SAX, 1995).

Quais os novos-velhos olhares que emergirão a respeito do jogar, a partir do impacto gerado pela ancoragem social dos jogos eletrônicos?

Quem sabe, nesse rearranjo retórico, a sociedade contemporânea possa, uma vez mais, se dar conta daquilo que Heidegger enxerga nas duras palavras do pensador grego Heráclito, quando, no templo de Ártemis, foi flagrado por seus conterrâneos jogando astrágalos com as crianças e assim respondeu:"Seus 
infames, o que estão olhando aqui tão espantados? Não é melhor fazer o que estou fazendo agora do que cuidar da polis junto com vocês?".

Para Heidegger, em sua interpretação desse fragmento,

o olho da multidão não se inclina para perceber aquilo que se mostra num olhar para além. [...] Como dizem os gregos, para o muito, aquilo que ultrapassa o olhar tem o valor de mera fantasia e invenção. As pessoas se atêm, em vão, ao 'real' e ao simplesmente dado". (HEIDEGGER, 1998)

A realidade do jogo (teria sido isso o que Heráclito, o obscuro, quis dizer?) é uma realidade tão real e relevante quanto a realidade exterior. Basta ter o olhar para além, para disso se aperceber. 


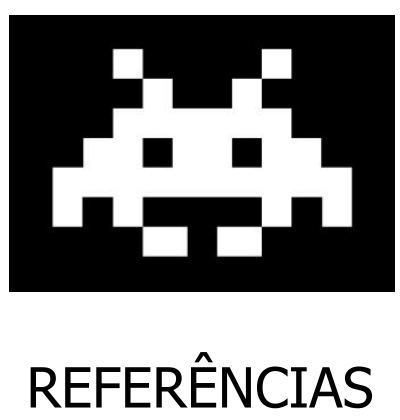

1. REFERÊNCIAS BIBLIOGRÁFICAS:

APPADURAI, A. Dimensões Culturais da Globalização. Lisboa: Teorema, 2004.

AVEDON, E. M.; SUTTON-SMITH, B. The Study of Games. Huntigton, New York: Robert E. Krieger, 1979.

BATESON, G. Steps to An Ecology of Mind. Chicago, Illinois: University of Chicago Press, 2000.

BAUDRILLARD, J. Simulacros e Simulação. Lisboa: Relógio D'água, 1991.

BAUMAN, Z. Modernidade Líquida. Rio de Janeiro: Zahar, 2001.

BAUMAN, Z. Identidade: Entrevista a Benedetto Vecchi. Rio de Janeiro: Zahar, 2005.

BAUMAN, Z. Vida Líquida. Rio de Janeiro: Zahar, 2007. 
BAUMAN, Z. Vida para Consumo. Rio de Janeiro: Zahar, 2008.

BAUMAN, Z. A Sociedade Individualizada. Rio de Janeiro: Zahar, 2009.

BOBBIO, N. A Era dos Direitos. São Paulo: Campus, 2004.

BROUGÈRE, G. Jogo e Educação. Porto Alegre: Artes Médicas, 1998.

BURGHARDT, G. M. The Genesis of Animal Play: Testing the Limits. Cambridge, Massachusetts: The MIT Press, 2006.

CAILLOIS, R. Man, Play and Games. [S.I.]: University of Illinois Press, 2001.

CANCLINI, N. G. Consumidores e Cidadãos. 4a. ed. Rio de Janeiro: Editora UFRJ, 1999.

CASTELLS, M. A Sociedade em Rede. 6a. ed. São Paulo, São Paulo: Paz e Terra, 2002.

DEBORD, G. A Sociedade do Espetáculo - Comentários sobre a sociedade do espetáculo. 9a. ed. Rio de Janeiro: Contraponto, 2007. ECO, U. Sobre os Espelhos e Outros Ensaios. Rio de Janeiro: Nova Fronteira, 1989.

FAGEN, R. Animal Play Behavior. New York: Oxford University Press, 1981.

FREUD, S. Sigmund Freud Obras Completas vol. 14. São Paulo: Editora Schwarcz, 2010.

GADAMER, H.-G. Verdade e Método I: Traços fundamentais de uma hermenêutica filosófica. 9a. ed. Petrópolis, Rio de Janeiro: Vozes, 2008.

GIDDENS, A. Modernidade e Identidade. Rio de Janeiro: Zahar, 2002.

GIOIELLI, R. L. P. Do Sólido ao Líquido: novas pistas para compreender a identidade. Novos Olhares, São Paulo, v. 1, n. 16a , p. 39-50, $2^{0}$ semestre 2005. 
HALL, S. A Identidade Cultural na Pós-Modernidade. 9a. ed. Rio de Janeiro: DP\&A, 2004.

HEIDEGGER, M. Heráclito. Rio de Janeiro: Relume Dumará, 1998 HENRIOT, J. Sous Couleur de Jouer - La Métaphore Ludique. [S.I.]: Jose Corti, 1989.

HUHTAMO, E. From Cybernation to Interaction: a Contribution to an Archaeology of Interactivity. In: LUNENFELD, P. The Digital Dialectic: New Essays on New Media. Cambridge, Massachusetts: MIT Press, 1999. Cap. 5, p. 96-110.

HUIZINGA, J. Homo Ludens. 5a. ed. São Paulo: Perspectiva, 2001.

JENCKS, C. What is Post-Modernism? London: Academy Editions, 1989.

JOÜET, J. Pratiques de communication et figures de la médiation - Des médias de masse aux technologies de l'information et de la communication. In: P., B., et al. Sociologie de la communication. Paris: Réseux/CENT, 1997. p. 291312.

KUMAR, K. Da Sociedade Pós-Industrial à Pós-Moderna: novas teorias sobre o mundo contemporâneo. Rio de Janeiro: Zahar, 1997.

LAUREL, B. Computer as Theatre. 2a. ed. Nova Jersey: Addison-Wesley, 2014.

LEMOS, A. Cibercultura: tecnologia e vida social na cultura contemporânea. 2a. ed. Porto Alegre: Sulina, 2004.

LHÔTE, J.-M. Histoire des Jeux de Société. Paris: Flammarion, 1994. LIPOVETSKY, G. A Era do Vazio - ensaios sobre o individualismo contemporâneo. $1^{\text {a }}$ reimpressão. ed. Barueri: Manole, 2006.

LIPOVETSKY, G. A Felicidade Paradoxal: ensaio sobre a sociedade de hiperconsumo. São Paulo: Companhia das Letras, 2007. 
LUNENFELD, P. Unfinished Business. In: LUNENFELD, P. The Digital

Dialectic: New Essays on New Media. Cambridge, Massachusetts: MIT Press, 1999. Cap. 1, p. 6-23.

MCGONICAL, J. Reality is Broken: Why Games Make Us Better and How They Can Change the World. New York: Penguin, 2011.

MCLUHAN, M. Os Meios de Comunicação Como Extensões do Homem. 20a. ed. São Paulo: Cultrix, 2011.

MIÈGE, B. A Sociedade Tecida pela Comunicação. São Paulo, São Paulo: Paulus, 2009.

MURRAY, J. H. Hamlet no Holodeck: o Futuro da Narrativa no Ciberespaço. São Paulo, São Paulo: UNESP, 2003.

ORTIZ, R. A Morte Branca do Feiticeiro Negro: Umbanda e Sociedade Brasileira. São Paulo: Brasiliense, 1991.

ORTIZ, R. Mundialização e Cultura. 5a. ed. São Paulo: Brasiliense, 2003. PIAGET, J. A Formação do Símbolo na Criança. Rio de Janeiro: [s.n.], 1988. POWELL, E. Freedom and Reality. Farnham: Elliot Right Way Books, 1969. ROUANET, S. P. As Razões do Iluminismo. 2a. ed. São Paulo: Companhia das Letras, 2008.

SALEN, K.; ZIMMERMMAN, E. Rules of Play: Game Design Fundamentals. Cambridge, Massachusetts: The MIT Press, 2004.

SAX, W. S. The Gods at Play. New York, New York: Oxford University Press, 1995.

SOUSA, M. W. D. Recepção e comunicação: a busca do sujeito. In: (ORG), M. W. D. S. Sujeito, o Lado Oculto do Receptor. São Paulo: Brasiliense, 1995. Cap. 1 , p. 13-38. 
SPARIOSU, M. I. Dionysus Reborn - Play and the Aesthetic Dimension in Modern Philosophical and Scientific Discourse. Ithaca, New York: Cornell University Press, 1989.

SUTTON-SMITH, B. Toys as Culture. Mattituck, New York: Gardner Press, 1986.

SUTTON-SMITH, B. The Ambiguity of Play. 2. ed. [S.I.]: Harvard University Press, 2001.

TURKLE, S. Life on the Screen. New York, New York: Simon \& Schuster, 1995.

VEJA. Games para os Avós. VEJA, São Paulo, n. 2265, p. 148, abr. 2012.

WEIZENBAUM, J. ELIZA: a computer program for the study of natural language communication between man and machine. Communications of the ACM (Association for Computing Machinery) 9, 1966. 36-45.

WINNICOTT, D. W. O Brincar e a Realidade. Rio de Janeiro: Imago, 1975.

WITTGENSTEIN, L. Investigações Filosóficas. São Paulo: Nova Cultural, 1999. 


\section{REFERÊNCIAS ELETRÔNICAS:}

ADNEWS. McDonald's estreia campanha "Que bom que você veio". AdNews, 2014. Disponivel em: <http://www.adnews.com.br/publicidade/mcdonald-sestreia-campanha-que-bom-que-voce-veio >. Acesso em: 13 jan. 2014.

BAIRON, S. A Rede e o Jogo. Casi Nada - Webmagazine, 1998. Disponivel em: <http://www.kendo-andorra.org/csn/25rede.htm>. Acesso em: 29 maio 2014.

BBC. BBC UK Games Research. BBC, 2005. Disponivel em:

<http://open.bbc.co.uk/newmediaresearch/2006/01/bbc_uk_games_research.h tml>. Acesso em: 20 jan. 2014.

CAIXA. Caixa Mastercard Platinum. CAIXA, 2014. Disponivel em:

<http://www.caixa.gov.br/voce/Cartoes/cartoes_platinum.asp>. Acesso em: 13 jan. 2014.

CHESTER, N. Uma Entrevista com um Neonazista Gay Russo. Vice, 2013. Disponivel em: <http://www.vice.com/pt_br/read/uma-entrevista-com-umneonazista-gay-russo>. Acesso em: 01 mar. 2014.

DFC INTELLIGENCE. DFC Intelligence. DFC Intelligence, 2011. Disponivel em: <http://www.dfcint.com/wp/>. Acesso em: 23 fev. 2014.

ÉPOCA. A maior diversão da Terra. Globo.com, 2012. Disponivel em: <http://revistaepoca.globo.com/ideias/noticia/2012/02/maior-diversao-daterra.html>. Acesso em: 8 mar. 2014.

ESA. Essential Facts about the computer and video game industry. The ESA, 2012. Disponivel em: <http://www.theesa.com/facts/pdfs/ESA_EF_2012.pdf> . Acesso em: 4 maio 2014. 
ESTADÃO. Jogos violentos podem alterar funções cerebrais. Link, 2011. Disponivel em: <http://blogs.estadao.com.br/link/jogos-violentos-alteramfuncoes-cerebrais-diz-estudo/>. Acesso em: 06 jun. 2014.

ESTADÃO. Jogo empresarial ajuda a escolher profissão. Estadão, 2012. Disponivel em: <http://educacao.estadao.com.br/noticias/geral,jogoempresarial-ajuda-a-escolher-profissao,906166>. Acesso em: 30 jun. 2014.

EXAME. O que é "Gamification"? Exame.com, 2011. Disponivel em: <http://exame.abril.com.br/pme/dicas-de-especialista/noticias/o-que-egamification>. Acesso em: 19 abr. 2014.

EXAME. A Vez dos Advergames. Exame, 2012. Disponivel em: <http://exame.abril.com.br/marketing/noticias/a-vez-dos-advergames>. Acesso em: 05 fev. 2014.

FOLHA DE SÃO PAULO. Games melhoram coordenação motora e boas maneiras da criança. Folha de São Paulo, 2004. Disponivel em: <http://www1.folha.uol.com.br/fsp/informat/fr2306200425.htm>. Acesso em: 22 maio 2014.

FOLHA DE SÃO PAULO. Jogador esfaqueia homem que matou seu personagem em game. Folha de São Paulo, 2010. Disponivel em:

<http://www1.folha.uol.com.br/tec/2010/05/743467-jogador-esfaqueiahomem-que-matou-seu-personagem-em-game.shtml>. Acesso em: 01 jul. 2014.

FOLHA DE SÃO PAULO. Brasileiro gosta mais de ação do que futebol em videogames, aponta pesquisa. Folha de São Paulo, 2012. Disponivel em: <http://www1.folha.uol.com.br/tec/1162610-brasileiro-gosta-mais-de-acao-doque-futebol-em-videogames-aponta-pesquisa.shtml>. Acesso em: 01 mar. 2014.

FOLHA DE SÃO PAULO. Grupo cristão promove boicote a jogos com personagens gays. Folha de São Paulo, 2012. Disponivel em: 
<http://blogdetec.blogfolha.uol.com.br/2012/04/11/grupo-cristao-promoveboicote-a-jogos-com-personagens-gays/>. Acesso em: 2 jul. 2014.

FOLHA DE SÃO PAULO. Mercado brasileiro de games já é o quarto maior do mundo e deve continuar a crescer. Folha de São Paulo, 2012. Disponivel em: $<$ http://www1.folha.uol.com.br/tec/1165034-mercado-brasileiro-de-games-ja-eo-quarto-maior-do-mundo-e-deve-continuar-a-crescer.shtml>. Acesso em: 07 jun. 2014.

FOLHA DE SÃO PAULO. Novos games tornam PlayStation 4 e Xbox One mais atraentes. Folha de São Paulo, 2014. Disponivel em:

<http://www1.folha.uol.com.br/tec/2014/06/1469981-novos-games-mudam-ocenario-de-titulos-para-xbox-one-e-playstation-4.shtml>. Acesso em: 20 jun. 2014.

G1. Japonês se casa com personagem de videogame em cerimônia no mundo real. Globo.com, 2009. Disponivel em:

<http://g1.globo.com/Noticias/Games/0,MUL1392691-9666,00.html>. Acesso em: 28 jun. 2014.

G1. Game 'Conflitos globais' tenta quebrar paradigma e colocar jogos na escola. Globo.com, 2010. Disponivel em: <http://g1.globo.com/Noticias/Games/0,MUL1534669-9666,00.html>. Acesso em: 15 fev. 2014.

G1. Mercado de games brasileiro cresce e vira oportunidade de negócios. Globo.com, 2012. Disponivel em:

<http://g1.globo.com/tecnologia/noticia/2012/10/mercado-de-games-brasileirocresce-e-vira-oportunidade-de-negocios.html>. Acesso em: 14 mar. 2014.

GAMES UNIVERSE BLOG. Estudo: Jogos de ação melhoram desempenho do cérebro. Games Universe Blog, 2012. Disponivel em: <http://www.gamesuniverse.com.br/?p=29777>. Acesso em: 4 jun. 2014. 
GOTTO, C. Why do we love video games? Venture Beat, 2013. Disponivel em: <http://venturebeat.com/2013/04/16/why-do-we-love-video-games/>. Acesso em: 18 jul. 2014.

IBM. Game industry changes and trends. IBM Developer Works, 2011. Disponivel em: <http://www.ibm.com/developerworks/library/ba-big-datagaming/>. Acesso em: 20 mar. 2014.

IGN. 100 Little Things in GTA 5 That Will Blow Your Mind. IGN, 2013.

Disponivel em: <http://www.ign.com/articles/2013/09/30/100-little-things-ingta-5-that-will-blow-your-mind>. Acesso em: 01 jun. 2014.

INFO EXAME. Saiba como os advergames podem promover uma marca. Info Exame, 2012. Disponivel em:

<http://info.abril.com.br/noticias/extras/advergames-01082012-44.shl>. Acesso em: 10 fev. 2014.

ISTOÉ. Os Games da Saúde. ISTOÉ, 2012. Disponivel em: <http://www.istoe.com.br/reportagens/241551_OS+GAMES+DA+SAUDE> . Acesso em: 05 jan. 2014.

ISTOÉ DINHEIRO. O jogo rentável dos games. ISTOÉ Dinheiro, 2008.

Disponivel em: <http://www.terra.com.br/istoedinheirotemp/edicoes/553/artigo87386-1.htm>. Acesso em: 17 fev. 2014.

KOTAKU. Why Do We Play Games? Kotaku, 2013. Disponivel em: <http://kotaku.com/why-do-we-play-games-458801312>. Acesso em: 20 jul. 2014.

MUCIOLI, F. Guinness elege os 50 mais famosos dos games; Bowser perde para o Capitão Price. Kotaku, 2011. Disponivel em:

<http://www.kotaku.com.br/guinness-elege-os-50-mais-famosos-dos-gamesbowser-perde-para-o-capitao-price/>. Acesso em: 28 maio 2014.

NEWZOO. NewZoo. NewZoo, 2012. Disponivel em: <Newzoo>. Acesso em: 05 fev. 2014. 
NPD GROUP. The U.S. Experiences Decline In Total Number Of Gamers. NPD Group, 2012. Disponivel em:

<https://www.npd.com/wps/portal/npd/us/news/press-releases/pr_120905/>. Acesso em: 30 jan. 2014.

OLHAR DIGITAL. Pesquisa: jogos em primeira pessoa melhoram atenção e visão dos usuários. Olhar Digital, 2012. Disponivel em:

<http://olhardigital.uol.com.br/noticia/jogos-em-primeira-pessoa-aumentaminteligencia-e-melhoram-a-visao-do-usuario/25821>. Acesso em: 20 jul. 2014.

PEGN. Mercado de games tem potencial para faturar R $\$ 3$ bilhões. Globo.com, 2011. Disponivel em:

<http://revistapegn.globo.com/Revista/Common/0,EMI216624-17180,00MERCADO+DE+GAMES+TEM+POTENCIAL+PARA+FATURAR+R+BILHOES.html >. Acesso em: 02 abr. 2014.

PEGN. Empresas em Jogo. Globo.com, não informado. Disponivel em: <http://revistapegn.globo.com/Revista/Common/0,EMI263126-17156,00EMPRESAS+EM+JOGO.html>. Acesso em: 1 maio 2014.

PERREAULT, G. Why Do We Love Video Games? Huffington Post, 2014. Disponivel em: <http://www.huffingtonpost.com/greg-perreault/why-do-welove-video-game_b_4740425.html>. Acesso em: 19 jul. 2014.

PEW INTERNET \& AMERICAN LIFE PROJECT. PEW Internet Project Data Memo. Pew Internet, 2008. Disponivel em: <http://www.pewinternet.org/files/oldmedia//Files/Reports/2008/PIP_Adult_gaming_memo.pdf.pdf>. Acesso em: 03 jun. 2014.

PEW INTERNET \& AMERICAN LIFE PROJECT. Teens, Video Games, and Civics. PEW Internet, 2008. Disponivel em:

<http://www.pewinternet.org/ /media/Files/Reports/2008/PIP_Teens_Games_ and_Civics_Report_FINAL.pdf.pdf>. Acesso em: 03 jun. 2014. 
PRICEWATERHOUSECOOPERS. Key Insights at a glance.

PricewaterhouseCoopers, 2011. Disponivel em:

<http://www.pwc.com/gx/en/global-entertainment-media-outlook/segmentinsights/video-games.jhtml>. Acesso em: 05 abr. 2014.

REDFERN, M. Wiring up the 'Victorian internet'. BBC News, 2005. Disponivel em: <http://news.bbc.co.uk/2/hi/science/nature/4475394.stm>. Acesso em: 11 jul. 2014.

SHARPE, L. So You Think You Know Why Animals Play.... Scientific American, 2011. Disponivel em: <http://blogs.scientificamerican.com/guestblog/2011/05/17/so-you-think-you-know-why-animals-play/>. Acesso em: 07 jan. 2014.

THE ECONOMIST. All the world's a game. The Economist, 2011. Disponivel em: <http://www.economist.com/node/21541164>. Acesso em: 30 mar. 2014. THE GAME THEORISTS. Game Theory: Why You Play Video Games. Youtube, 2013. Disponivel em: <https://www.youtube.com/watch?v=MyUC_28HIvA>. Acesso em: 18 jul. 2014.

UNITED STATES CENSUS BUREAU. United States Census Bureau. United States Census Bureau, 2013. Disponivel em:

<http://www.census.gov/popest/about/terms.html>. Acesso em: 05 maio 2014.

URSINI, N. Homem processa Unilever por não atrair mulheres. Meio \& Mensagem, 2014. Disponivel em:

<http://www.meioemensagem.com.br/home/comunicacao/noticias/2014/01/15 /Homem-processa-Unilever-por-n-o-atrair-mulheres.html>. Acesso em: 21 jan. 2014.

VIXIMO. Viximo. Viximo, 2012. Disponivel em: <http://viximo.com/>. Acesso em: 22 abr. 2014. 
WIKIPEDIA. Grand Theft Auto - Vendas. Wikipedia, 2014. Disponivel em: <http://pt.wikipedia.org/wiki/Grand_Theft_Auto_V\#Vendas>. Acesso em: 12 maio 2014.

WIKIPEDIA. World of Warcraft. Wikipedia, 2014. Disponivel em:

<http://pt.wikipedia.org/wiki/World_of_Warcraft>. Acesso em: 01 jun. 2014. 


\section{OBRIGADO, OBRIGADO, OBRIGADO!}

Mais uma vez, obrigado Tati, Anete e José. Foi incrível o suporte que vocês me deram em todas as pequenas grandes coisas do dia a dia, durante todos esses meses tão árduos e tão especiais, poupando-me para que eu pudesse estudar.

Revisão Técnica:

Anete Maria Alves Onça

Revisão Final:

José Antonio Có Onça,

Anete Maria Alves Onça

Design:

Tatiana Paiva 


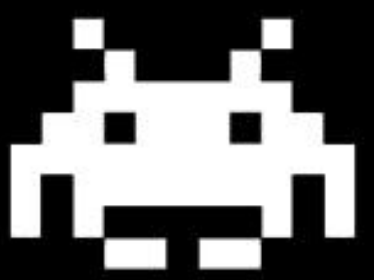

EFhE isł'T QWEF 